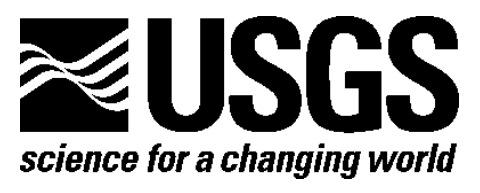

\title{
Obtaining Valid Geologic Models from 3-D Resistivity Inversion of Magnetotelluric Data at Pahute Mesa, Nevada
}

By Brian D. Rodriguez and Donald S. Sweetkind

Open-File Report 2015-1019

U.S. Department of the Interior

U.S. Geological Survey 


\section{U.S. Department of the Interior \\ SALLY JEWELL, Secretary}

\section{U.S. Geological Survey \\ Suzette M. Kimball, Acting Director}

U.S. Geological Survey, Reston, Virginia: 2015

For more information on the USGS—-the Federal source for science about the Earth,

its natural and living resources, natural hazards, and the environment-visit

http://www.usgs.gov or call 1-888-ASK-USGS (1-888-275-8747)

For an overview of USGS information products, including maps, imagery, and publications, visit http://www.usgs.gov/pubprod

To order this and other USGS information products, visit http://store.usgs.gov

Any use of trade, firm, or product names is for descriptive purposes only and does not imply endorsement by the U.S. Government.

Although this information product, for the most part, is in the public domain, it also may contain copyrighted materials as noted in the text. Permission to reproduce copyrighted items must be secured from the copyright owner.

Suggested citation:

Rodriguez, B.D., and Sweetkind, D.S., 2015, Obtaining valid geologic models from 3-D resistivity inversion of magnetotelluric data at Pahute Mesa, Nevada: U.S. Geological Survey Open-File Report 2015-1019, 104 p., http://dx.doi.org/10.3133/ofr20151019.

ISSN 2331-1258 (online) 


\section{Contents}

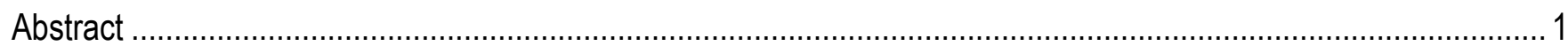

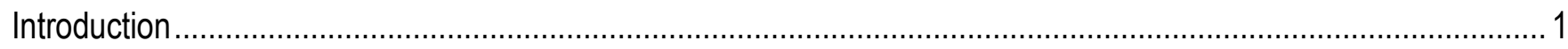

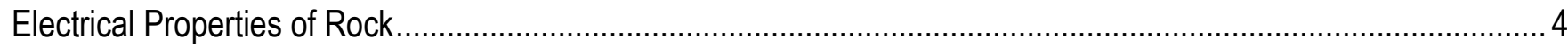

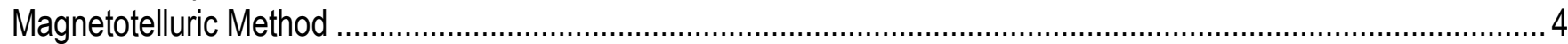

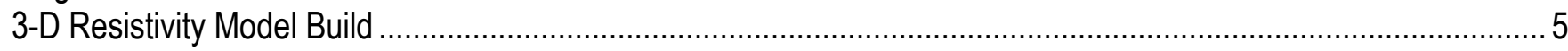

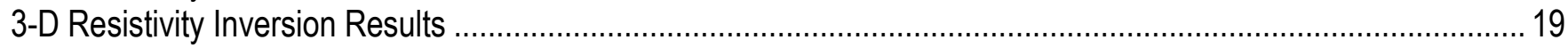

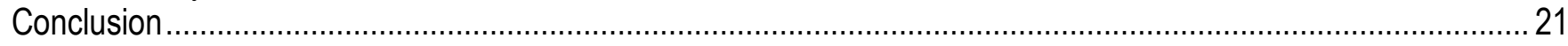

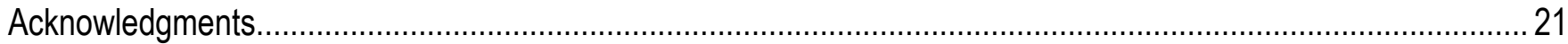

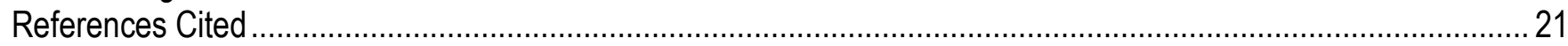

Appendix 1. Magnetotelluric Simulated and Computed Data....................................................................... 23

\section{Figures}

1. Pahute Mesa three-dimensional (3-D) geologic model area for the initial 3-D resistivity forward model ............... 3

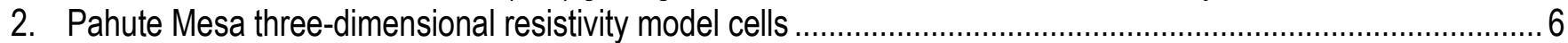

3. Pahute Mesa three-dimensional resistivity model profile A cross section .....................................................

4. Pahute Mesa three-dimensional resistivity model profile $B$ cross section ........................................................ 10

5. Pahute Mesa three-dimensional resistivity model profile $\mathrm{C}$ cross section .................................................... 11

6. Pahute Mesa three-dimensional resistivity model profile D cross section ...................................................... 12

7. Pahute Mesa three-dimensional resistivity model profile $\mathrm{E}$ cross section ..................................................... 13

8. Pahute Mesa three-dimensional resistivity model profile $\mathrm{F}$ cross section..................................................... 14

9. Pahute Mesa three-dimensional resistivity model profile $\mathrm{G}$ cross section ...................................................... 15

10. Pahute Mesa three-dimensional resistivity model profile $\mathrm{H}$ cross section ..................................................... 16

11. Pahute Mesa three-dimensional resistivity model profile I cross section ..................................................... 17

12. Selected Pahute Mesa three-dimensional resistivity forward model depth slices......................................... 18

13. Pahute Mesa three-dimensional resistivity inversion data along profile A .................................................... 24

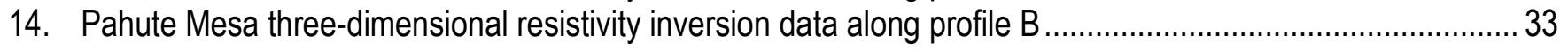

15. Pahute Mesa three-dimensional resistivity inversion data along profile $C$................................................ 42

16. Pahute Mesa three-dimensional resistivity inversion data along profile $D$..................................................... 51

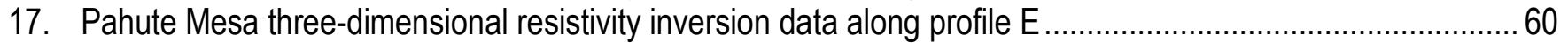

18. Pahute Mesa three-dimensional resistivity inversion data along profile $F$......................................................69

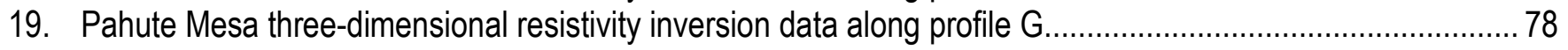

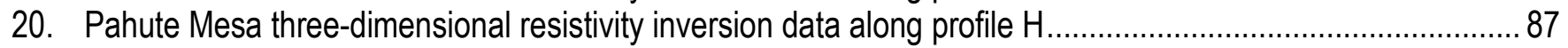

21. Pahute Mesa three-dimensional resistivity inversion data along profile I .....................................................96

\section{Table}

1. Hydrogeologic resistivities 


\section{Conversion Factors}

Inch/Pound to International System of Units

\begin{tabular}{|c|c|c|}
\hline Multiply & By & To obtain \\
\hline \multicolumn{3}{|c|}{ Length } \\
\hline foot (ft) & 0.3048 & meter (m) \\
\hline mile (mi) & 1.609 & kilometer (km) \\
\hline yard (yd) & 0.9144 & meter $(\mathrm{m})$ \\
\hline \multicolumn{3}{|c|}{ International System of Units to Inch/Pound } \\
\hline Multiply & By & To obtain \\
\hline \multicolumn{3}{|c|}{ Length } \\
\hline meter (m) & 3.281 & foot (ft) \\
\hline kilometer (km) & 0.6214 & mile (mi) \\
\hline meter (m) & 1.094 & yard (yd) \\
\hline
\end{tabular}

\section{Datum}

Vertical coordinate information is referenced to the 1980 Geodetic Reference System Spheroid.

Horizontal coordinate information is referenced to the North American Datum of 1983 (NAD 83).

Elevation, as used in this report, refers to distance above the vertical datum. 


\title{
Obtaining Valid Geologic Models from 3-D Resistivity Inversion of Magnetotelluric Data at Pahute Mesa, Nevada
}

\author{
By Brian D. Rodriguez and Donald S. Sweetkind
}

\begin{abstract}
We summarize the results of a three-dimensional (3-D) resistivity inversion simulation that we conducted with the intent of characterizing the subsurface 3-D distribution of volcanic composite units of Pahute Mesa, Nevada, without any a priori information on the actual 3-D distribution of the known subsurface geology. The 3-D methodology involved using a 3-D geologic model based on drillhole data and average electrical resistivities of the key hydrostratigraphic units at Pahute Mesa to create a 3-D resistivity forward ("known") model that depicted the subsurface resistivity structure expected for the input geologic configuration. The calculated magnetotelluric response of the modeled resistivity structure was then assumed to represent observed magnetotelluric data and was used as input into a 3-D resistivity inverse model that was allowed to iteratively estimate in 3-D without any a priori geologic information, in particular, the thickness and resistivity of the volcanic composite units. The resulting 3-D resistivity inversion simulation was compared to the "known" model and the results evaluated.

The 3-D inversion was generally able to reproduce the gross resistivity structure of the "known" model, but the simulated conductive volcanic composite unit horizons were often too shallow when compared to the "known" model. Additionally, the chosen computation parameters such as station spacing appear to have resulted in computational artifacts that are difficult to interpret but could potentially be removed with further refinements of the 3-D resistivity inversion modeling technique.
\end{abstract}

\section{Introduction}

Much of the Pahute Mesa, Nevada, area (fig. 1) within the Nevada National Security Site comprises volcanic composite units that contain a complex mix of lava flow aquifers and tuff confining units. Many of these composite units extend throughout and south of the primary nuclear testing area on Pahute Mesa. As situated, these units strongly influence the rate and direction of groundwater flow and radionuclide transport. Currently, these units are poorly resolved in terms of their hydrologic properties introducing large uncertainties into current flow and transport models. Keys and MacCary (1971) report that both permeability and resistivity decrease with grain size, and that clays tend to reduce the effective permeability of aquifers. Resolving the clay content, and thus permeability, of the volcanic composite confining units is critical in estimating confining unit properties for evaluating their bulk influence on the rate and direction of groundwater flow and radionuclide transport in current flow and transport models.

This study focused on testing a three-dimensional (3-D) magnetotelluric (resistivity) model simulation for characterizing and mapping the total thickness of volcanic composite units in Pahute Mesa. Detailed 3-D hydrostratigraphic framework models (Fenelon and others, 2010) that incorporate 
geologic data from the recently drilled Nevada National Security Site ER-EC series of holes were used as the geologic input to a 3-D resistivity forward model. Construction details of the 3-D

hydrostratigraphic model are described in Fenelon and others (2010). The calculated magnetotelluric response of the 3-D resistivity forward model was used as simulated observed magnetotelluric data for input into a homogeneous 3-D resistivity inverse model and allowed to iteratively estimate in 3-D the thickness and resistivity of the volcanic composite units.

The 3-D resistivity modeling results that follow were intended to serve as a proof of concept as to whether acquisition of 3-D magnetotelluric data will characterize and map the total thickness of volcanic composite units in Pahute Mesa. As such, this was essentially a feasibility study for reducing geologic uncertainty in the current framework model for Pahute Mesa. Reducing the uncertainty in the geologic and hydrostratigraphic framework models will also benefit strategies for defining good monitoring-well locations by having more accurate subsurface characterization of the groundwater barriers where drillhole information is sparse. 


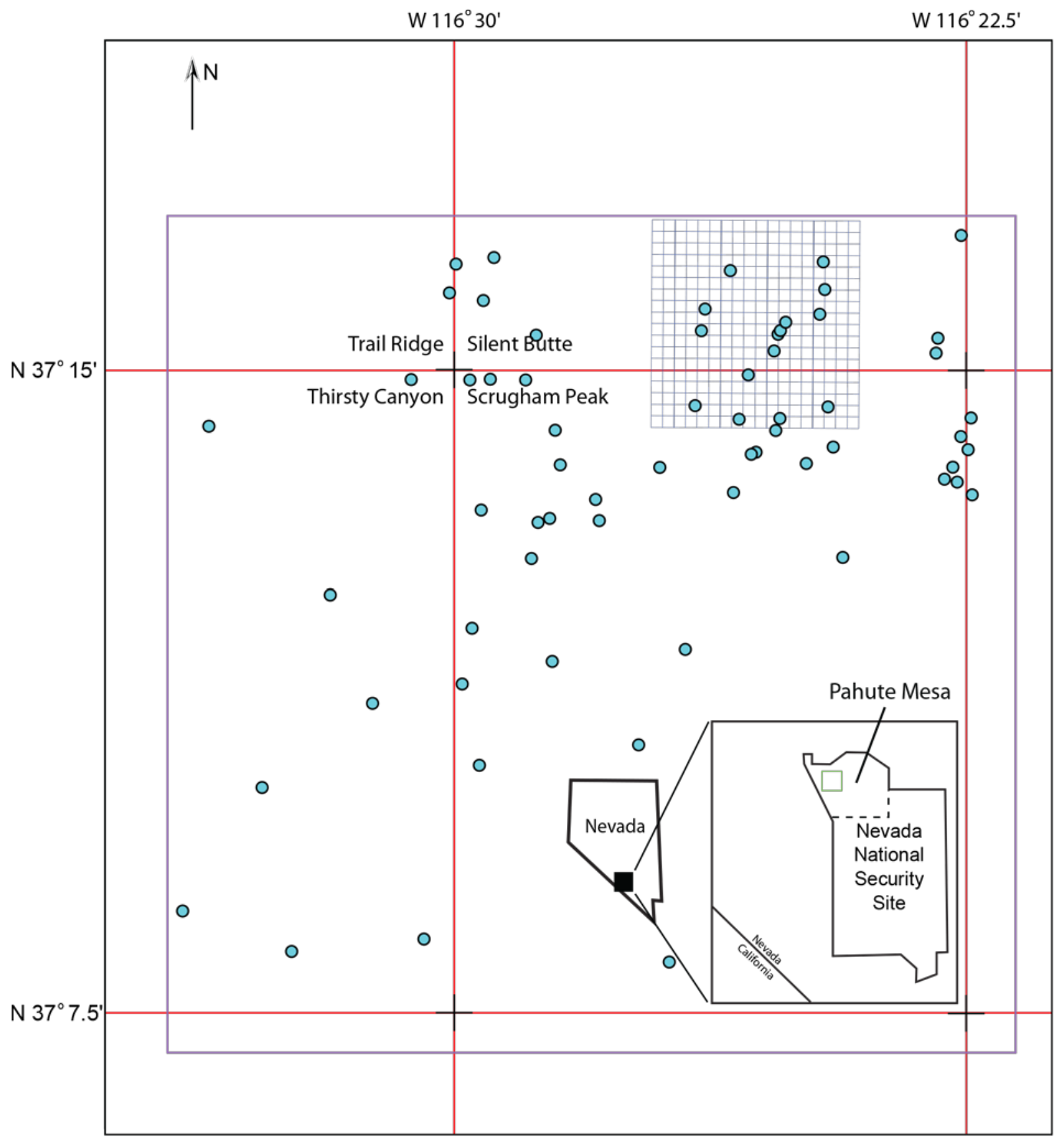

Figure 1. Pahute Mesa three-dimensional (3-D) geologic model area (purple outline box) for the initial 3-D resistivity forward model. Green outline box within index map inset is same as purple outline box. Blue line grids are final 3-D resistivity model cells. The 3-D inversion includes portions of the Silent Butte and Scrugham Peak U.S. Geological Survey quadrangles. Blue solid circles are boreholes used to construct the hydrogeologic model (Fenelon and others, 2010). Coordinates are referenced to the 1980 Geodetic Reference System spheroid and North American 1983 Continental United States (CONUS) datum. 


\section{Electrical Properties of Rock}

Electromagnetic geophysical methods detect variations in the electrical properties of rock units - in particular, electrical resistivity in units of ohm-meters (ohm-m) or its inverse, electrical conductivity, in units of Siemens per meter. Electrical resistivity can be correlated with geologic units on the surface and at depth by using lithologic and resistivity logs to provide a three-dimensional picture of subsurface geology. In the upper crust, the resistivities of geologic units largely depend upon their fluid content, pore-volume porosity, interconnected fracture porosity, and the presence of conductive minerals (such as clay, and less frequently, graphitic carbon and metallic minerals). Fluids in the pore spaces and fracture openings, especially saline fluids, can increase electrical conductivity in an otherwise electrically resistive rock matrix (Keller and Frischknecht, 1966; Hearst and Nelson, 1985; Keller, 1987; Palacky, 1987; Hallenburg, 1998). Although no one-to-one relation exists between lithology and resistivity, some general correlations can be made, even though resistivity variations exist within the same lithology sampled at different localities (Palacky, 1987) that may fall outside of the ranges presented below. It is common for altered volcanic rocks to contain replacement minerals that have resistivities only one-tenth as high as those of the surrounding rocks (Nelson and Anderson, 1992). Fine-grained sediments, such as clay-rich alluvium, clay-rich volcanic tuff, marine shales, and mudstones, are normally conductive and have resistivities of a few ohm-meters to tens of ohm-meters (Keller, 1987; Palacky, 1987). Metamorphic rocks (not containing graphite) and unaltered, unfractured igneous rocks are normally moderately to highly resistive (a few hundred to thousands of ohm-meters). Porous carbonate rocks with low fluid content and few impurities can have similarly high resistivities (Keller, 1987; Palacky, 1987). Fault zones may be moderately conductive (tens of ohm-meters) when composed of rocks fractured enough to have hosted fluid transport and consequent mineralogical alteration (Eberhart-Phillips and others, 1995). At greater depths, higher temperatures cause increased ion mobility, which increases fluid conductivity and, in turn, reduces the bulk resistivity (Hallenburg, 1998). Tables of electrical resistivity for a variety of rocks, minerals, and geological environments may be found in Palacky (1987) and Keller (1989).

\section{Magnetotelluric Method}

The magnetotelluric method is a passive ground-based electromagnetic geophysical technique that investigates the distribution of electrical resistivity (or its inverse, electrical conductivity) below the surface at depths of tens of meters to tens of kilometers (Vozoff, 1991). It does so by measuring time variations in the Earth's natural electric and magnetic fields. Worldwide lightning activity at frequencies of about 1 to 10,000 hertz and geomagnetic micropulsations at frequencies of 0.001 to 1 hertz provide the main source of signals used by the magnetotelluric method. Electromagnetic waves propagate vertically in the Earth because the very large contrast in the resistivity of the air and the Earth causes a vertical refraction of electromagnetic waves at the Earth's surface (Vozoff, 1972).

In the magnetotelluric method, the horizontal components of the electric and magnetic fields are recorded in two orthogonal directions; the vertical magnetic field component is also recorded. The resulting time-series signals are used to derive tensor apparent resistivities and phases after first converting them to complex cross-spectra by using fast Fourier transform techniques and least-squares, cross-spectral analysis (Bendat and Piersol, 1971) to solve for a tensor transfer function. If one assumes that the Earth consists of a two-input, two-output linear system in which the orthogonal magnetic fields are input and the orthogonal electric fields are output, then a transfer function can be calculated that relates the observed electric fields to the magnetic fields. 
For a two-dimensional Earth, in which subsurface resistivity is assumed to vary with depth and in one horizontal direction, the magnetotelluric fields can be decoupled into transverse electric and transverse magnetic modes. Two-dimensional resistivity modeling is generally computed to fit both modes. Before it is converted to apparent resistivity and phase, the tensor is normally rotated parallel to geologic strike. Subsurface geologic strike can be estimated from magnetotelluric data by determining the horizontal direction in which the magnetic field vector "tips" out of the horizontal plane (the tipper strike direction). When the geology satisfies the two-dimensional assumption, the magnetotelluric data for the transverse electric mode is assumed to represent the electric field oriented along geologic strike, while the data for the transverse magnetic mode is assumed to represent the electric field oriented across strike. The magnetotelluric method is well suited for studying complicated geological environments because the electric and magnetic field transfer functions are sensitive to both vertical and horizontal variations in resistivity. High-resolution shallow-subsurface characterization is possible for closely spaced magnetotelluric stations, but the resolution of the subsurface decreases for deeper measurements and for widely spaced stations. The method is thus capable of establishing whether the measured electric and magnetic field data are responding to subsurface rock bodies of effectively one, two, or three dimensions. An introduction to the magnetotelluric method and references for a more advanced understanding are contained in Dobrin and Savit (1988) and Vozoff (1991).

\section{3-D Resistivity Model Build}

The 3-D forward modeling algorithm of Mackie and others (1994) as implemented in GeoSystem's WinGLink (version 2.20.02) software was used to build the 3-D resistivity model. The 3D geologic model (Fenelon and others, 2010) that was used as input for the 3-D resistivity forward model covers much of Pahute Mesa (fig. 1). The 3-D geologic model grid covered an $18.5-\mathrm{km}$ by $18.0-$ $\mathrm{km}$ by $2.5-\mathrm{km}$ (XYZ) volume using $250-\mathrm{m}$ by $250-\mathrm{m}$ by $50-\mathrm{m}$ (XYZ) cells. The $3-\mathrm{D}$ inversion modeling program, WSINV3DMT (version 1.0.0), of Siripunvaraporn and others (2005) was used to invert the 3$\mathrm{D}$ resistivity model. However, the 3-D resistivity model computation requirements for a 3-D grid of magnetotelluric stations, even at 500-m station spacing, required nearly 700 gigabytes (GB) of computer memory to invert over 1,000 stations at 11 frequencies (from 0.01 to 1,000 hertz), which was far beyond the capabilities and time restraints of this study. A larger station spacing (to reduce the computation requirements) would have aliased key hydrostratigraphic units, so instead a smaller area, a $4.5-\mathrm{km}$ by $4.5-\mathrm{km}$ by $2.4-\mathrm{km}$ subset that contained the highest density of electrical resistivity borehole control points, was selected in the upper right quadrant of the original 3-D geologic model (figs. 1 and 2). This smaller model only required $6 \mathrm{~GB}$ of computer memory and about 1 month of computation time for five iterations of all eight real and imaginary diagonal and off-diagonal tensor elements over the 11 frequencies on a 3.5-giga-hertz (GHz) Intel Xeon W3690 processor, 64-bit workstation computer. 


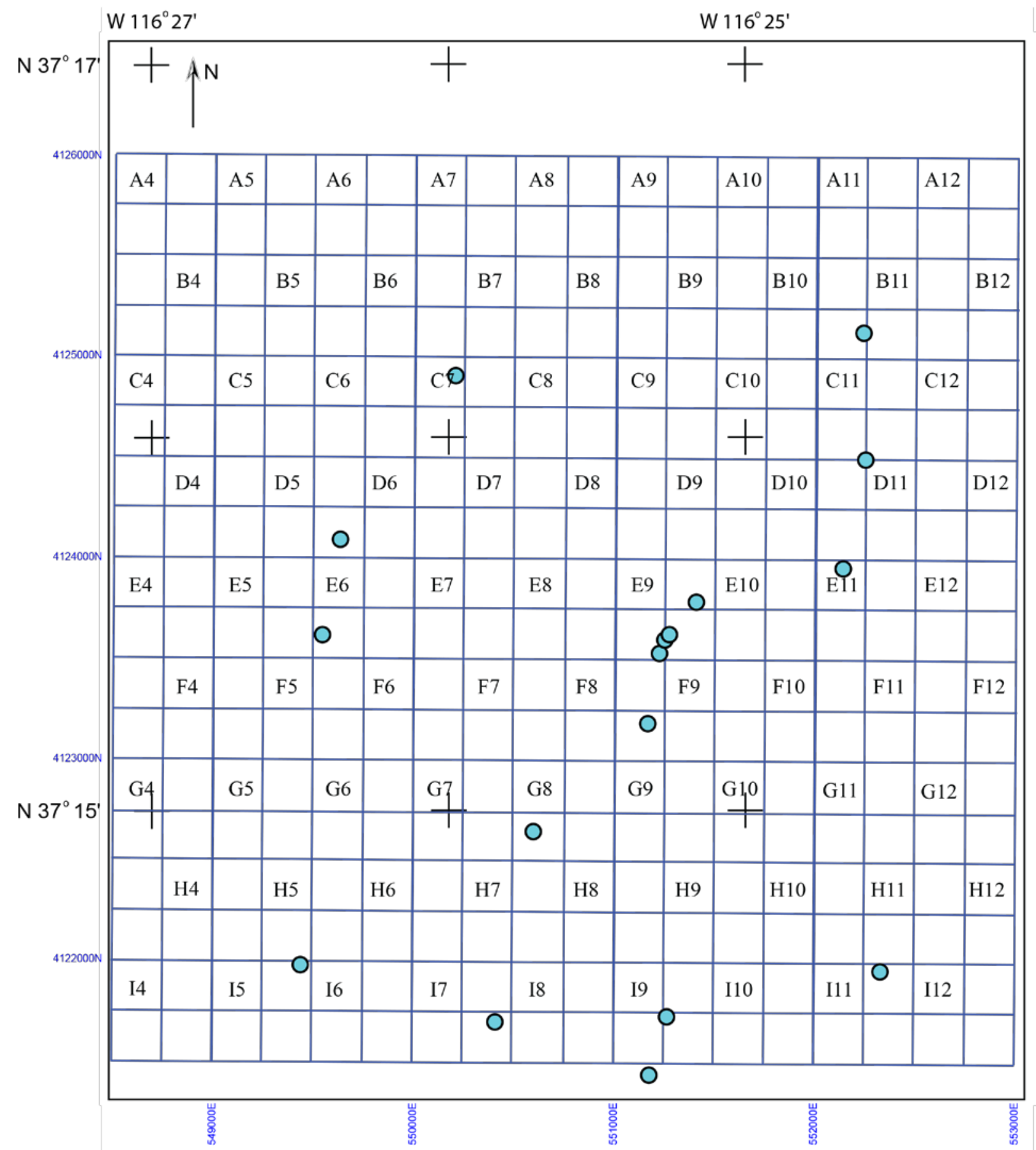

Figure 2. Pahute Mesa three-dimensional resistivity model cells (blue line grids). Black labels within cells are simulated magnetotelluric stations. Coordinates and symbols as in figure 1.

Building a valid 3-D resistivity forward model for this study required determining the average electrical resistivities of the key hydrostratigraphic units in the area (table 1). The average resistivities include both unsaturated and saturated units from logged geophysical boreholes in the area. The average elevation of the saturated-zone top in this area was confined to just below the Calico Hills composite unit top, a confining hydrostratigraphic unit in the area. It is a mixture of zeolitic tuffs and devitrified 
rhyolite lava flows. Three hydrostratigraphic units (TCVA, TMCM, and TMA) crop out within the resistivity model area, whose average unsaturated resistivities were about $250 \mathrm{ohm}-\mathrm{m}$.

Examination of well data from borehole resistivity logs in the area (table 1) shows that the upper five individual resistive hydrogeologic units are generally resistive units that overlay more conductive hydrogeologic units (the Calico Hills composite unit and the Crater Flat Group), which overlay the lower two resistive hydrogeologic units (pre-Crater Flat and Lower Carbonate aquifer). These three generalized resistivity layers (resistor, conductor, resistor) compose the primary magnetotelluric response of the resistivity data (appendix 1).

Nine east-west resistivity profile cross sections representing vertical slices through the 81 magnetotelluric stations (fig. 2) in the 3-D resistivity model are shown in figures 3-11. Figure 12 illustrates three depth slices of the three primary resistivity layers (resistor, conductor, resistor) from the 3-D resistivity "known" model. These profiles and depth slices (figs. 3-12) illustrate the three generalized resistivity layers (resistor, conductor, resistor) that are a function of the average resistivity of each hydrogeologic unit, in saturated and unsaturated conditions, and also zones of no geologic data (whose cells were assigned a resistivity of $375 \mathrm{ohm}-\mathrm{m}$, primarily below 2,400-m depth). The upper aquifer layers are generally resistive, although the upper part of the Calico Hills confining unit may also be resistive when it is unsaturated. The boundary between the conductive Calico Hills confining unit and the underlying conductive Crater Flat Group cannot be delineated because of their insufficient resistivity contrast. Also, instead of using simple layer-cake average resistivities for each hydrogeologic unit (table 1), additional hydrogeologic complexities were introduced that allowed further evaluation of the resolving power of the magnetotelluric method to mapping buried conductive or resistive volcanic units. These additional complexities included introducing additional conductive layers containing even higher conductivity zones to represent stronger confining properties and also introducing within the conductive layers anomalous resistive zones to represent lava flow aquifers within the composite volcanic unit to represent weaker confining properties. These complexities are variations from the original 3-D geologic model grid. Even with these complexities, the resistive and conductive structures in the 3-D forward resistivity model were smoothly connected in both the north-south and east-west directions as illustrated in figure 12. The calculated magnetotelluric response of the 3-D resistivity forward model was used as simulated observed magnetotelluric data for input into a 3-D resistivity inverse model whose initial model was a homogeneous volume of $400 \mathrm{ohm}-\mathrm{m}$ (based on the average borehole resistivity of the shallowest hydrogeologic horizon; TCVA in table 1), 3-D resistivity inverse model and allowed to iteratively estimate in 3-D the thickness and resistivity of the volcanic composite units. A synthetic relative noise level error of 2.5 percent of the impedance magnitude was applied to the synthetic data. The inversion results are described in the next section. 


\section{Table 1. Hydrogeologic resistivities.}

[System T, Tertiary; D- $€$, Devonian to Cambrian; HGU, hydrogeologic unit; RES, resistivity in ohm-meters from average induction log resistivity of hydrogeologic units from area boreholes (ER6-1, ER6-2, ER12-1, ER12-3, ER-19-1, ER-20-4, ER-20-5\#3, ER-20-6\#1, ER20-6\#2, ER-20-6\#3, ER-20-7, ER-EC-12, ER-EC-13, ER-EC-15, PM-1, PM-3); TCVA, tuffs of Thirsty Canyon Group; TMCM,

intracaldera rocks of the Rainier/Ammonia caldera; TMA, Timber Mountain aquifer; BA, Benham aquifer; TCA, Paintbrush Group; CH, Calico Hills composite confining unit; CF, Crater Flat Group; pre-CF, pre-Crater Flat (Belted Range and pre-Belted Range); LCA, Lower Carbonate aquifer]

\begin{tabular}{cccc}
\hline System & HGU1 & RES & Layer \\
\hline $\mathrm{T}$ & TCVA-dry & 375 & resistor \\
$\mathrm{T}$ & TMCM-dry & 207 & resistor \\
$\mathrm{T}$ & TMA-dry & 252 & resistor \\
$\mathrm{T}$ & BA-dry & 717 & resistor \\
$\mathrm{T}$ & TCA-dry & 221 & resistor \\
$\mathrm{T}$ & CH-saturated & 113 & conductor \\
$\mathrm{T}$ & CF-saturated & 64 & conductor \\
$\mathrm{T}$ & pre-CF-saturated & 198 & resistor \\
$\mathrm{D}-\epsilon$ & LCA-saturated & 4043 & resistor \\
\hline
\end{tabular}

${ }^{1} \mathrm{TMCM}$ and TMA are concurrent units. 


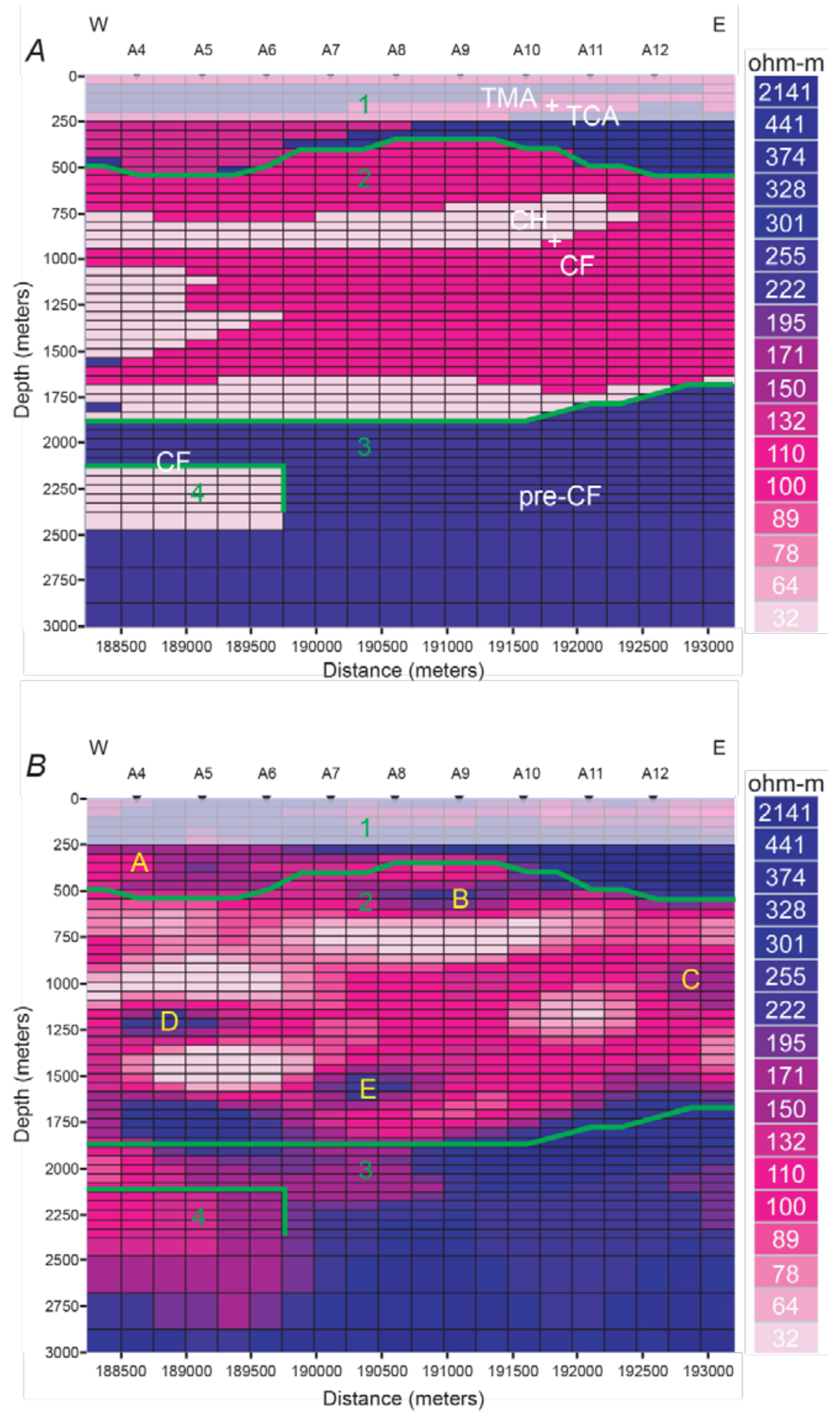

Figure 3. Pahute Mesa three-dimensional resistivity model profile A cross section. Black labels at top of cross section are simulated magnetotelluric stations (fig. 2). Vertical axis labels are negative depth in meters. Horizontal axis labels are position in meters. Green numbered labels are generalized resistivity zones discussed in the text. $A$. Forward model; abbreviated hydrogeologic unit labels as in table 1. $B$. Inversion model; yellow labels are resistivity model artifacts discussed in the text. 


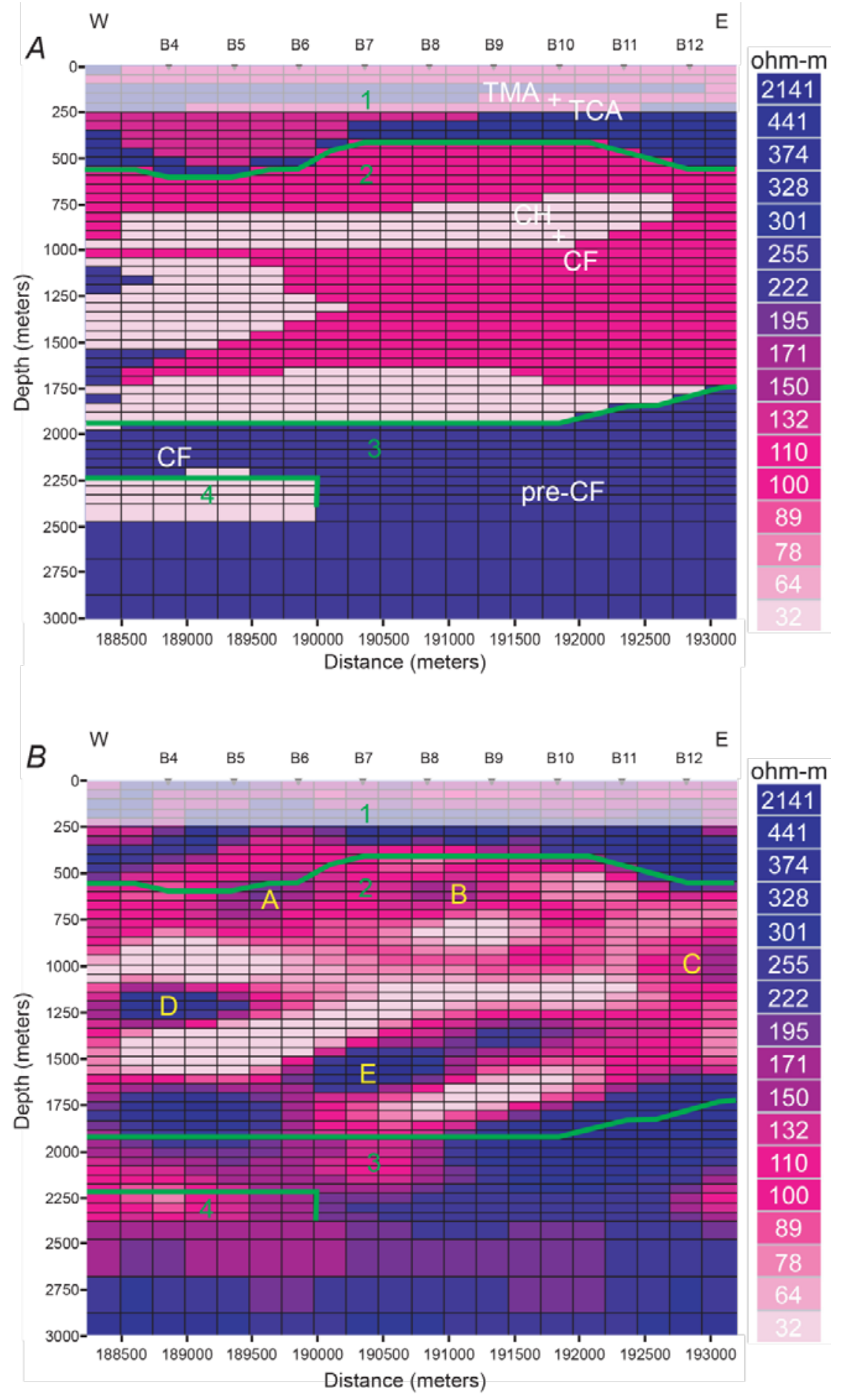

Figure 4. Pahute Mesa three-dimensional resistivity model profile B cross section. All other labels, symbols, axes, and lines are as in figure 3 . A. Forward model; $B$. inversion model. 


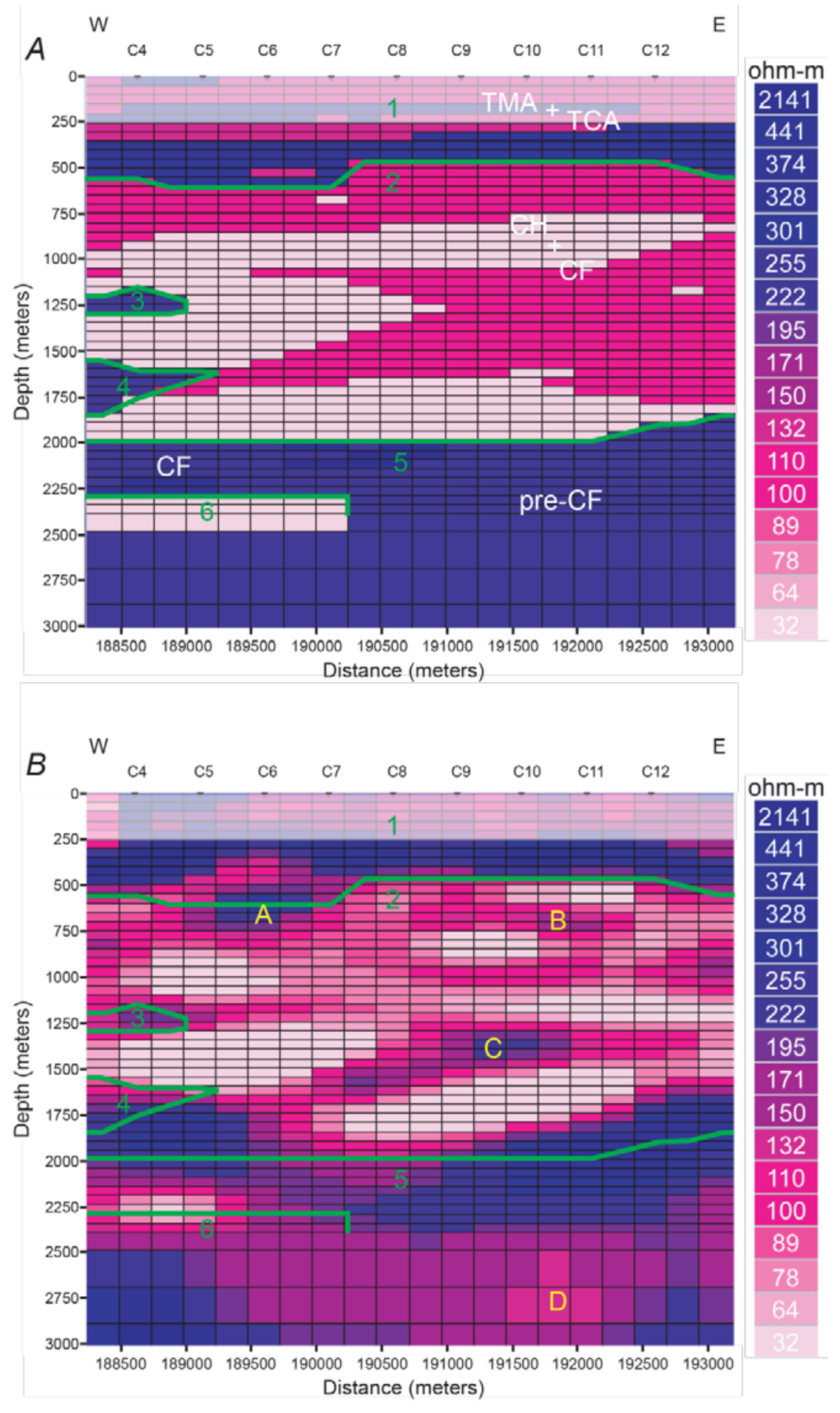

Figure 5. Pahute Mesa three-dimensional resistivity model profile $\mathrm{C}$ cross section. All other labels, symbols, axes, and lines are as in figure 3. A. Forward model; $B$. inversion model. 


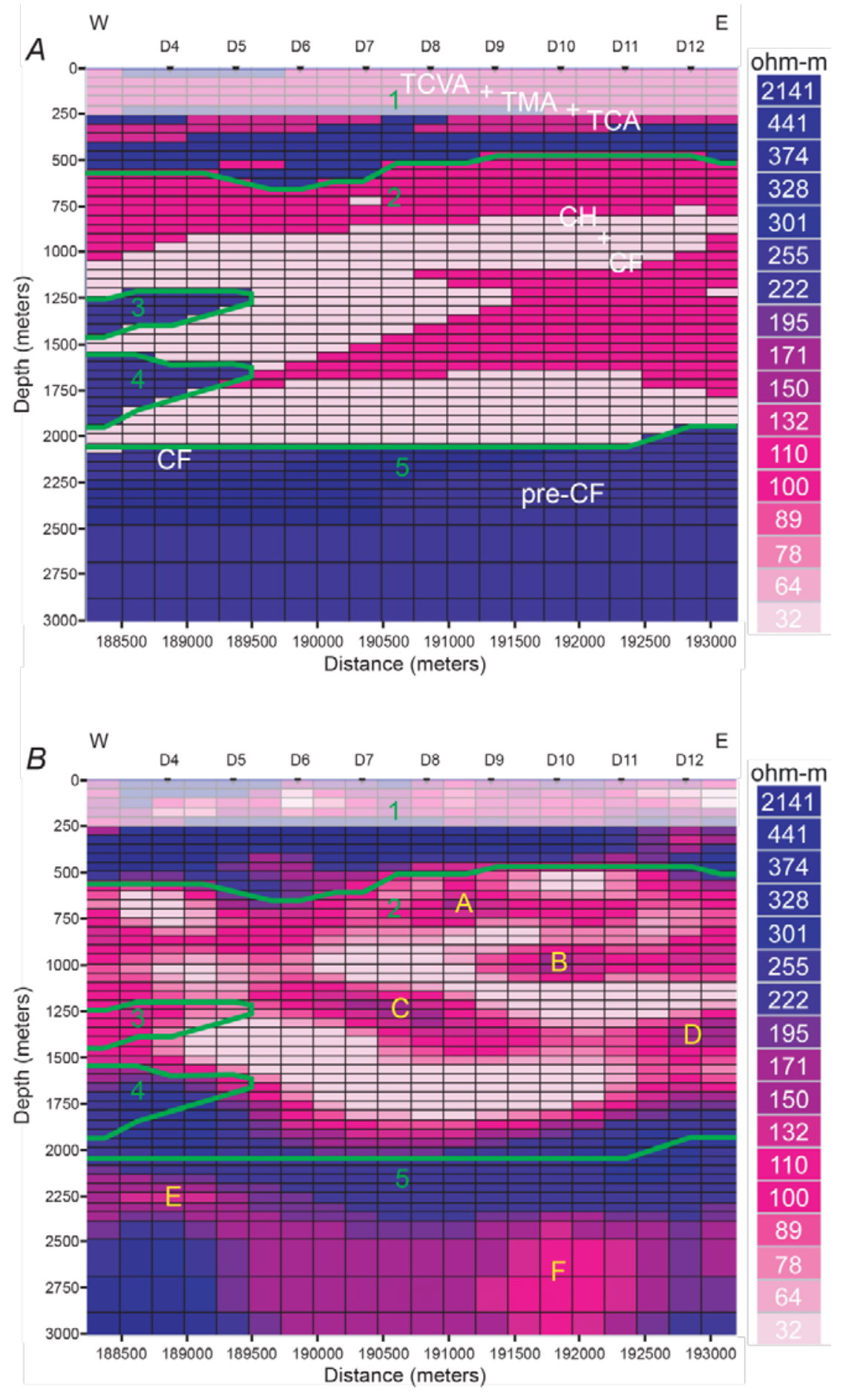

Figure 6. Pahute Mesa three-dimensional resistivity model profile D cross section. All other labels, symbols, axes, and lines are as in figure 3. A. Forward model; $B$. inversion model. 


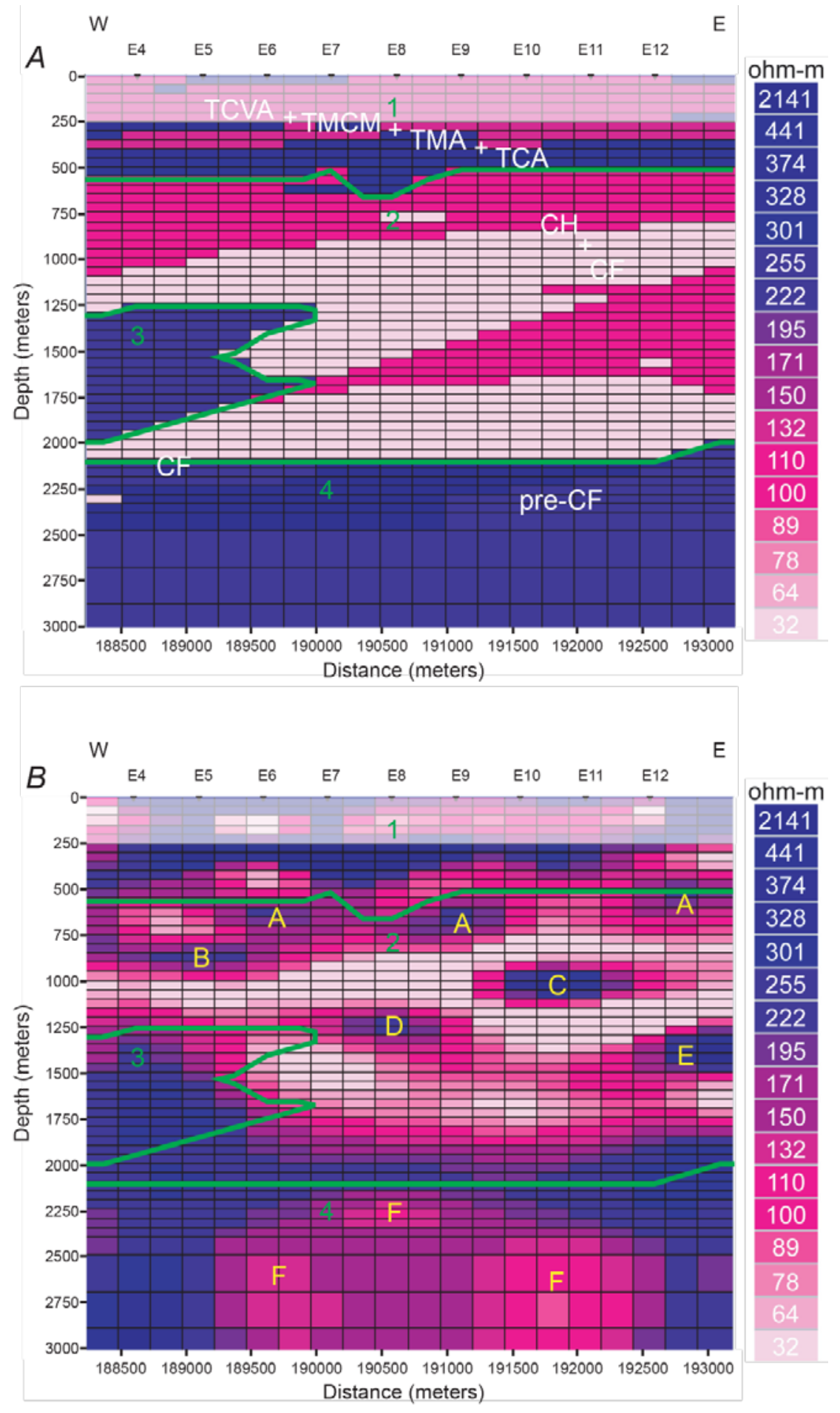

Figure 7. Pahute Mesa three-dimensional resistivity model profile $E$ cross section. All other labels, symbols, axes, and lines are as in figure 3. A. Forward model; $B$. inversion model. 


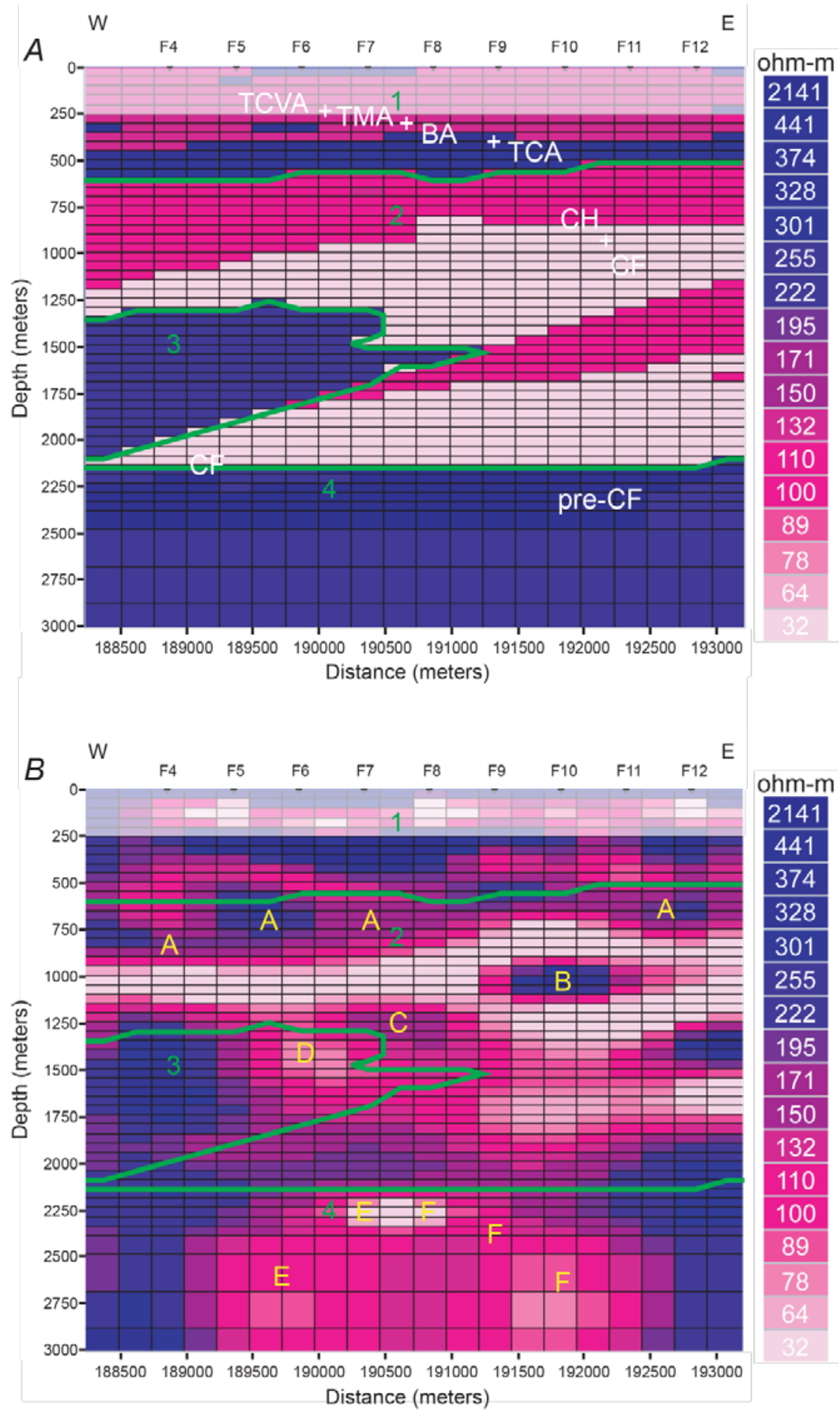

Figure 8. Pahute Mesa three-dimensional resistivity model profile $\mathrm{F}$ cross section. All other labels, symbols, axes, and lines are as in figure 3. $A$. Forward model; $B$. inversion model. 


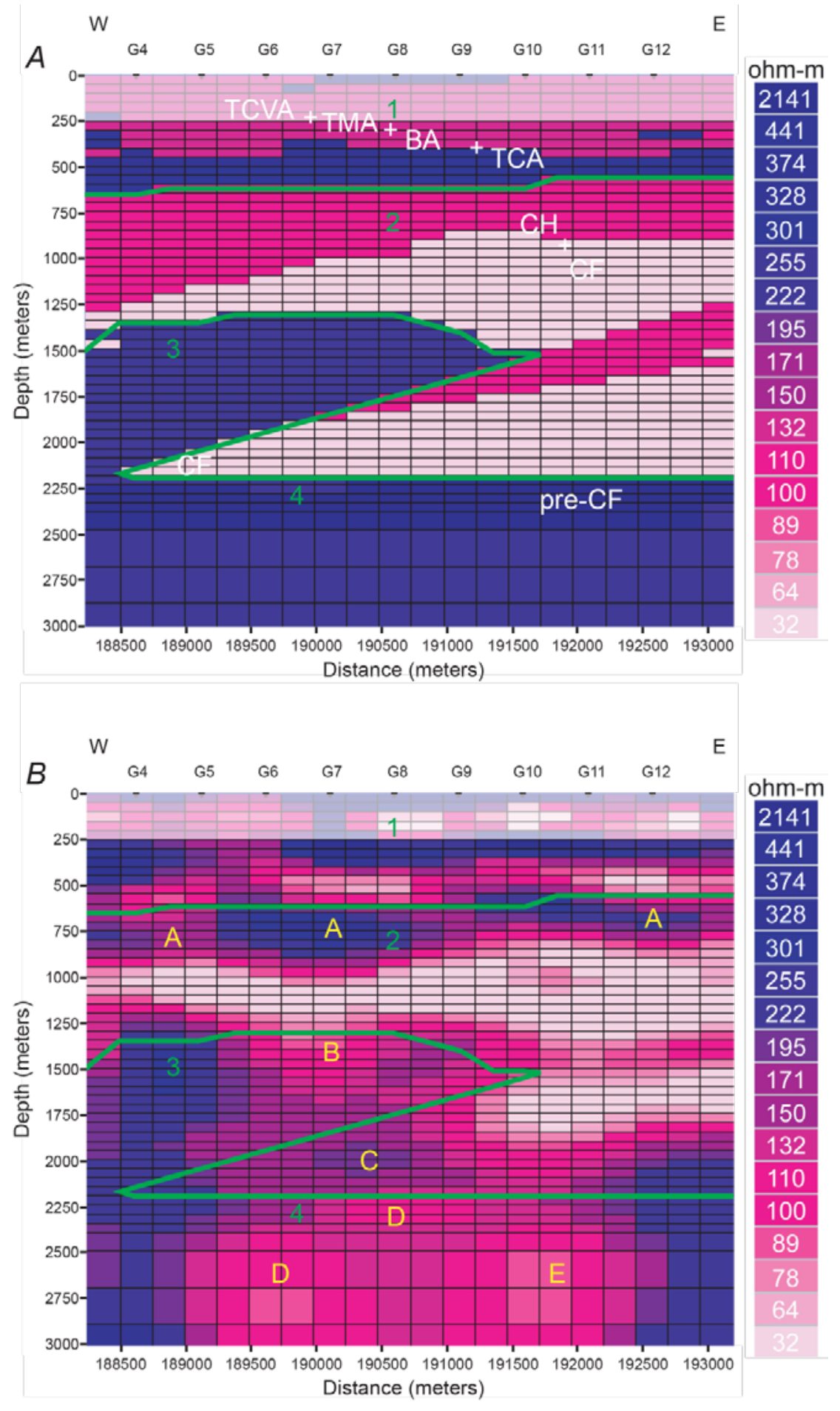

Figure 9. Pahute Mesa three-dimensional resistivity model profile $\mathrm{G}$ cross section. All other labels, symbols, axes, and lines are as in figure 3. A. Forward model; $B$. inversion model. 


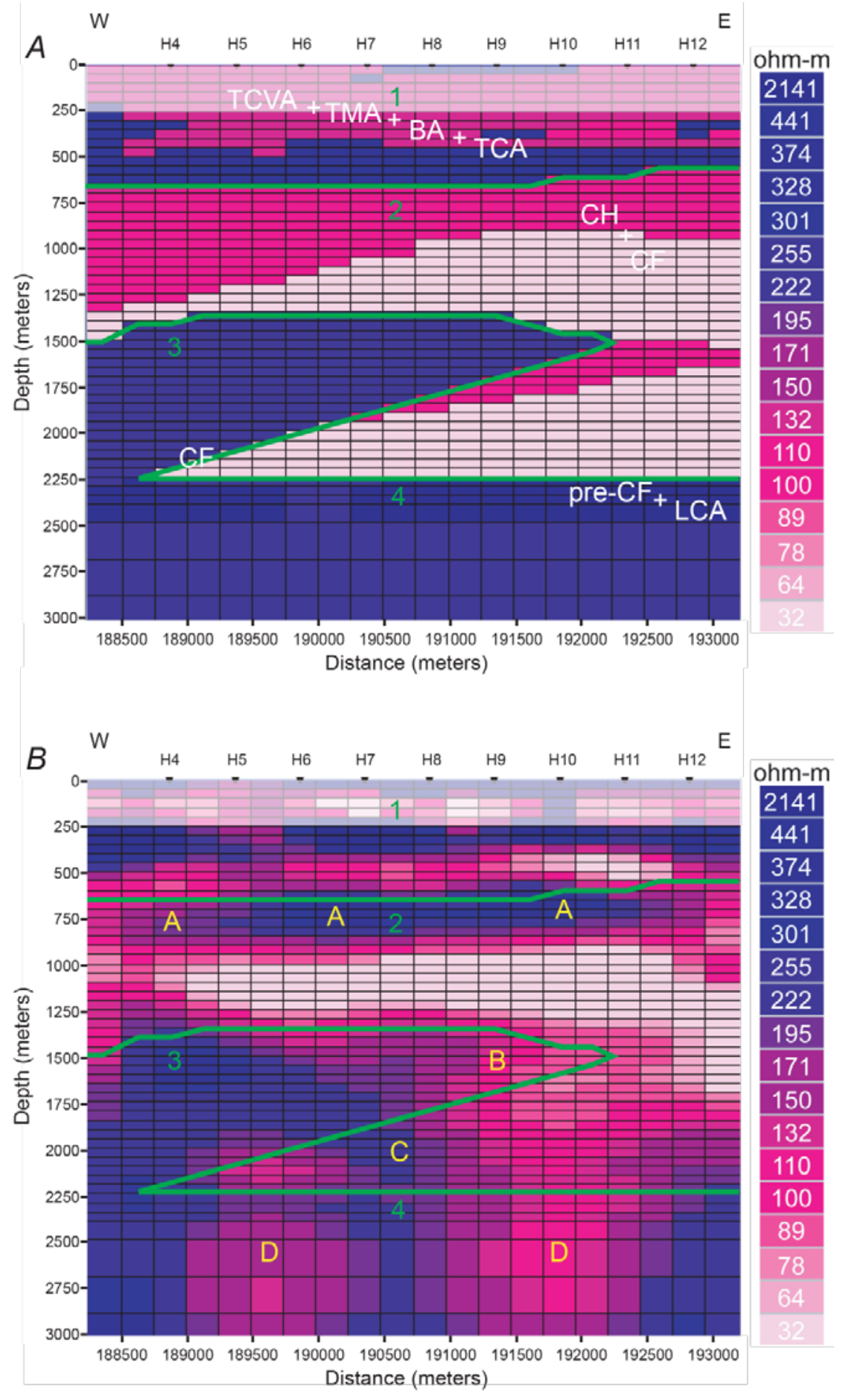

Figure 10. Pahute Mesa three-dimensional resistivity model profile $\mathrm{H}$ cross section. All other labels, symbols, axes, and lines are as in figure 3. A. Forward model; $B$. inversion model. 


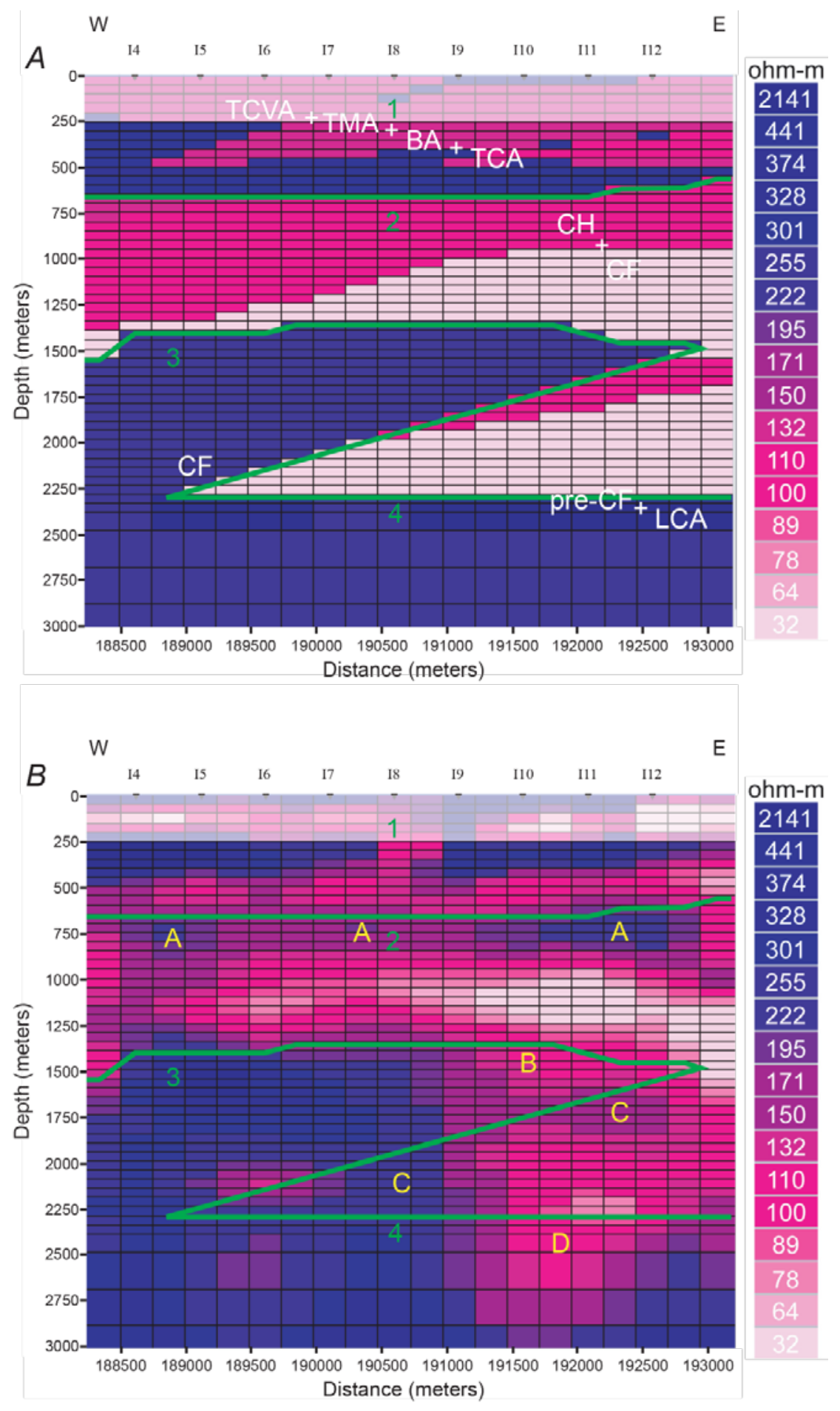

Figure 11. Pahute Mesa three-dimensional resistivity model profile I cross section. All other labels, symbols, axes, and lines are as in figure 3. A. Forward model; $B$. inversion model. 


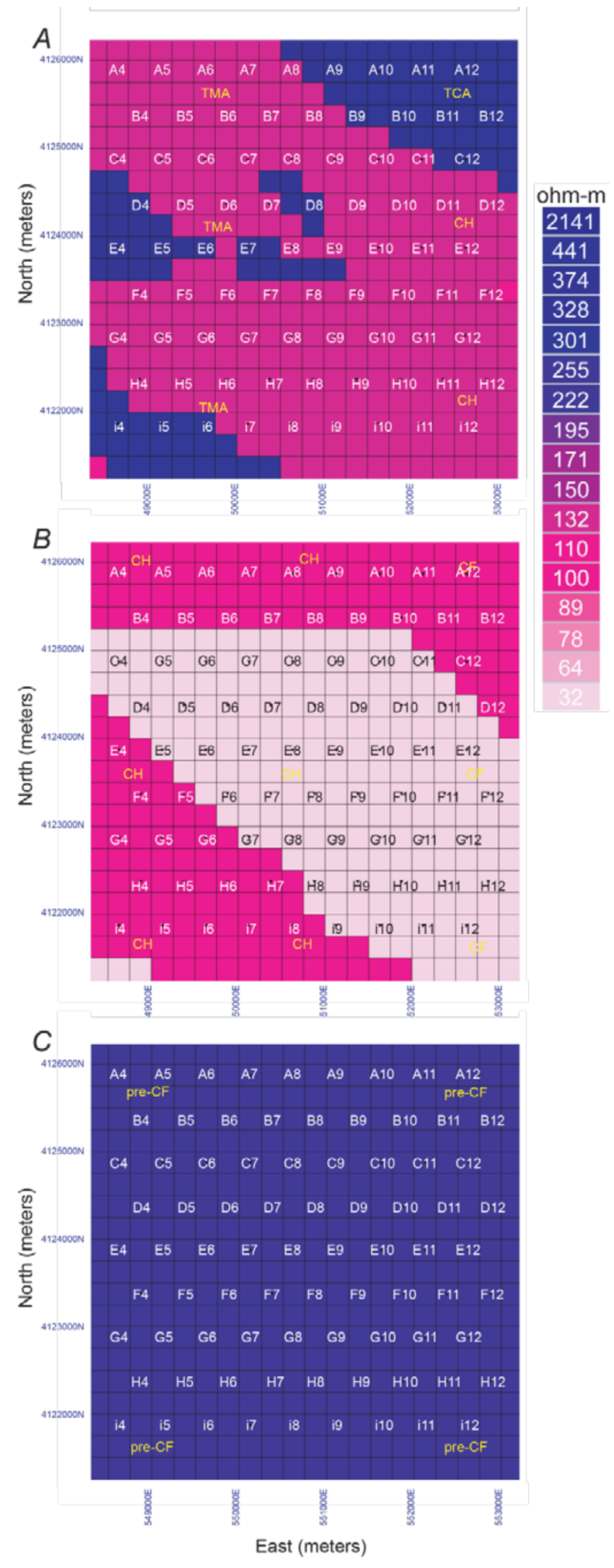

Figure 12. Selected Pahute Mesa threedimensional resistivity forward model depth slices. Abbreviations in yellow are as in table 1. A. Upper resistive (132 to 146 ohm-meters [ohm-m]) layer (250-m depth). B. Middle conductive (32 to $115 \mathrm{ohm}-$ $\mathrm{m})$ layer (1,000-m depth). C. Lower resistive (253 ohm-m) layer (2,500-m depth). 


\section{3-D Resistivity Inversion Results}

The default settings of WSINV3DMT (Siripunvaraporn and others, 2005) were used for all the inversion parameters, which resulted in a decrease in the total root mean square (RMS) error from 7.2180 for the initial homogeneous volume model to a total RMS of 0.5681 after five iterations (a reduction of over 1,000 percent). No further iterations were attempted, because of the time constraints for this study. The simulated observed magnetotelluric data and the computed magnetotelluric response of the fifth inversion iteration are shown in figures 13-21 (in appendix 1).

Profile cross section A (fig. 3) has four main resistivity layers, an upper resistive layer (zone 1 in fig. 3) comprising the lava flow aquifers and unsaturated Calico Hills composite unit, a middle conductive layer (zone 2) comprising the saturated Calico Hills composite unit and Crater Flat Group, a lower resistive layer (zone 3) comprising lava flow aquifers or welded-tuff aquifers of the Crater Flat Group and pre-Crater Flat units, and a lower conductive zone (zone 4) comprising conductive confining units within the Crater Flat Group. Zone 4 provides an evaluation of the resolving power of the magnetotelluric method for the deepest buried target conductors in this area. Figure $3 A$ illustrates the resistivity forward model used to calculate the simulated observed magnetotelluric data that was used as input into the 3-D resistivity inversion whose initial model was a $400-\mathrm{ohm}-\mathrm{m}$ homogeneous volume. Figure $3 B$ illustrates the 3-D resistivity inversion result. The upper $250-\mathrm{m}$ depth is obscured to illustrate that the highest frequency calculated in this inversion (1,000 hertz) is not sensitive to the resistivity above 250-m depth. Below 250-m depth, the inversion correctly resolved most of the upper resistive layer except near model artifacts A and B (fig. $3 B$ ), where the inversion placed conductive cells too shallow in the section, and also near magnetotelluric station A9, where the inversion placed resistive artifact B within the conductive Calico Hills composite unit. These model artifacts may be due to regularization. The resistive artifacts $\mathrm{C}, \mathrm{D}$, and $\mathrm{E}$ found between magnetotelluric stations within the conductive Calico Hills and Crater Flat units may also be due to regularization. Otherwise, the inversion resolved much of the middle conductive layer including the shallower conductive zones within the layer that represents stronger confining properties. The inversion also placed the lower resistive layer (zone 3) shallower than the forward ("known") model by nearly 20 percent of the burial depth. The inversion also placed the deeper conductive layer (zone 4) shallower than the "known" model and did not recover the "known" resistivity of this deeper conductive layer.

Profile cross section B (fig. 4) also has four main resistivity layers (zones 1 to 4) similar to Profile A. Below 250-m depth, the inversion correctly resolved most of the upper resistive layer except near model artifacts A and B (fig. 4B), where the inversion placed conductive cells too shallow (above the resistive artifacts A and B). Resistive artifacts A and B may be due to regularization. Resistive artifact $\mathrm{C}$ on the profile edge may also be due to regularization, but otherwise, the inversion closely resolved the upper boundary of the middle conductive layer below station B12. Resistive artifact D appears to be caused by an off-profile synthetic resistor (west of station B4, between 1,000- and 1,250$\mathrm{m}$ depth in fig. 4A). Resistive artifact $\mathrm{E}$ may be due to regularization. The inversion resolved much of the middle conductive layer including some of the shallower and deeper conductive zones within the layer that represent stronger confining properties. The inversion also placed the lower resistive layer (zone 3) shallower than the "known" model for the western (stations B4 and B5) and eastern (stations B9 to B12) ends of the profile. The inversion also placed the deeper conductive layer (zone 4) shallower than the "known" model and did not recover the "known" resistivity of this deeper conductive layer.

Profile cross section C (fig. 5) has six main resistivity layers (zones 1 to 6). Below 250-m depth, the inversion correctly resolved most of the upper resistive layer except near resistive artifact A beneath station C6 (fig. 5B), where the inversion placed conductive cells too shallow (above the resistive artifact 
A). Resistive artifacts A, B, and C may be due to regularization. The inversion resolved much of the middle conductive layer including some of the shallower and deeper conductive zones within the layer. The inversion also closely resolved resistive zone 3 . The top of resistivity zone 4 was partly recovered, but its bottom was obscured where the inversion placed the lower resistive layer (zone 5) shallower than the "known" model. The inversion also placed the deeper conductive layer (zone 6) shallower than the "known" model and did not recover the "known" resistivity of this deeper conductive layer. The inversion also placed conductive artifact D within resistive layer 5.

Profile cross section D (fig. 6) has five main resistivity layers (zones 1 to 5). Below 250-m depth, the inversion correctly resolved most of the upper resistive layer. Resistive artifacts A, B, C, and $\mathrm{D}$ may be due to regularization. The inversion partly resolves resistive zone 3 by retaining a more resistive zone between a conductor above and below it. The top of resistivity zone 4 was recovered but its bottom was obscured where the inversion placed the lower resistive layer (zone 5) shallower than the "known" model. The inversion also placed conductive artifacts $\mathrm{E}$ and $\mathrm{F}$ within resistive layer 5.

Profile cross section E (fig. 7) has four main resistivity layers (zones 1 to 4). Below 250-m depth, the inversion correctly resolved most of the upper resistive layer except near resistive artifacts A, where the inversion placed conductive cells too shallow (above resistive artifacts A). Resistive artifacts $\mathrm{A}, \mathrm{B}, \mathrm{C}$, and $\mathrm{D}$ may be due to regularization. The inversion mostly resolves resistive zone 3 except for the upper resistive limb and the bottom of the lower limb where the inversion placed the top of resistivity zone 4 too shallow. The inversion also placed conductive artifacts $\mathrm{F}$ within resistive layer 4.

Profile cross section F (fig. 8) has four main resistivity layers (zones 1 to 4). Below 250-m depth, the inversion correctly resolved much of the upper resistive layer except near resistive artifacts A, where the inversion placed conductive cells too shallow (above resistive artifacts A). Resistive artifacts $\mathrm{A}, \mathrm{B}$, and $\mathrm{C}$ may be due to regularization. Conductive artifact D occurs where the inversion senses the resistive zone 3 within the zone 2 conductive slab, but the inversion pushes the top of resistive zone 3 too deep, which also pushes the top of the conductive zone 2 slab too deep, resulting in conductive artifacts E beneath stations F6 and F7. The inversion also placed conductive artifacts F beneath stations $\mathrm{F} 8$, F9, and F10 within resistive layer 4.

Profile cross section G (fig. 9) has four main resistivity layers (zones 1 to 4). Below 250-m depth, the inversion correctly resolved much of the upper resistive layer except near resistive artifacts A, where the inversion placed conductive cells too shallow (above resistive artifacts A). Conductive artifact $\mathrm{B}$, resistive artifact $\mathrm{C}$, and conductive artifacts $\mathrm{D}$ appear where the inversion senses the resistive zone 3 within the zone 2 conductive slab. However, the inversion pushes the top of resistive zone 3 too deep where it also pushes the top of the conductive zone 2 slab too deep, resulting in conductive artifacts D beneath stations G6, G7, G8, and G9. The inversion also placed conductive artifact E beneath stations G10 and G11 within resistive layer 4. The inversion was more successful on the eastern half of the profile beneath stations G11 and G12 resolving the middle conductive patterns of zone 2, although it also made the top of resistive layer 4 too shallow.

Profile cross section H (fig. 10) has four main resistivity layers (zones 1 to 4). Below 250-m depth, the inversion correctly resolved much of the upper resistive layer except near resistive artifacts A, where the inversion placed conductive cells too shallow (above resistive artifacts A). Conductive artifact $B$, resistive artifact $C$, and conductive artifacts $D$ are where the inversion senses the resistive zone 3 and the zone 2 conductive slab beneath. However, the inversion pushes the top of resistive zone 3 too deep, where it also pushes the top of the conductive zone 2 slab too deep, resulting in conductive artifacts D beneath stations $\mathrm{H} 5, \mathrm{H} 6, \mathrm{H} 9$, and $\mathrm{H} 10$.

Profile cross section I (fig. 11) has four main resistivity layers (zones 1 to 4). Below 250-m depth, the inversion correctly resolved much of the upper resistive layer except near resistive artifacts A, 
where the inversion placed conductive cells too shallow (above resistive artifacts A). Conductive artifact $\mathrm{B}$, resistive artifacts $\mathrm{C}$, and conductive artifact $\mathrm{D}$ are where the inversion senses the resistive zone 3 and the zone 2 conductive slab beneath. However, the inversion pushes the top of resistive zone 3 too deep where it also pushes the top of the conductive zone 2 slab too deep, resulting in conductive artifact D beneath stations I10 and I11.

\section{Conclusion}

Both permeability and resistivity decrease with grain size, and clays tend to reduce the effective permeability of aquifers. Resolving the clay content, and thus permeability, of the volcanic composite confining units at Pahute Mesa, Nevada, is critical in estimating confining unit properties for evaluating their bulk influence on the rate and direction of groundwater flow and radionuclide transport in current flow and transport models. The 3-D resistivity inversion, whose initial model was a 400-ohm-m, homogeneous volume, used simulated magnetotelluric data generated from a 3-D resistivity forward model built using 3-D hydrostratigraphic framework models and available well data. The 3-D inversion results show some promise of recovering the resistivity and thickness of the buried volcanic composite confining units, but numerous model uncertainties and artifacts exist. The modeling process itself is time-consuming and computationally intensive, such that additional refinement of the modeling technique, a necessary step prior to any field-data collection, would be time-intensive.

We do not currently recommend collecting new magnetotelluric data in Pahute Mesa without further testing 3-D resistivity inversion-code parameters. Future study should focus on additional 3-D resistivity model simulations that incorporate 3-D inversion smoothness parameter adjustments and smaller station spacing to achieve a closer agreement to the characterization and mapping of the total thickness of the volcanic composite units in the "known" model. To determine with certainty whether 3D magnetotelluric modeling can really resolve the resistivity and thickness of the buried volcanic composite confining units, further 3-D inversions should be conducted by building a synthetic model using the main resistive and conductive features of the inversion but not incorporating the smaller scale resistive and conductive bodies used in the original "known" model.

\section{Acknowledgments}

We thank USGS reviewers Paul Bedrosian and Beth Burton for providing constructive reviews and helpful comments for this report. This work was supported by the Mineral Resources Program of the USGS.

\section{References Cited}

Bendat, J.S., and Piersol, A.G., 1971, Random data-Analysis and measurement procedures: New York, Wiley Interscience, $407 \mathrm{p}$.

Dobrin, M.D., and Savit, C.H., 1988, Introduction to geophysical prospecting (4th ed.): New York, McGraw-Hill, 867 p.

Eberhart-Phillips, Donna, Stanley, W.D., Rodriguez, B.D., and Lutter, W.J., 1995, Surface seismic and electrical methods to detect fluids related to faulting: Journal of Geophysical Research, v. 100, no. B7, p. 12919-12936. (Also available at http://onlinelibrary.wiley.com/doi/10.1029/94JB03256/pdf.)

Fenelon, J.M., Sweetkind, D.S., and Laczniak, R.J., 2010, Groundwater flow systems at the Nevada

Test Site, Nevada - A synthesis of potentiometric contours, hydrostratigraphy, and geologic 
structures: U.S. Geological Survey Professional Paper 1771, 54 p., 6 pls. (Also available at http://pubs.usgs.gov/pp/1771/.)

Hallenburg, J.K., 1998, Non-hydrocarbon methods of geophysical formation evaluation: Boca Raton, Fla., Lewis Publishers, 265 p.

Hearst, J.R., and Nelson, P.H., 1985, Well logging for physical properties: New York, McGraw-Hill, $571 \mathrm{p}$.

Keller, G.V., 1987, Rock and mineral properties, in Nabighian, M.N., ed., Electromagnetic methods in applied geophysics theory: Tulsa, Okla., Society of Exploration Geophysicists, v. 1, p. 13-51.

Keller, G.V., 1989, Electrical properties, in Carmichael, R.S., ed., Practical handbook of physical properties of rocks and minerals: Boca Raton, Fla., CRC Press, p. 359-427.

Keller, G.V., and Frischknecht, F.C., 1966, Electrical methods in geophysical prospecting: Oxford, Pergamon Press, Inc., 519 p.

Keys, W.S., and MacCary, L.M., 1971, Application of borehole geophysics to water-resources investigations: U.S. Geological Survey Techniques of Water-Resources Investigations, book 2, chap. E1, 126 p. (Also available at http://pubs.usgs.gov/twri/twri2-e1/pdf/TWRI2-E1A.pdf.)

Mackie, R.L., Smith, J.T., and Madden, T.R., 1994, Three-dimensional electromagnetic modeling using finite difference equations-The magnetotelluric example: Radio Science, v. 29, p. 923-935. (Also available at http://onlinelibrary.wiley.com/doi/10.1029/94RS00326/pdf.)

Nelson, P.H., and Anderson, L.A., 1992, Physical properties of ash flow tuff from Yucca Mountain, Nevada: Journal of Geophysical Research, v. 97, no. B5, p. 823-841. (Also available at http://onlinelibrary.wiley.com/doi/10.1029/92JB00350/pdf.)

Palacky, G.J., 1987, Resistivity characteristics of geologic targets, in Nabighian, M.N., ed., Electromagnetic methods in applied geophysics: Tulsa, Okla., Society of Exploration Geophysicists, v. 1, p. 53-129.

Siripunvaraporn, W., Egbert, G., Lenbury, Y., and Uyeshima, M., 2005, Three-dimensional magnetotelluric inversion - Data-space method: Physics of the Earth and Planetary Interiors, v. 150, p. 3-14. (Also available at http://www.sciencedirect.com/science/article/pii/S0031920104003590\#.)

Vozoff, Keeva, 1972, The magnetotelluric method in the exploration of sedimentary basins: Geophysics, v. 37, p. 980-141. (Also available at http://library.seg.org/doi/abs/10.1190/1.1440255.) Vozoff, Keeva, 1991, The magnetotelluric method, in Nabighian, M.N., Electromagnetic methods in applied geophysics: Tulsa, Okla., Society of Exploration Geophysicists, v. 2, pt. B, p. 641-711. (Also available at http://library.seg.org/doi/abs/10.1190/1.9781560802686.ch8.) 


\section{Appendix 1. Magnetotelluric Simulated and Computed Data}

The 3-D forward modeling algorithm of Mackie and others (1994) as implemented in GeoSystem's WinGLink (version 2.20.02) software was used to calculate the simulated observed apparent resistivity data. The 3-D inversion modeling program, WSINV3DMT (version 1.0.0), of Siripunvaraporn and others (2005) was used to invert the synthetic data for a 3-D resistivity model. The data diagrams below illustrate the 3 -D resistivity inversion computed data and simulated observed data for each magnetotelluric station along the model profile. 

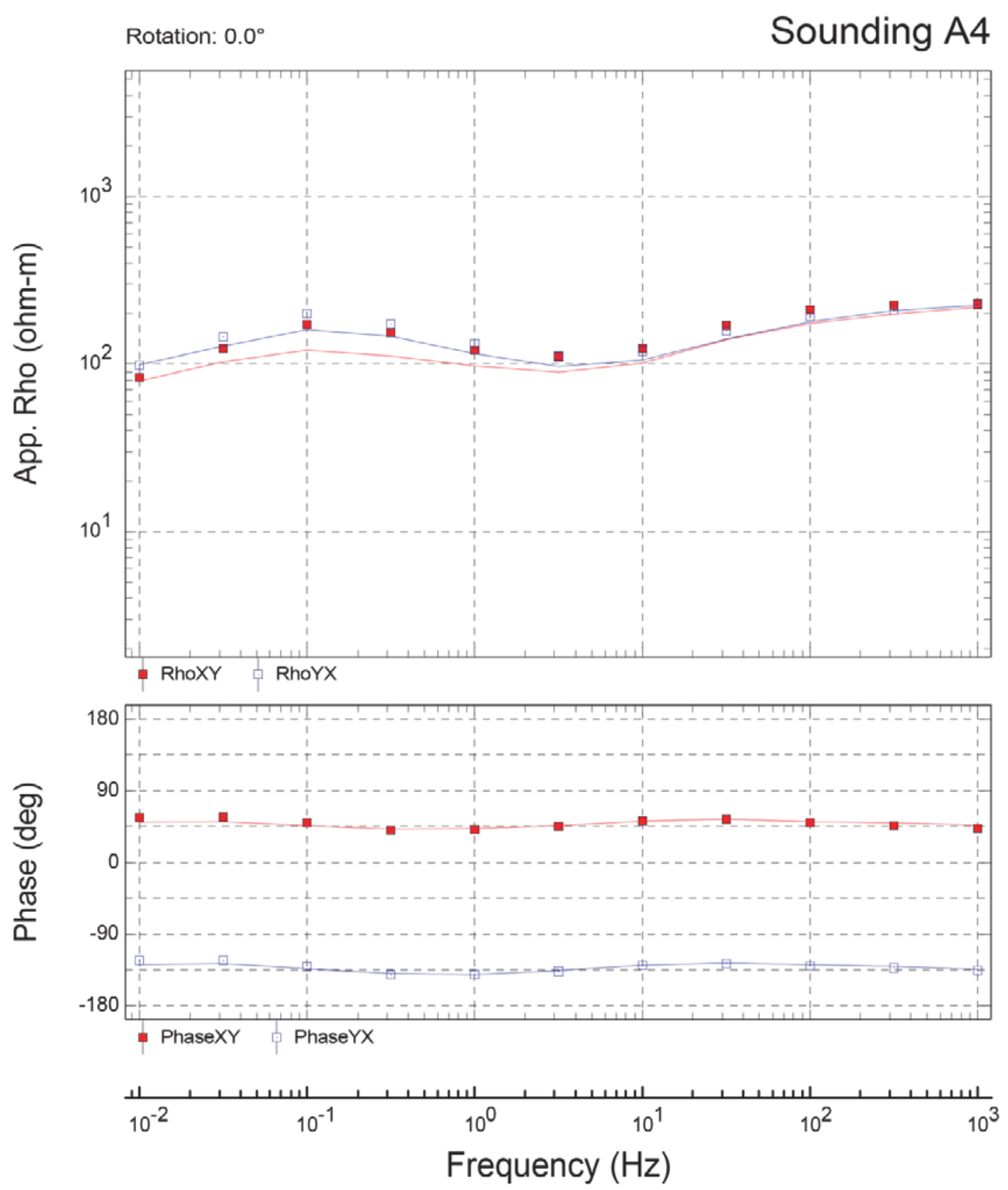

Figure 13. Soundings A4-A12. Pahute Mesa three-dimensional (3-D) resistivity inversion data along profile $A$. App Rho is apparent resistivity. Phase is in degrees. Red and blue lines are the 3-D computed $X Y$ and $Y X$ inversion curves, respectively. Red and blue square symbols are the 3-D simulated observed $X Y$ and $Y X$ data, respectively. 


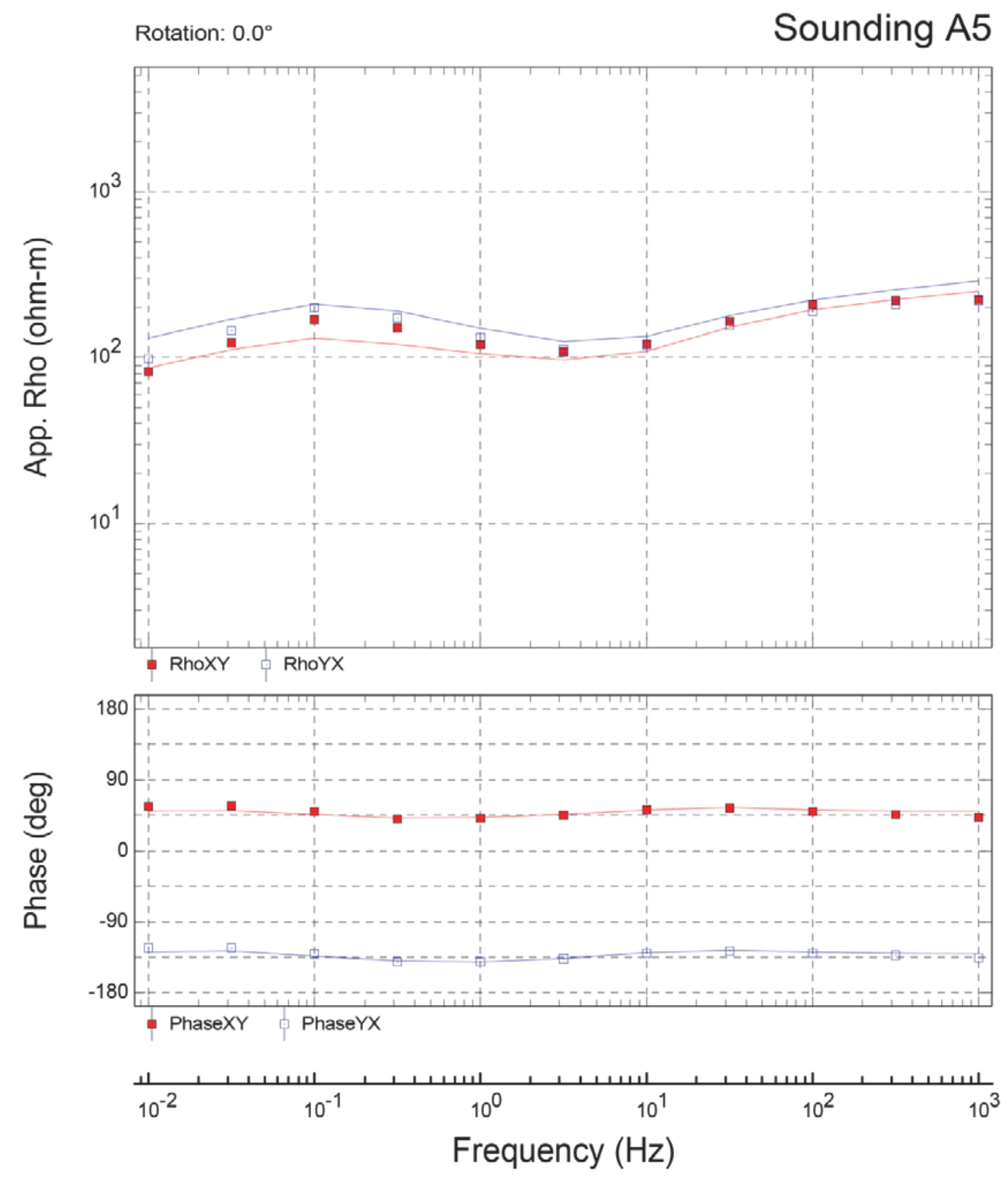




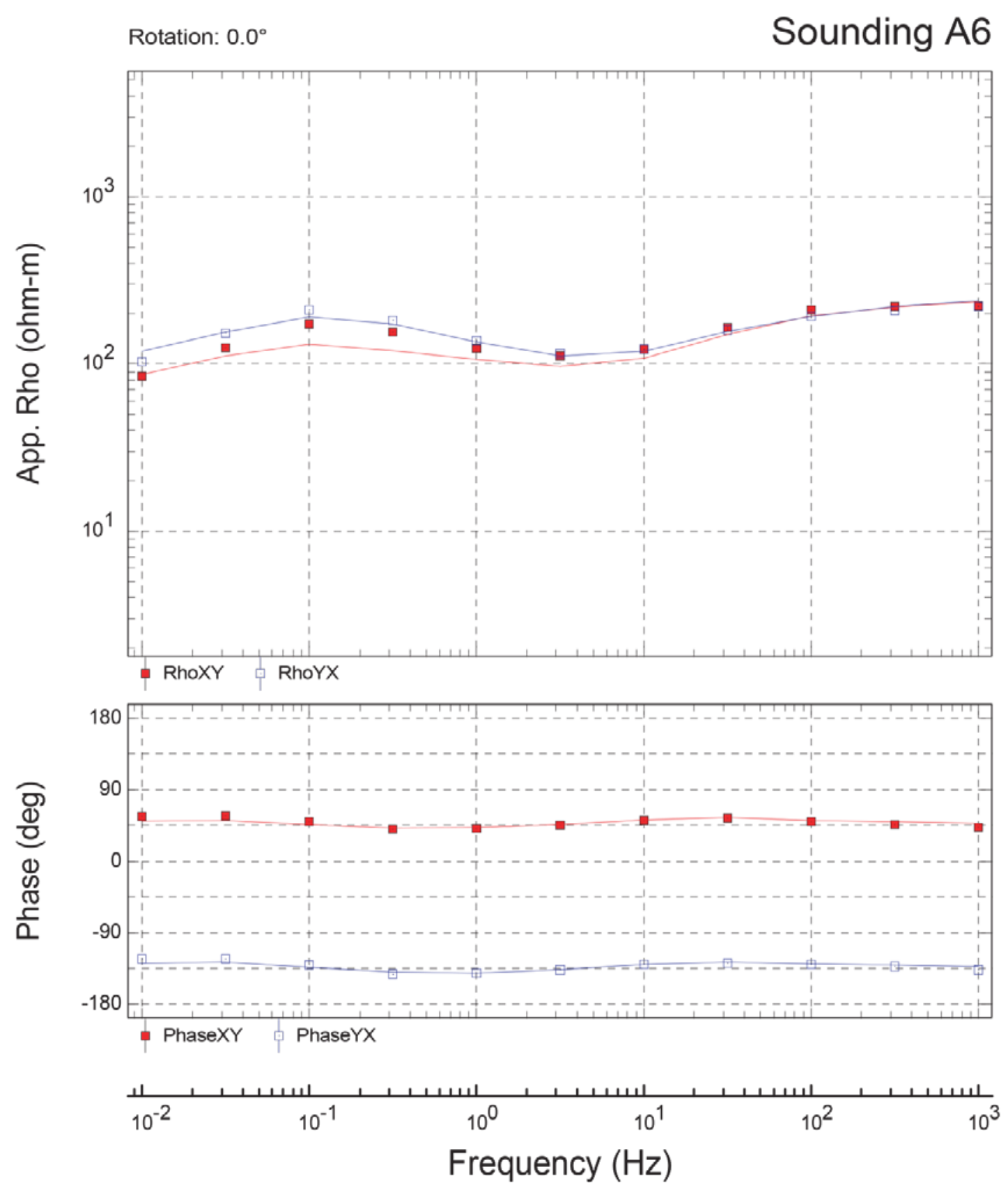



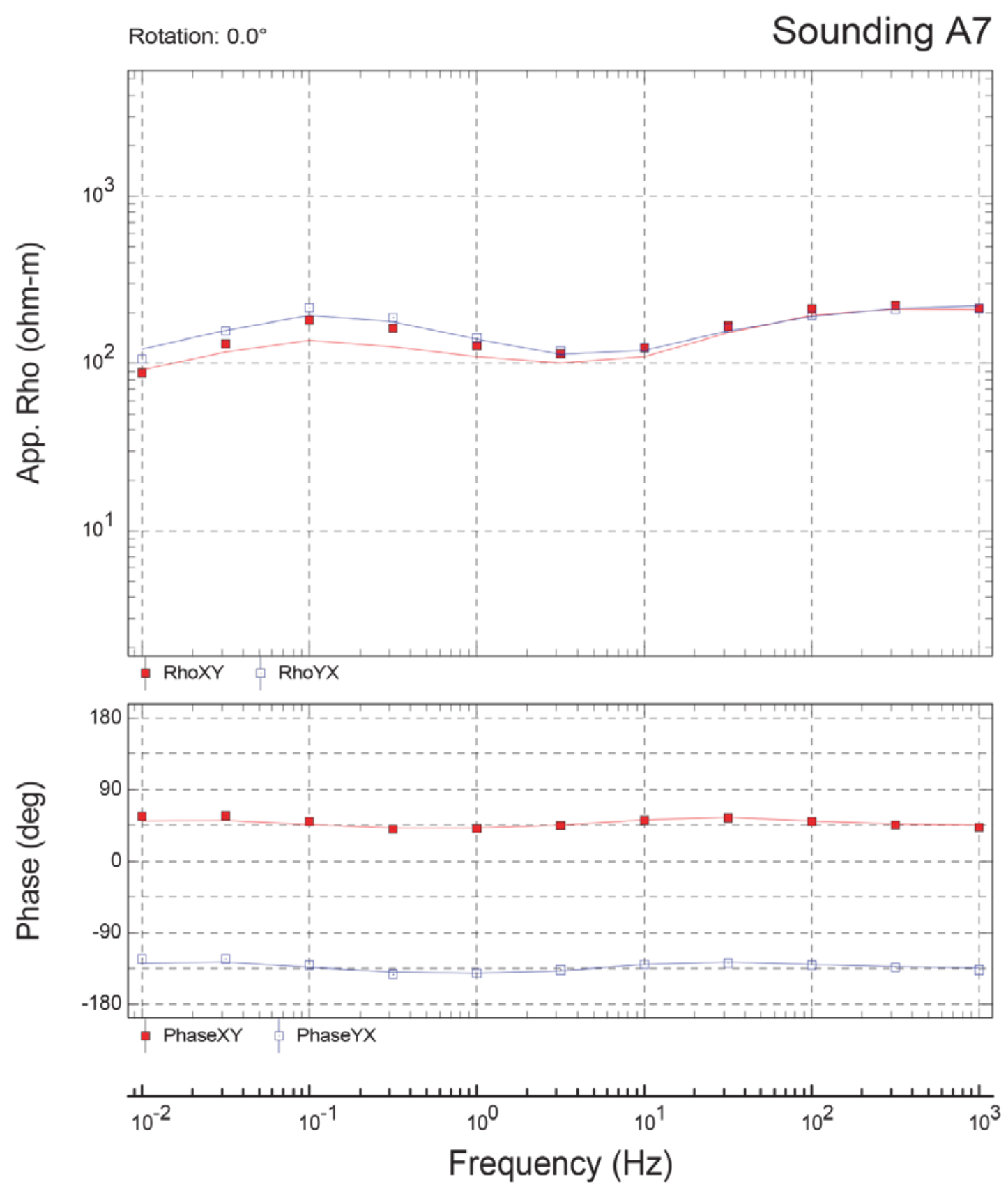


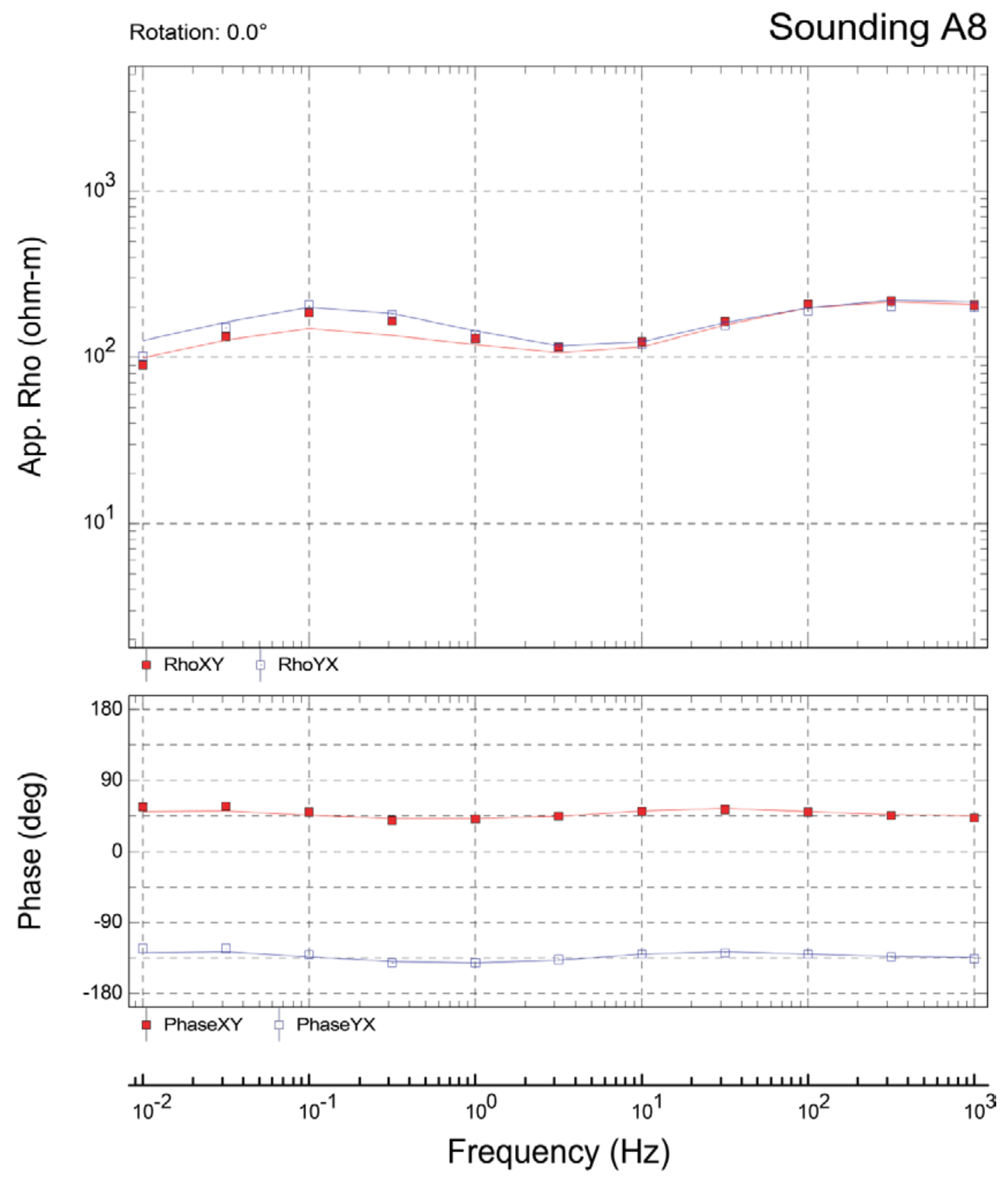




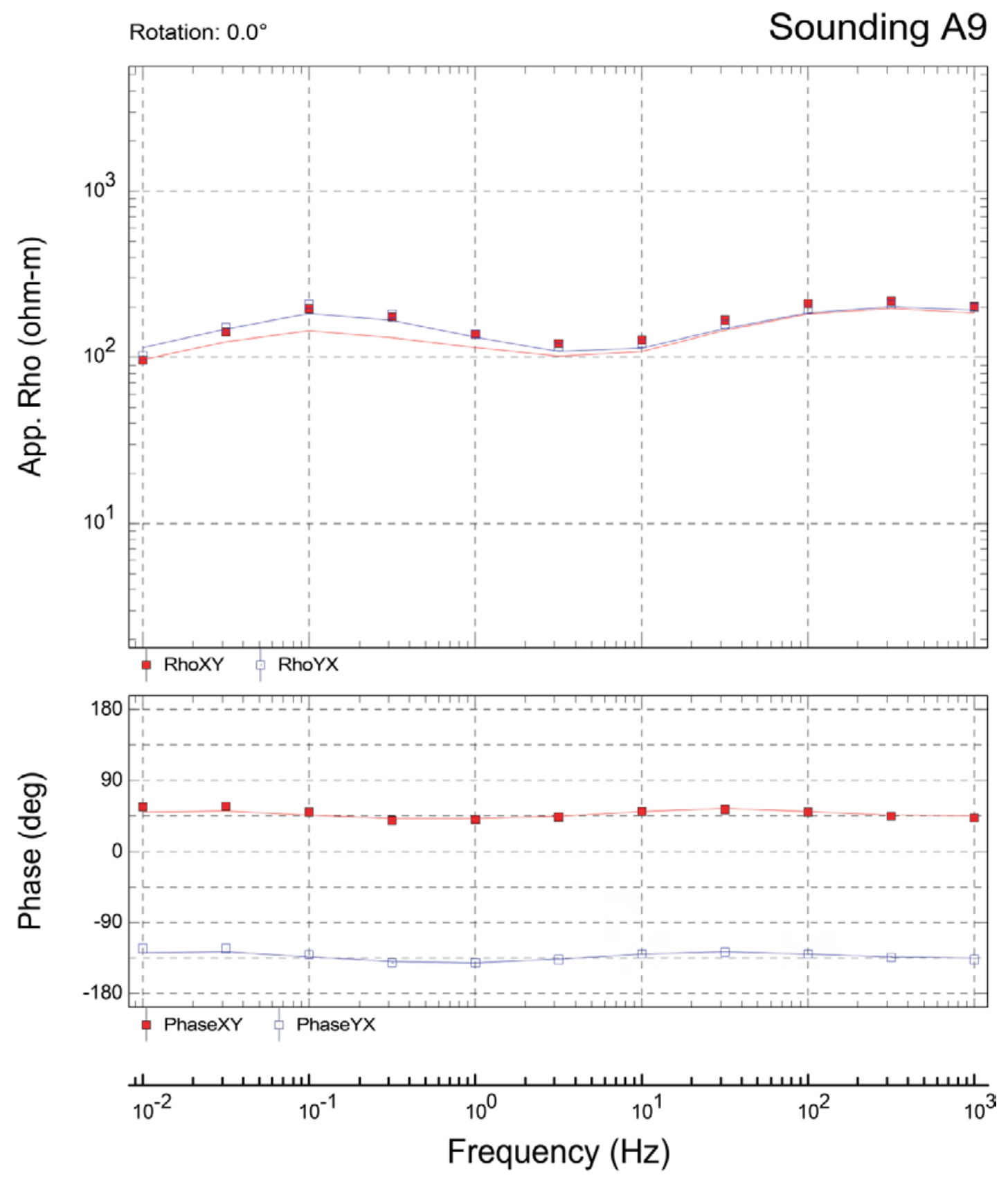




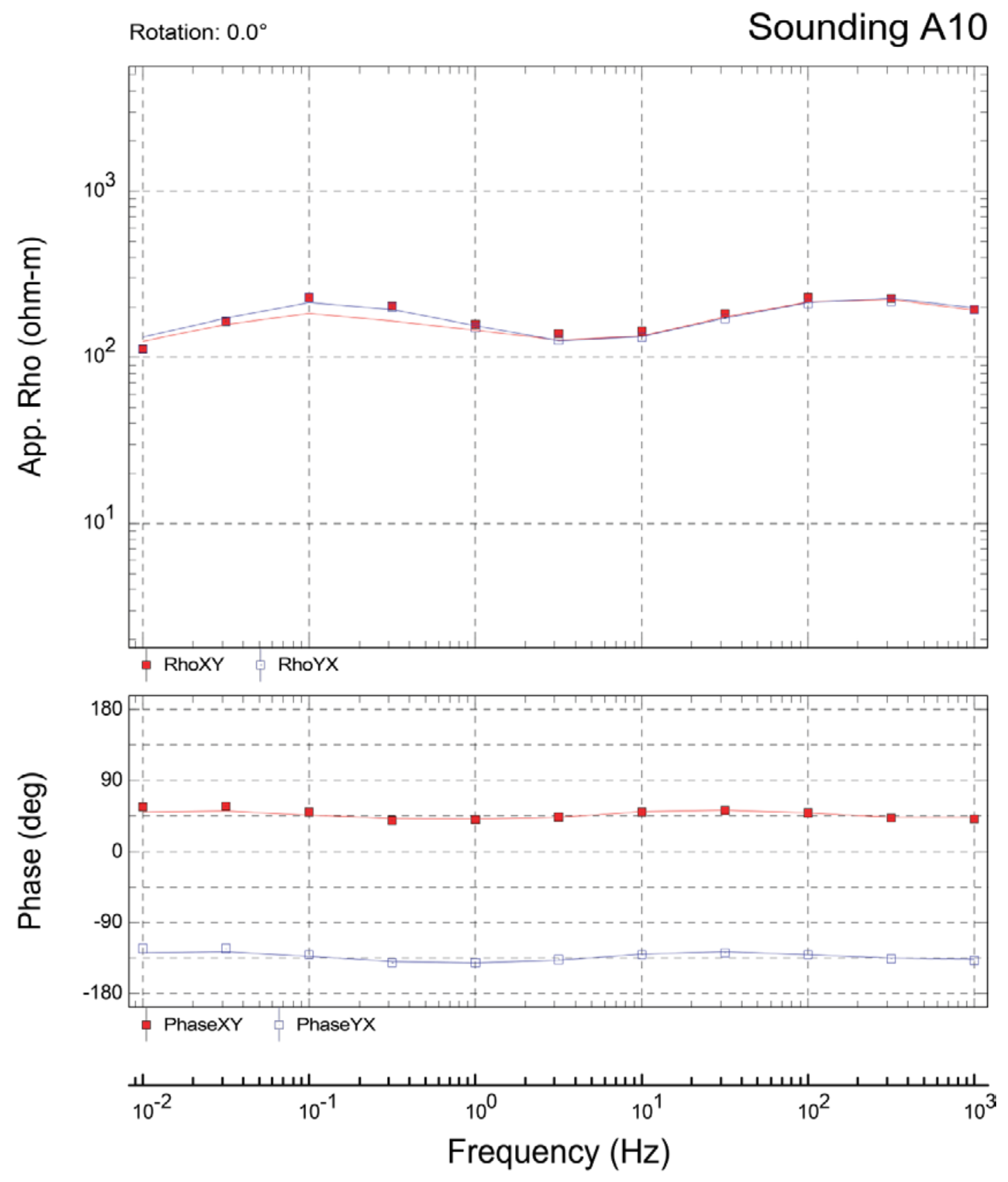



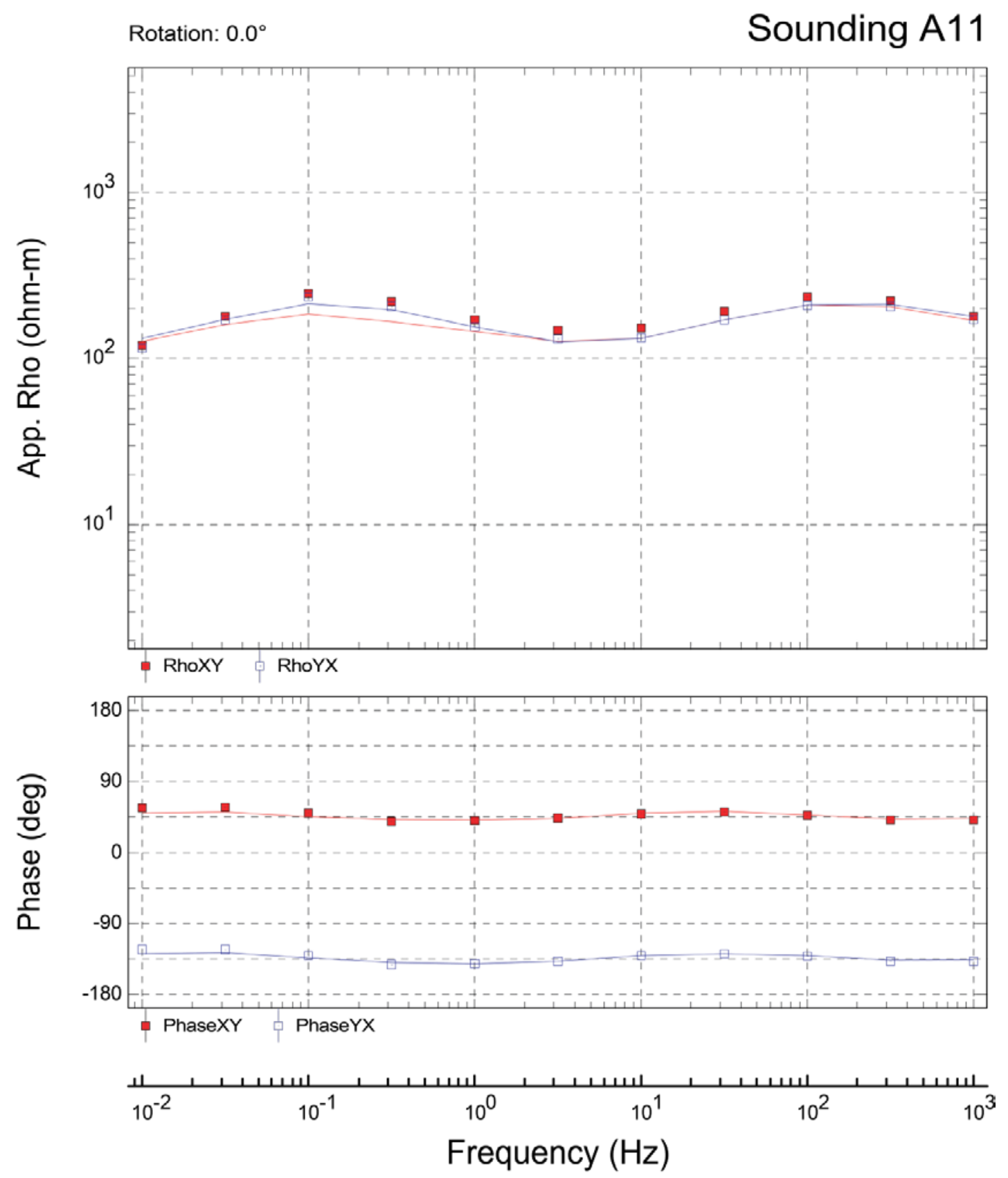

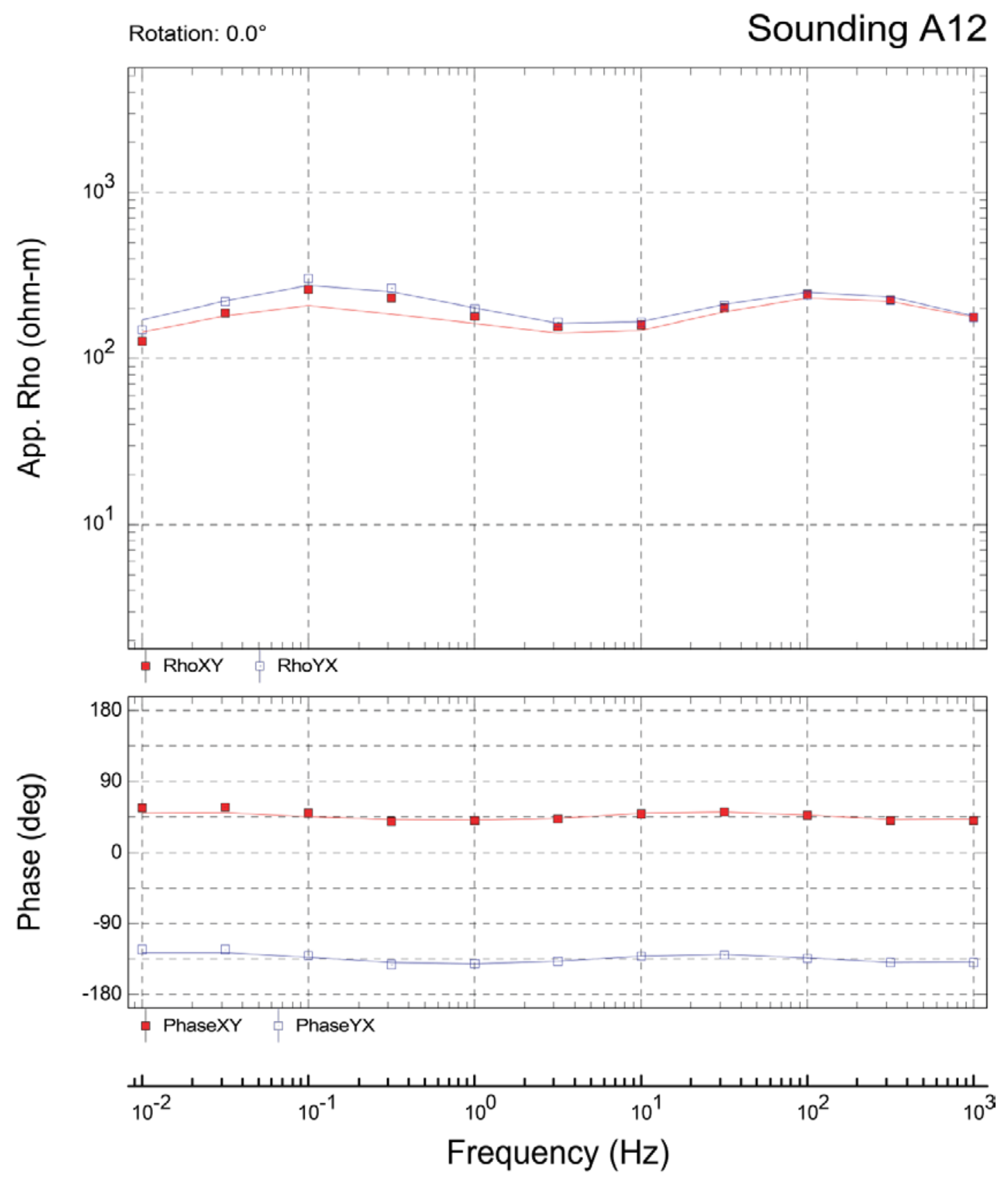


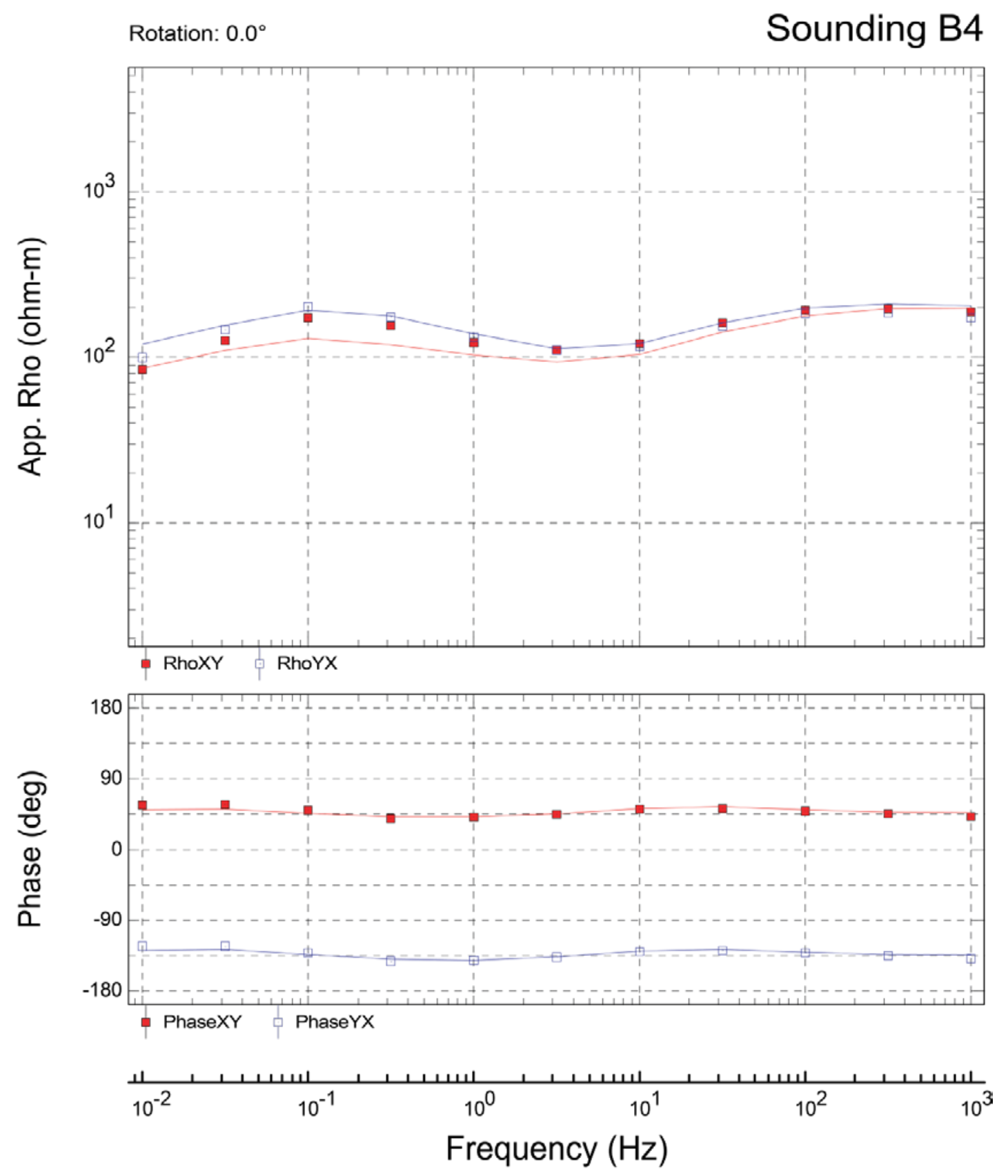

Figure 14. Soundings B4-B12. Pahute Mesa three-dimensional resistivity inversion data along profile B. All other labels, symbols, and lines are as in figure 13. 


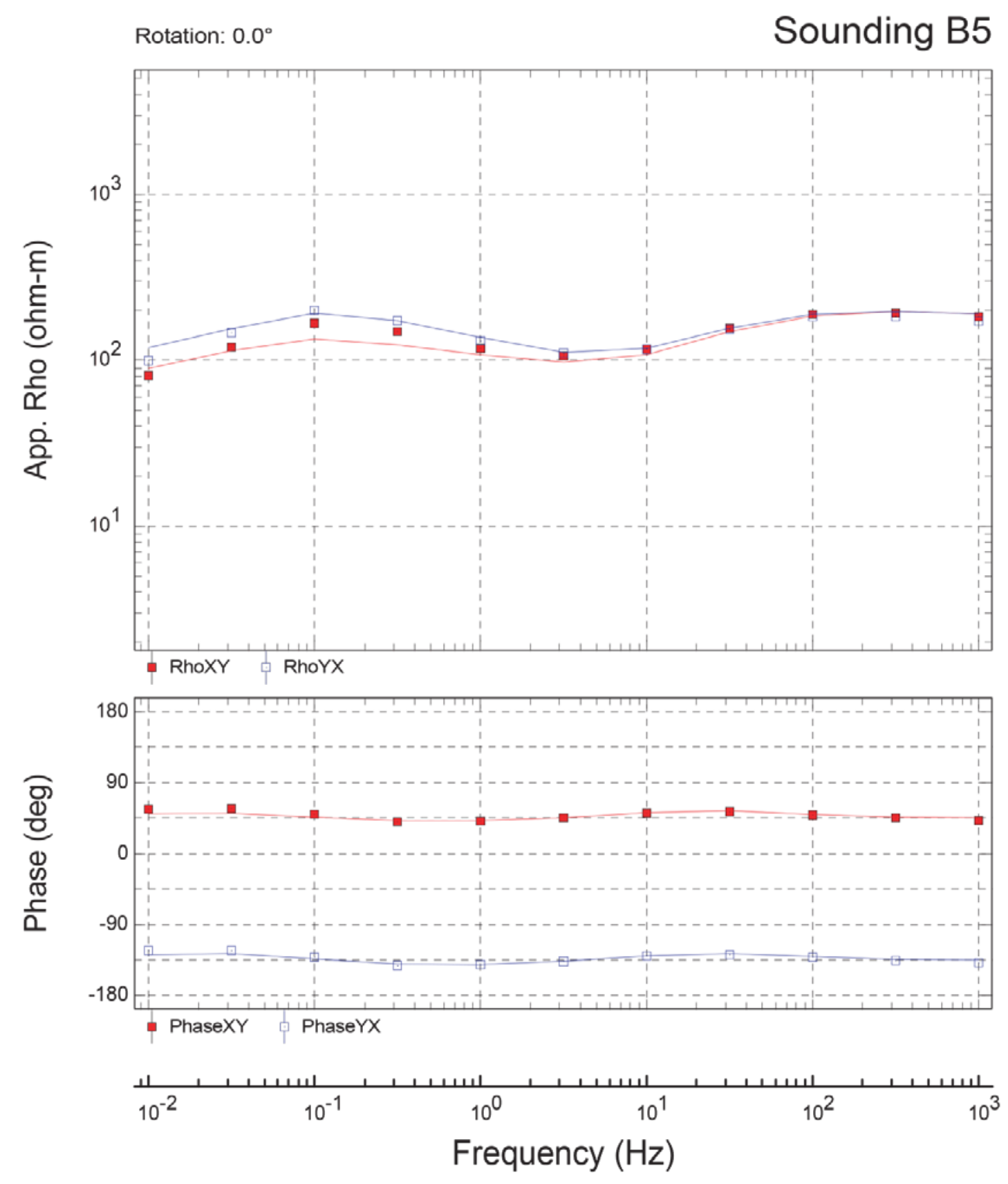




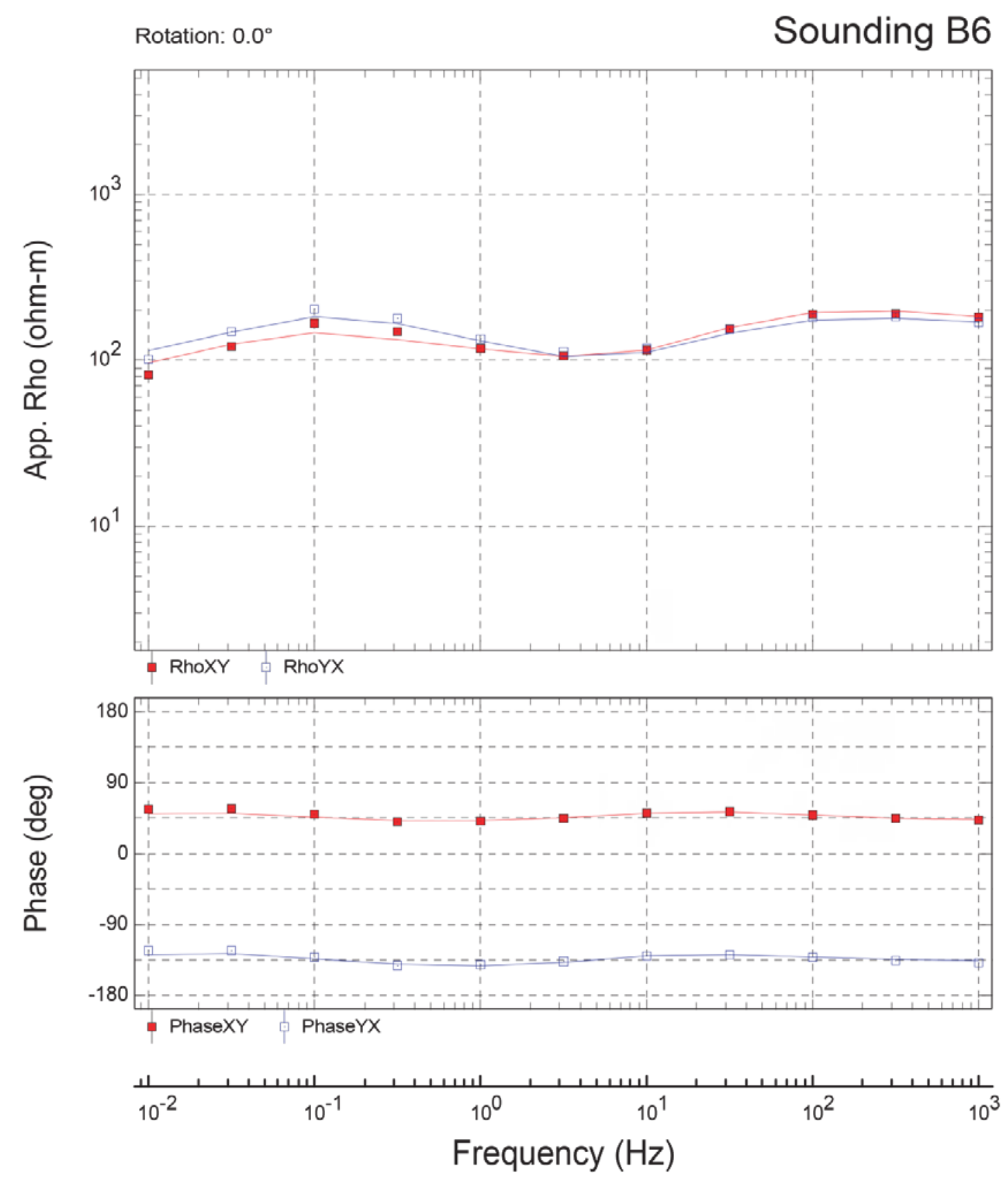



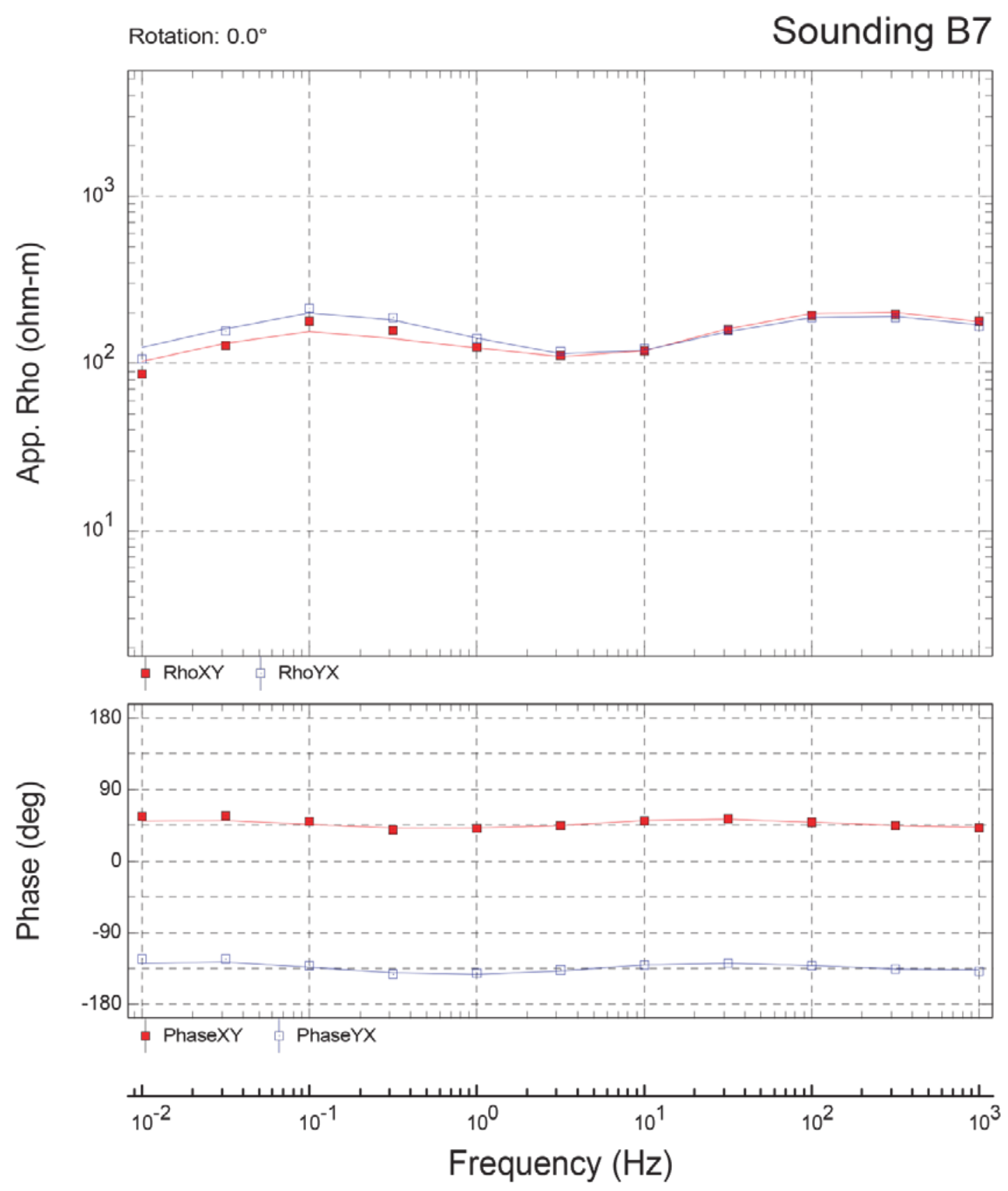


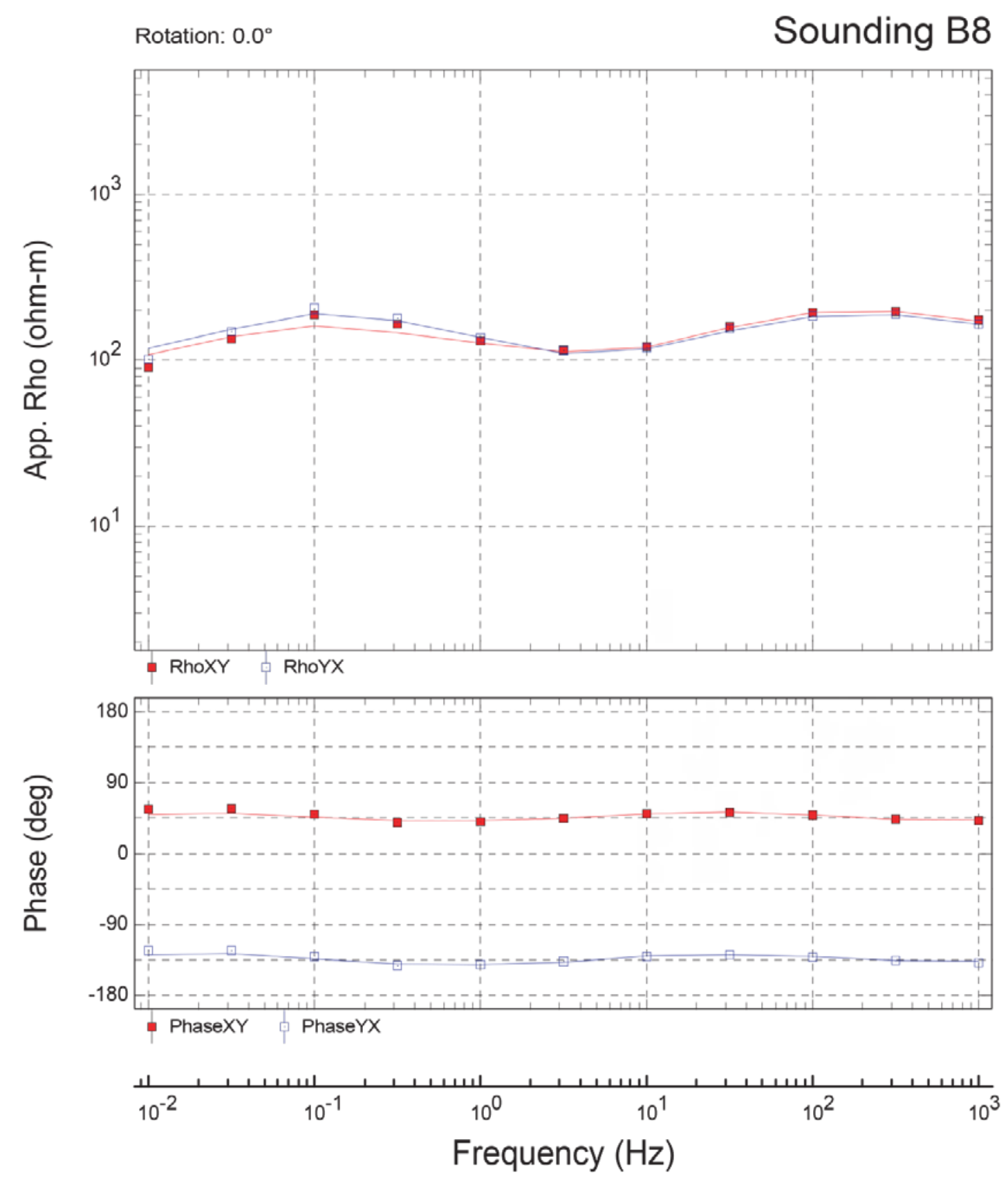




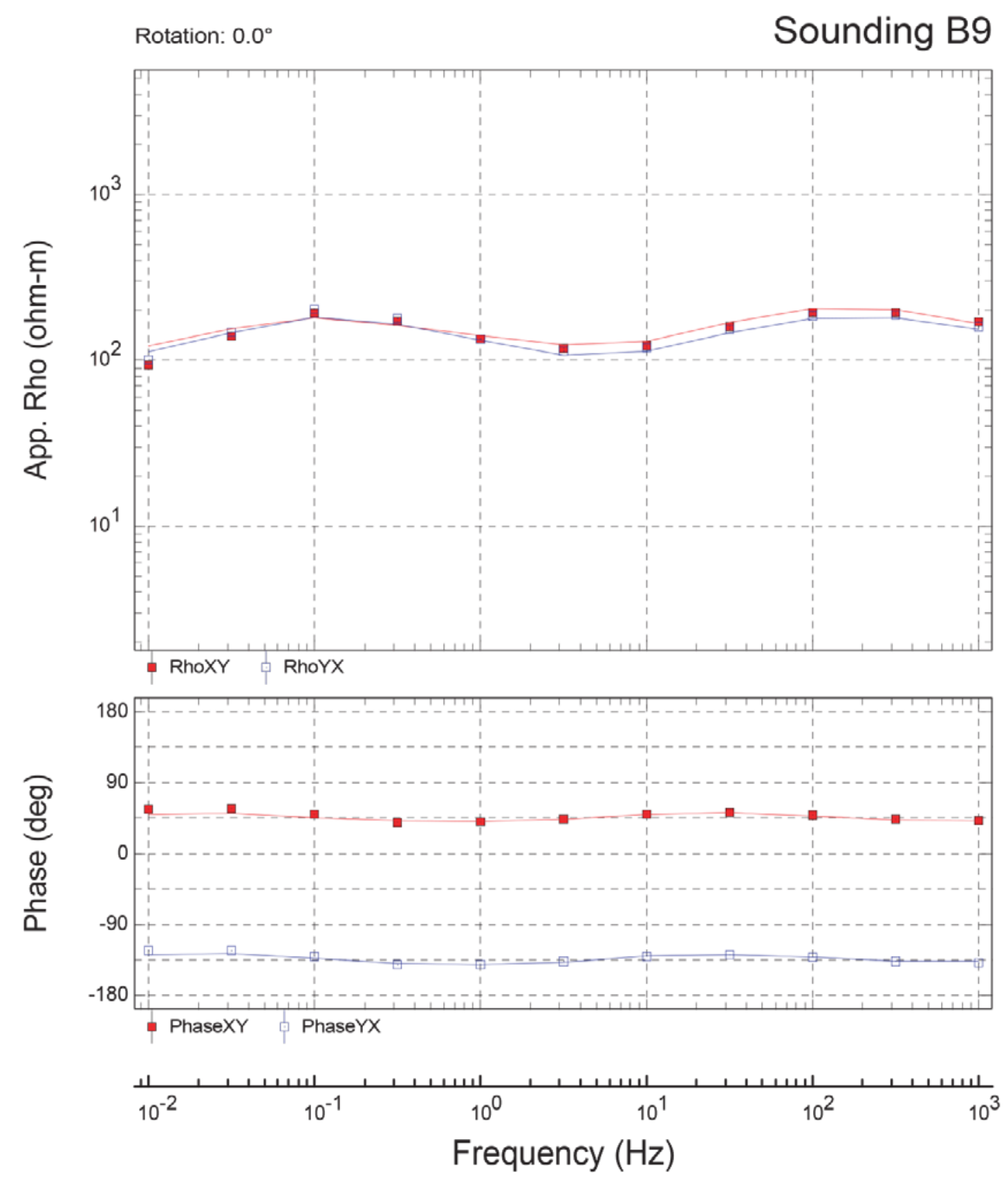




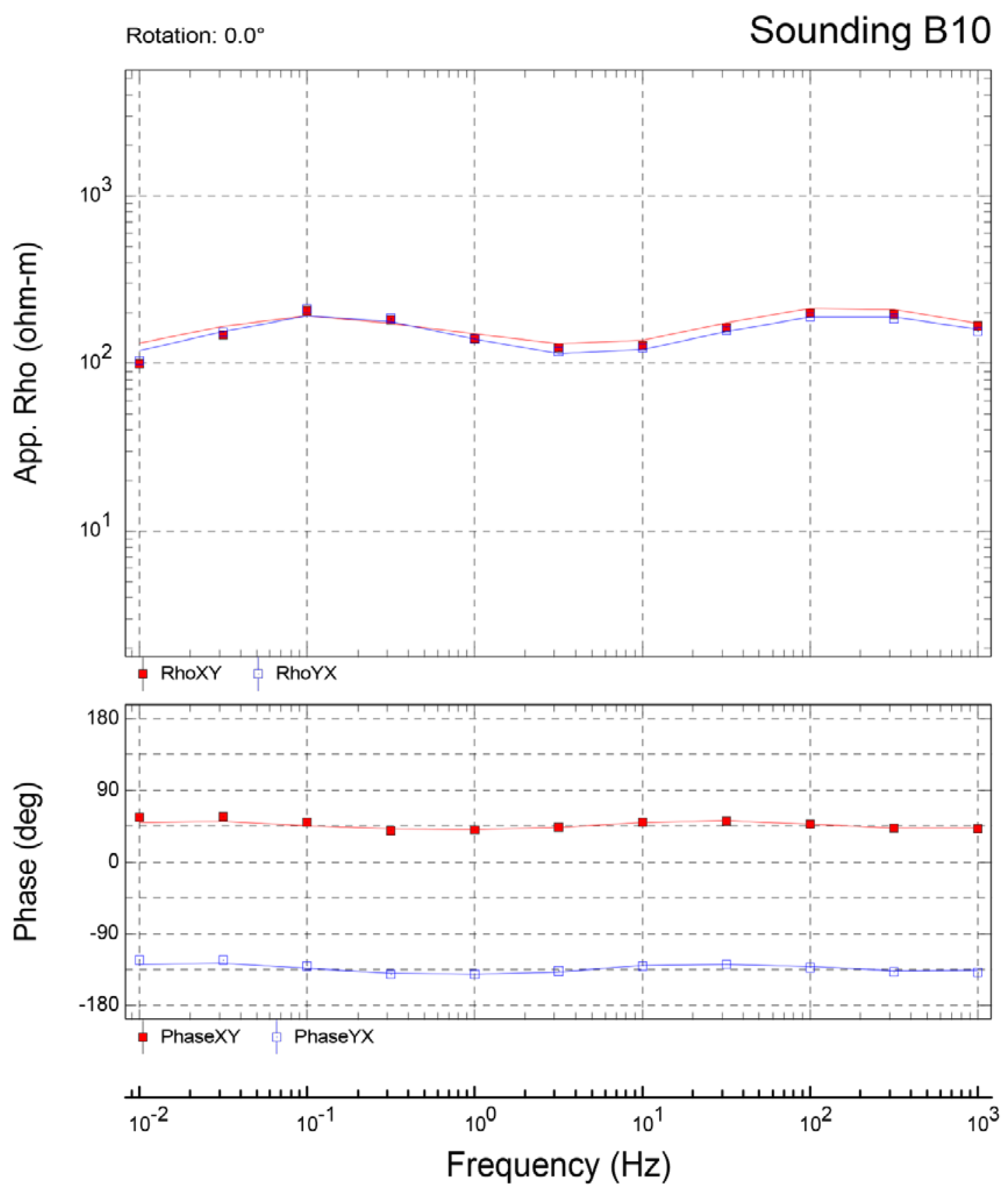




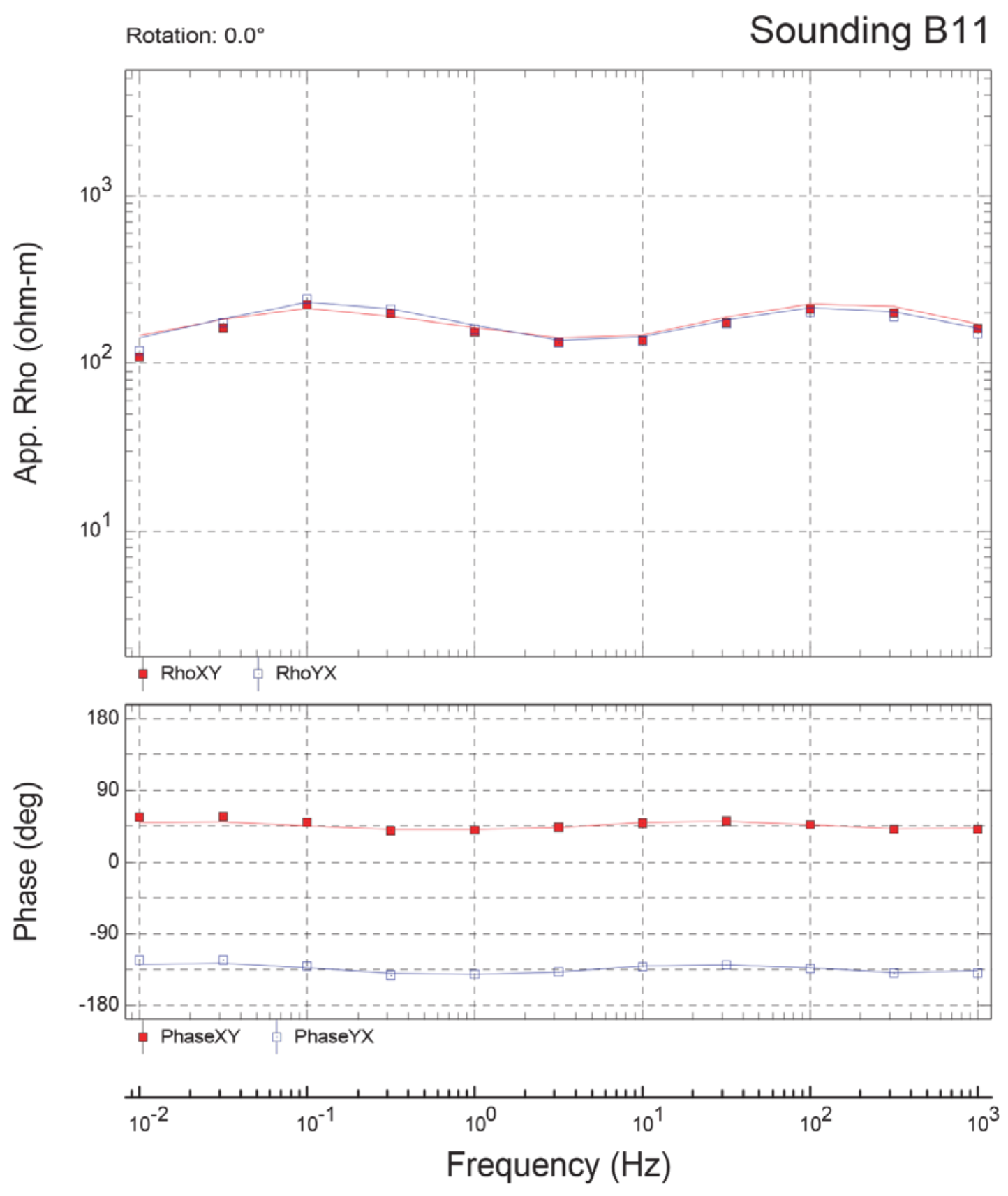




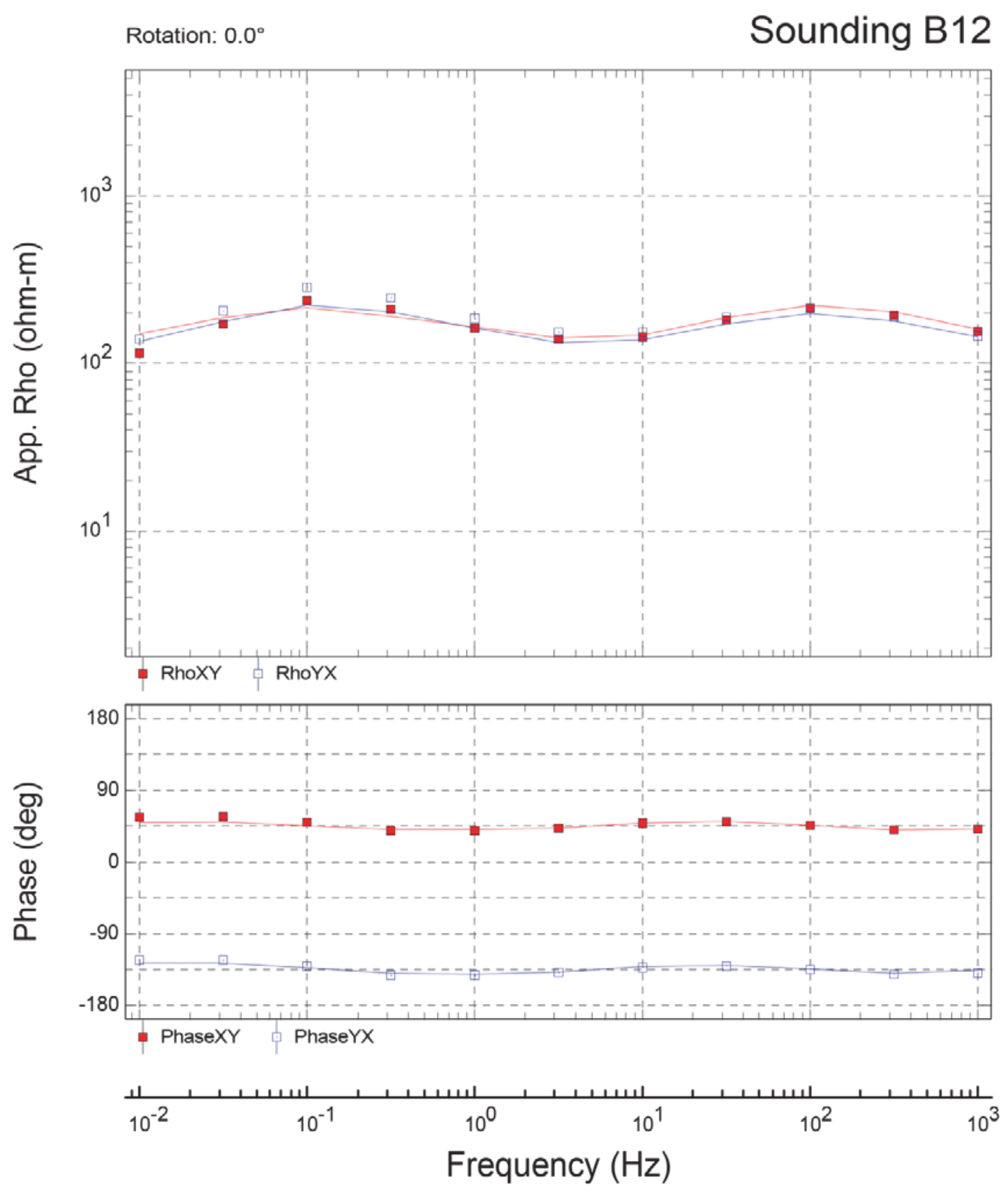



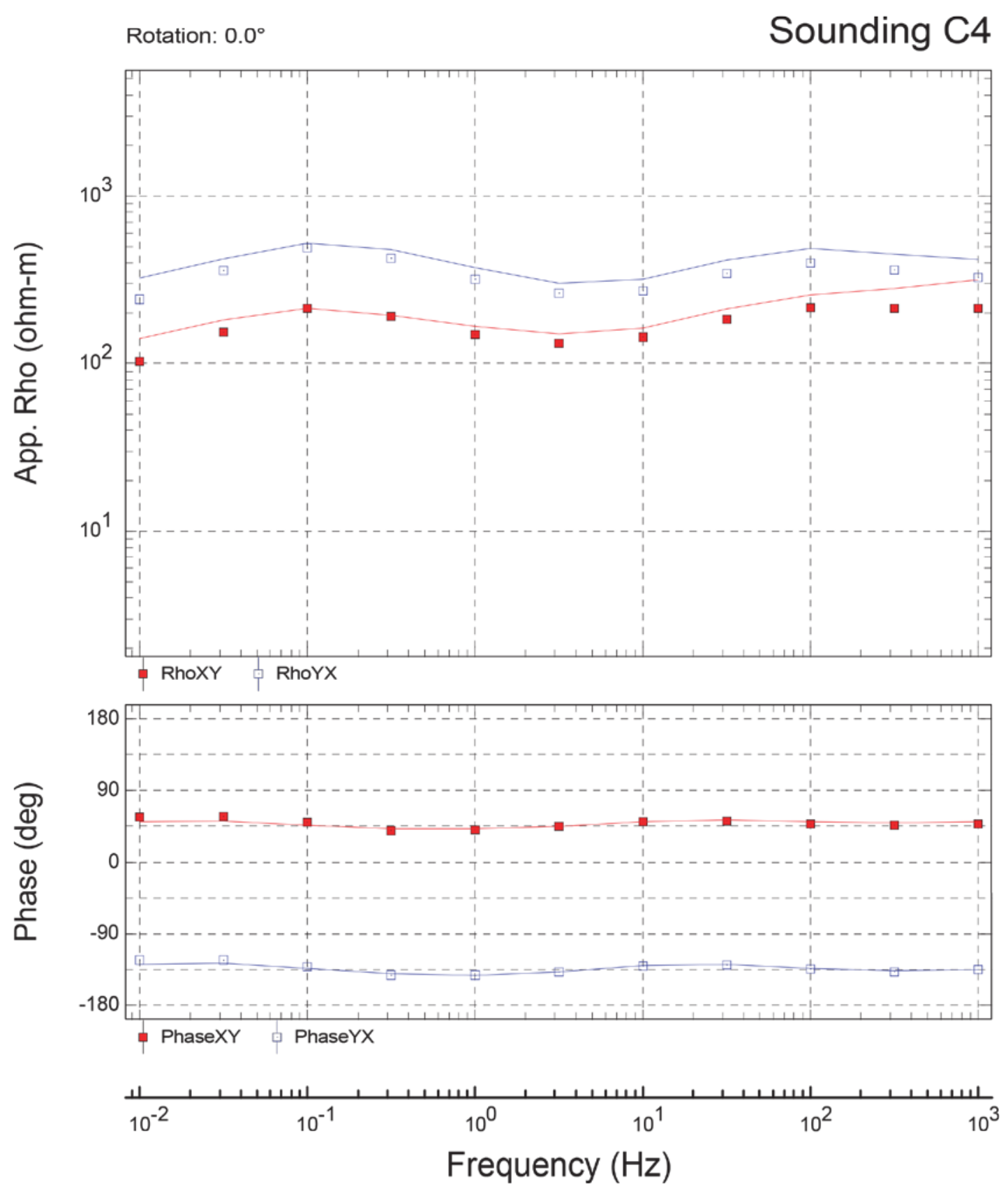

Figure 15. Soundings $\mathrm{C} 4-\mathrm{C} 12$. Pahute Mesa three-dimensional resistivity inversion data along profile $\mathrm{C}$. All other labels, symbols, and lines are as in figure 13. 

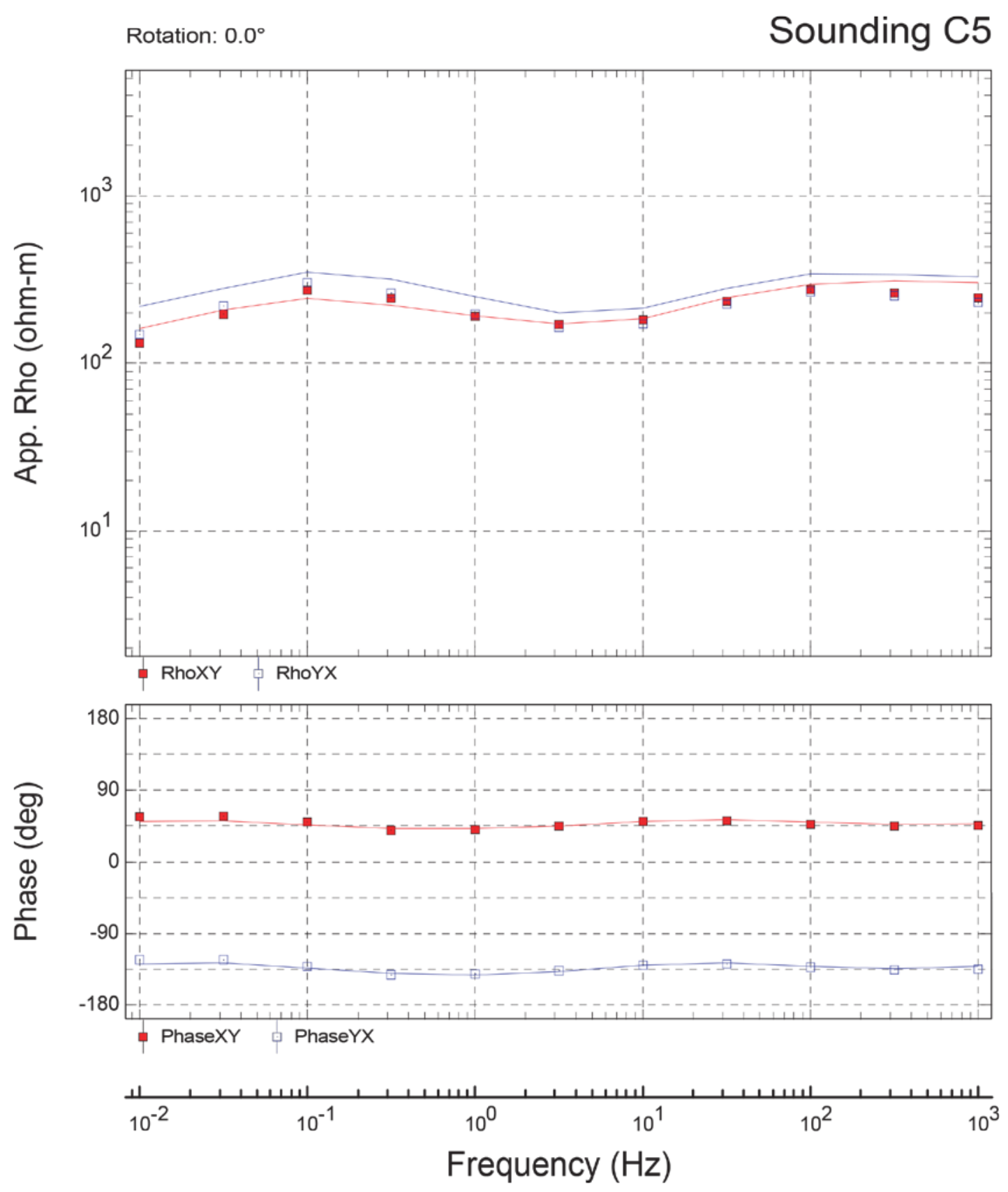


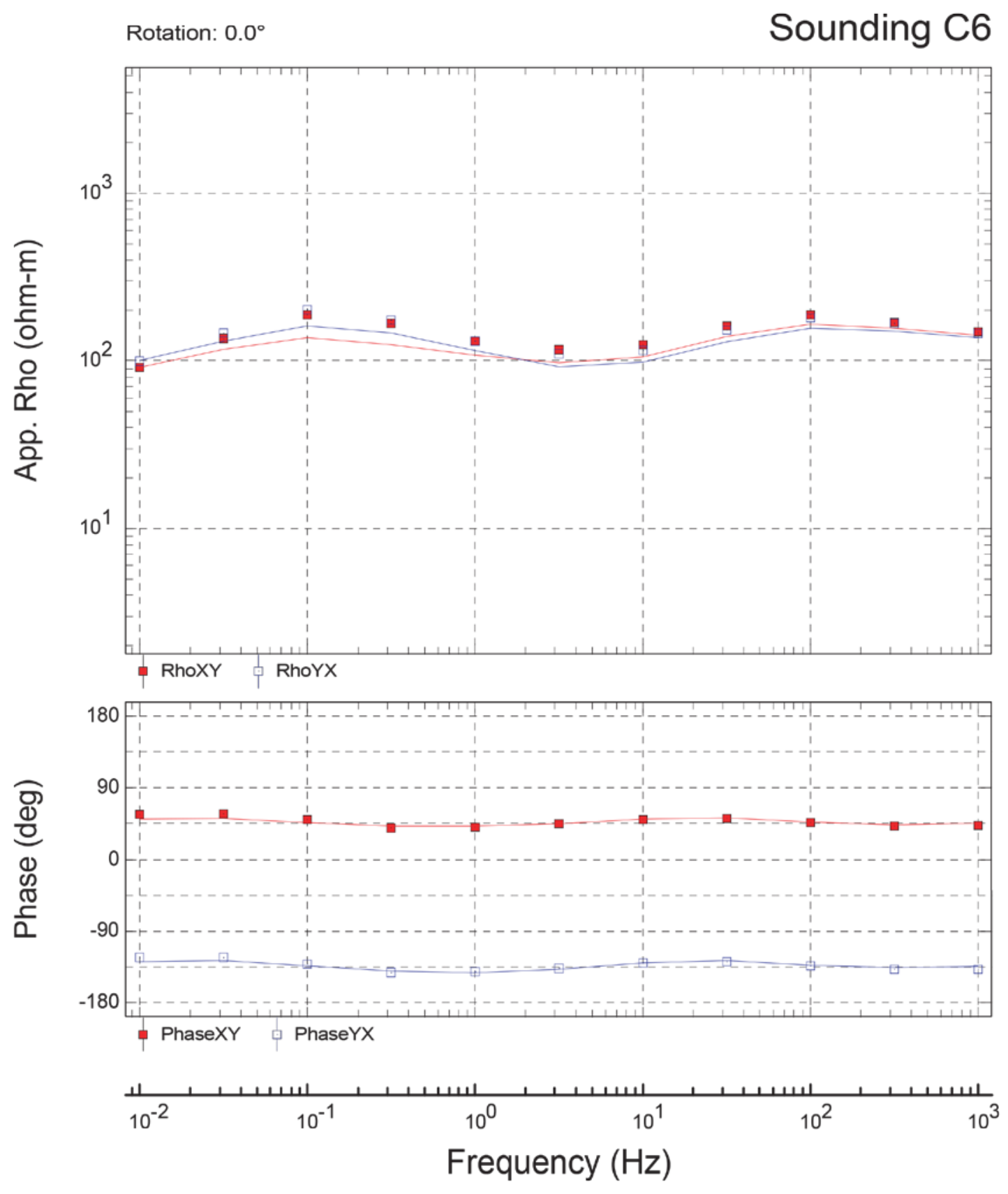



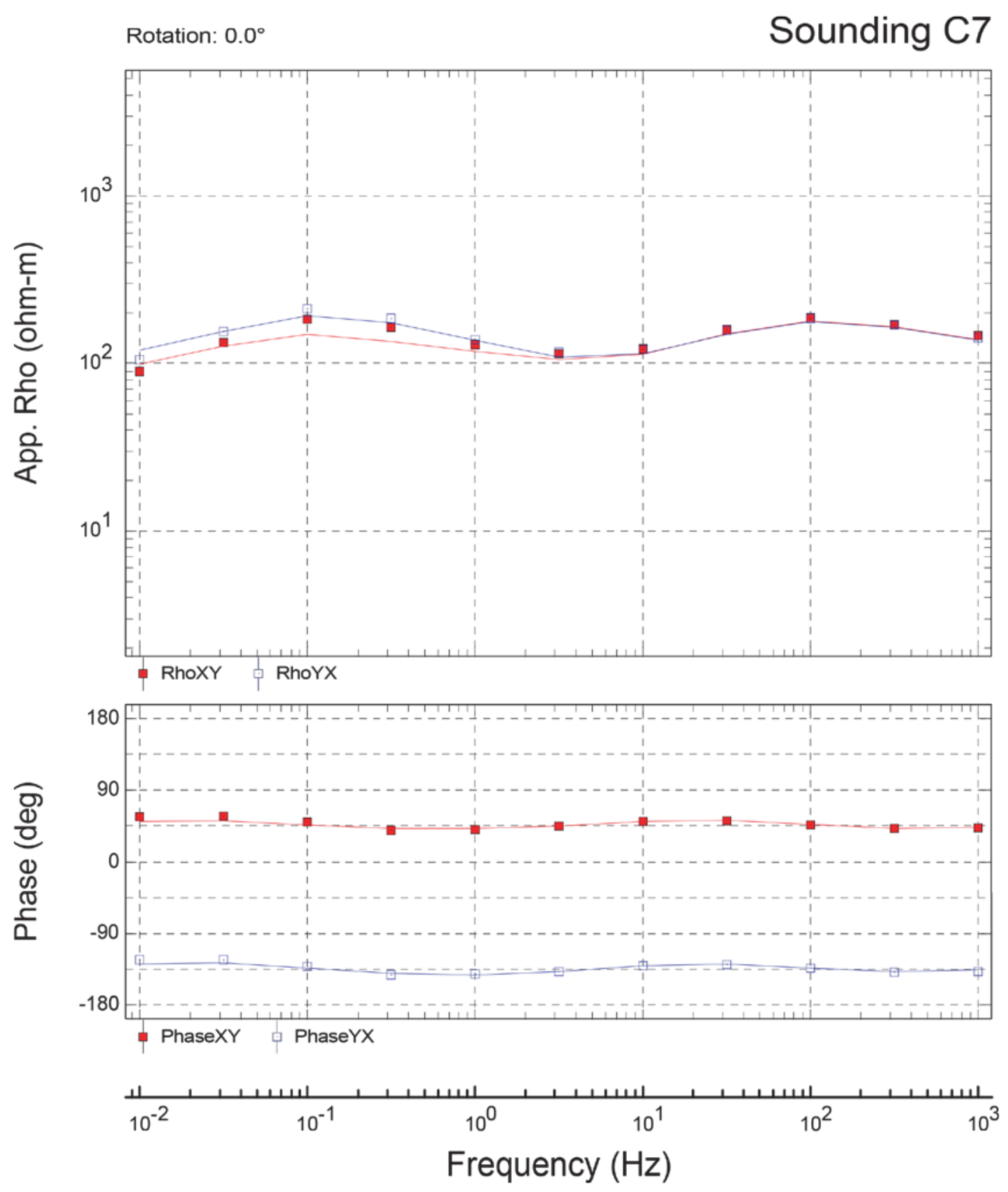


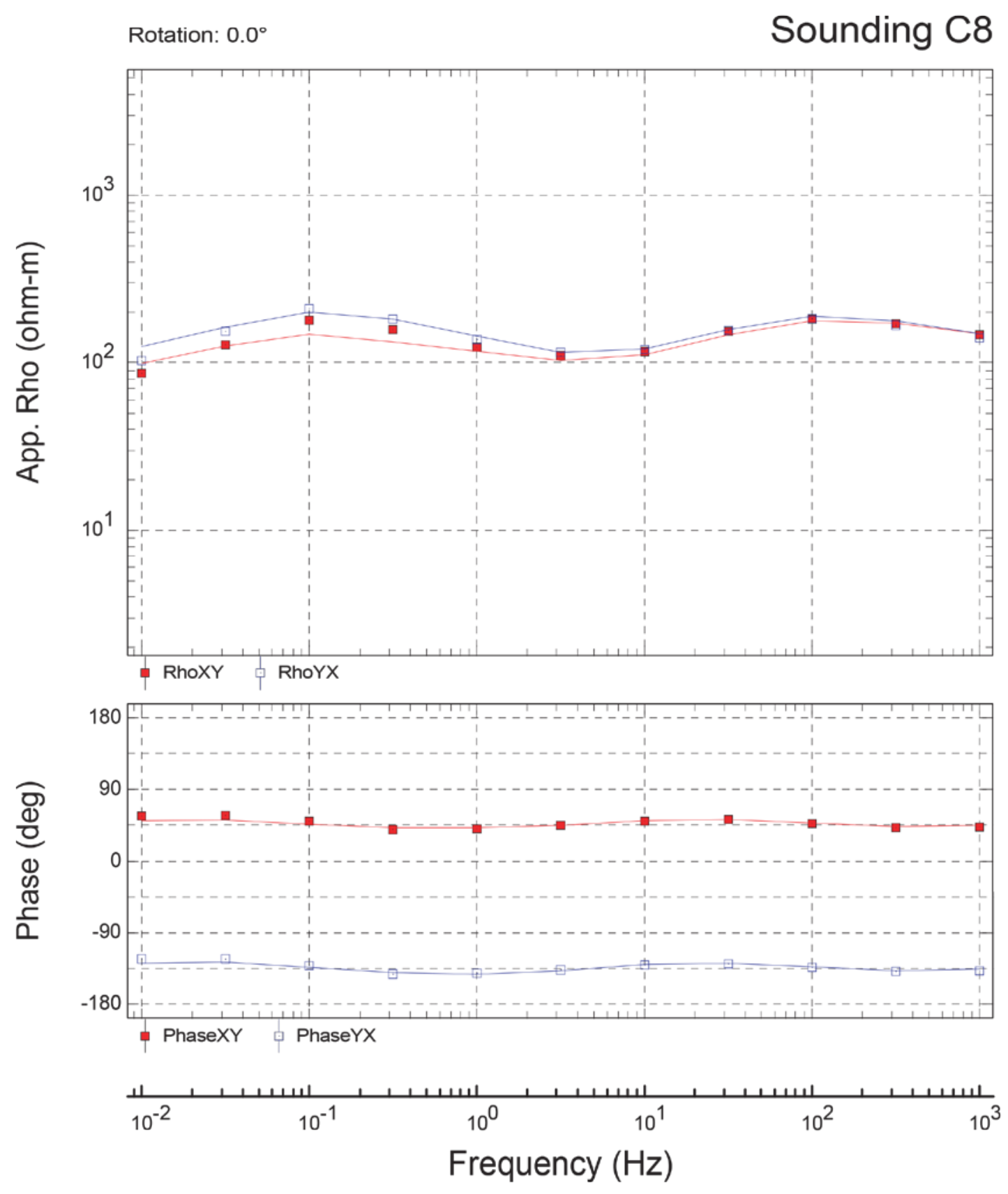



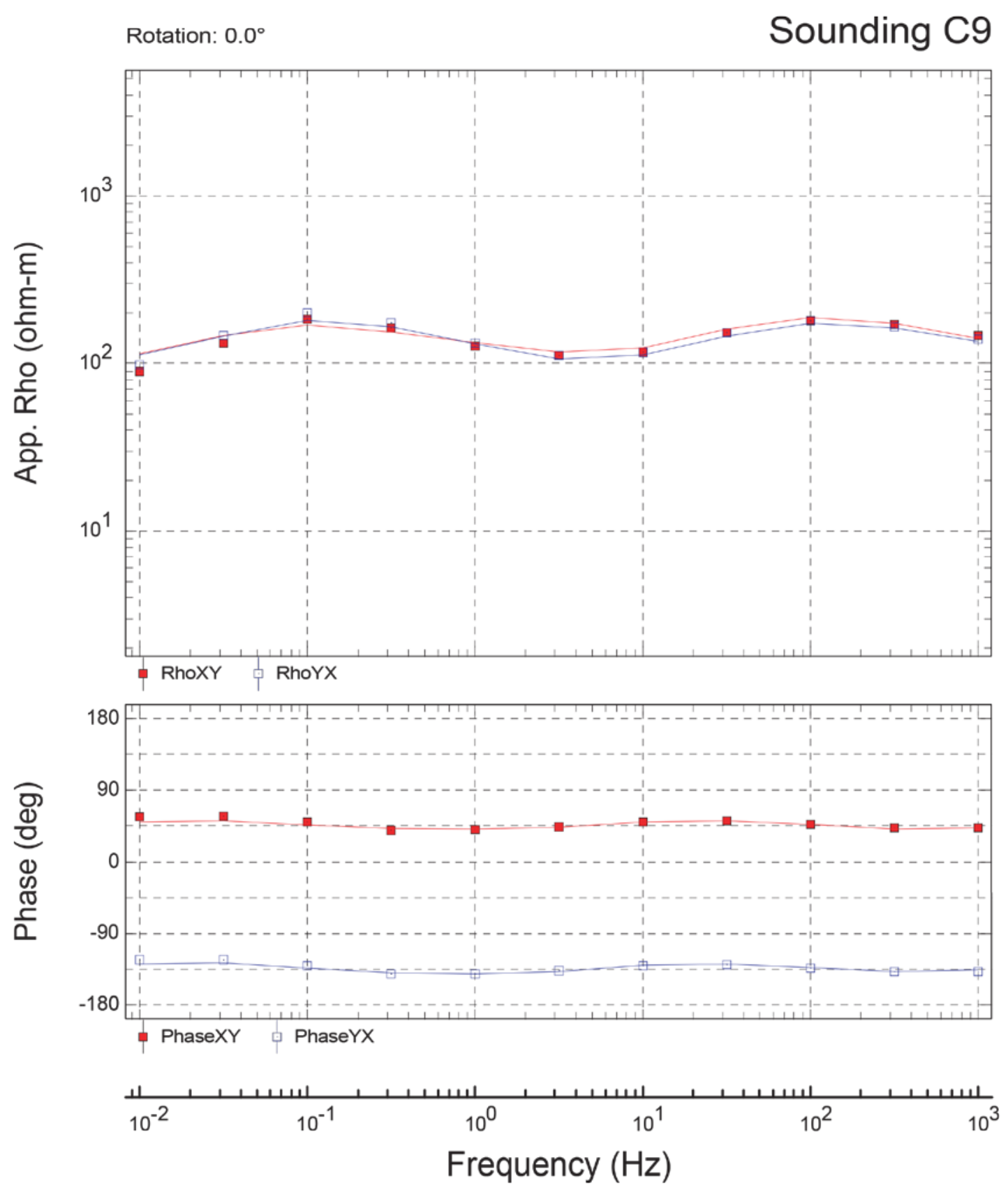

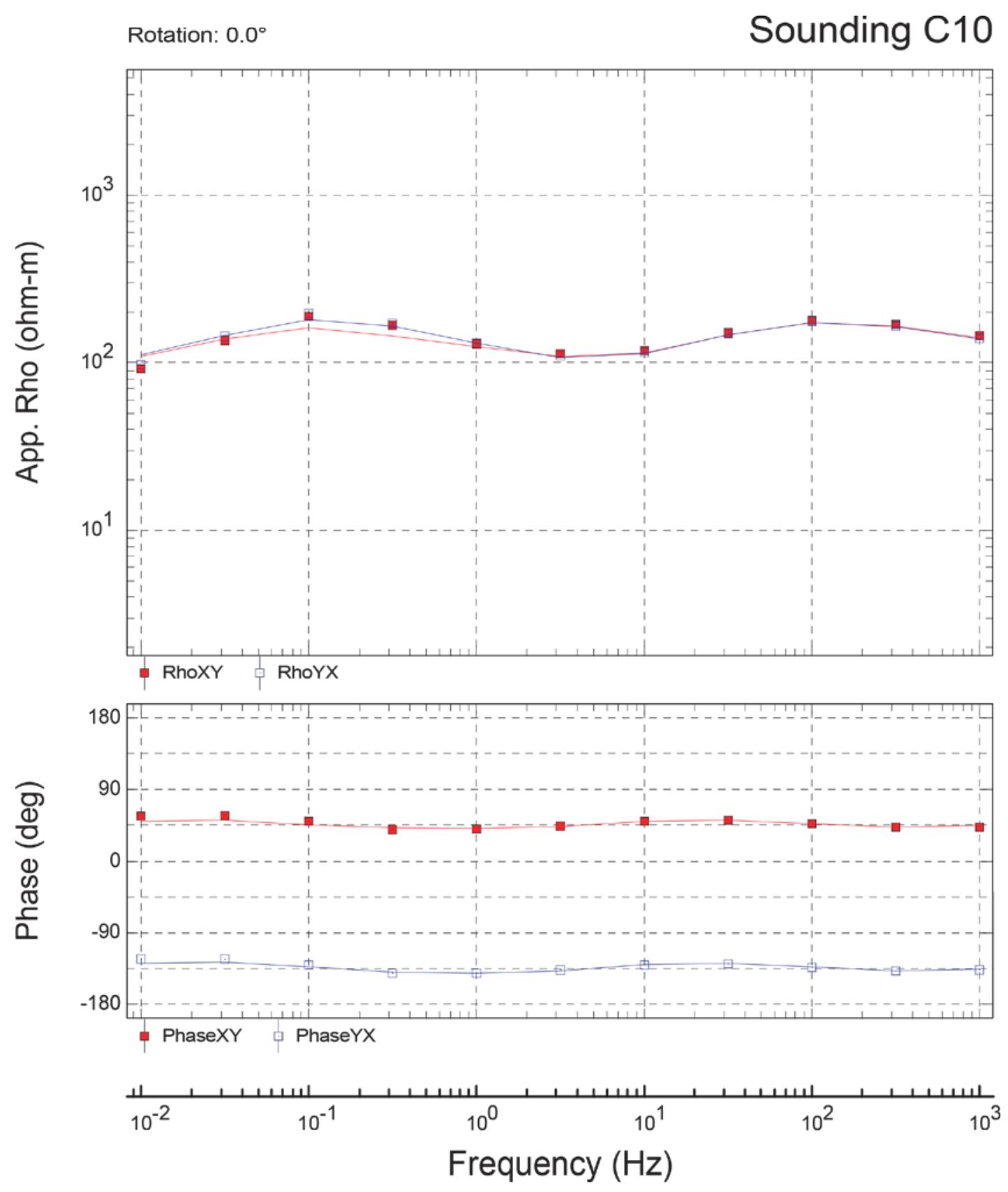

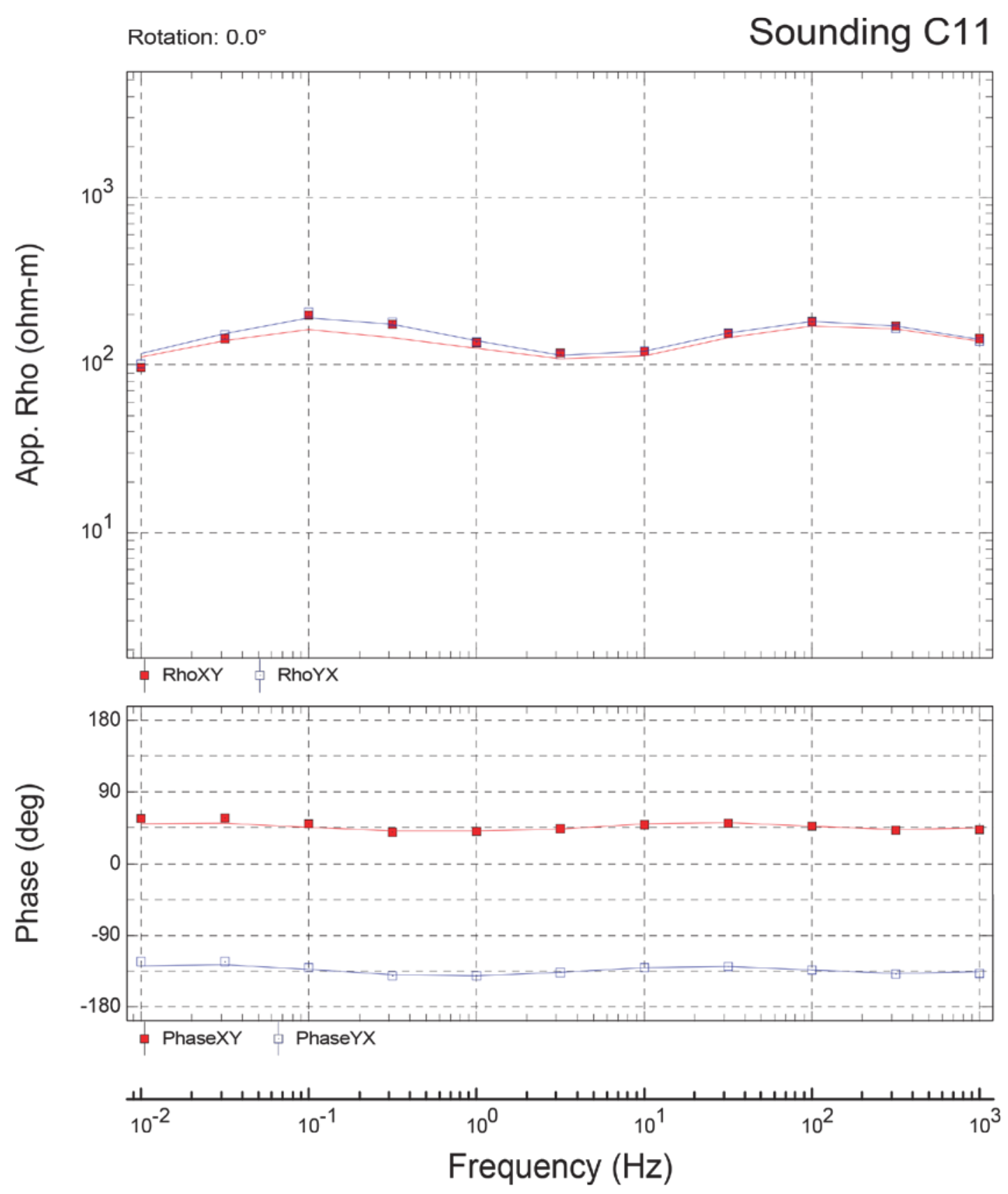

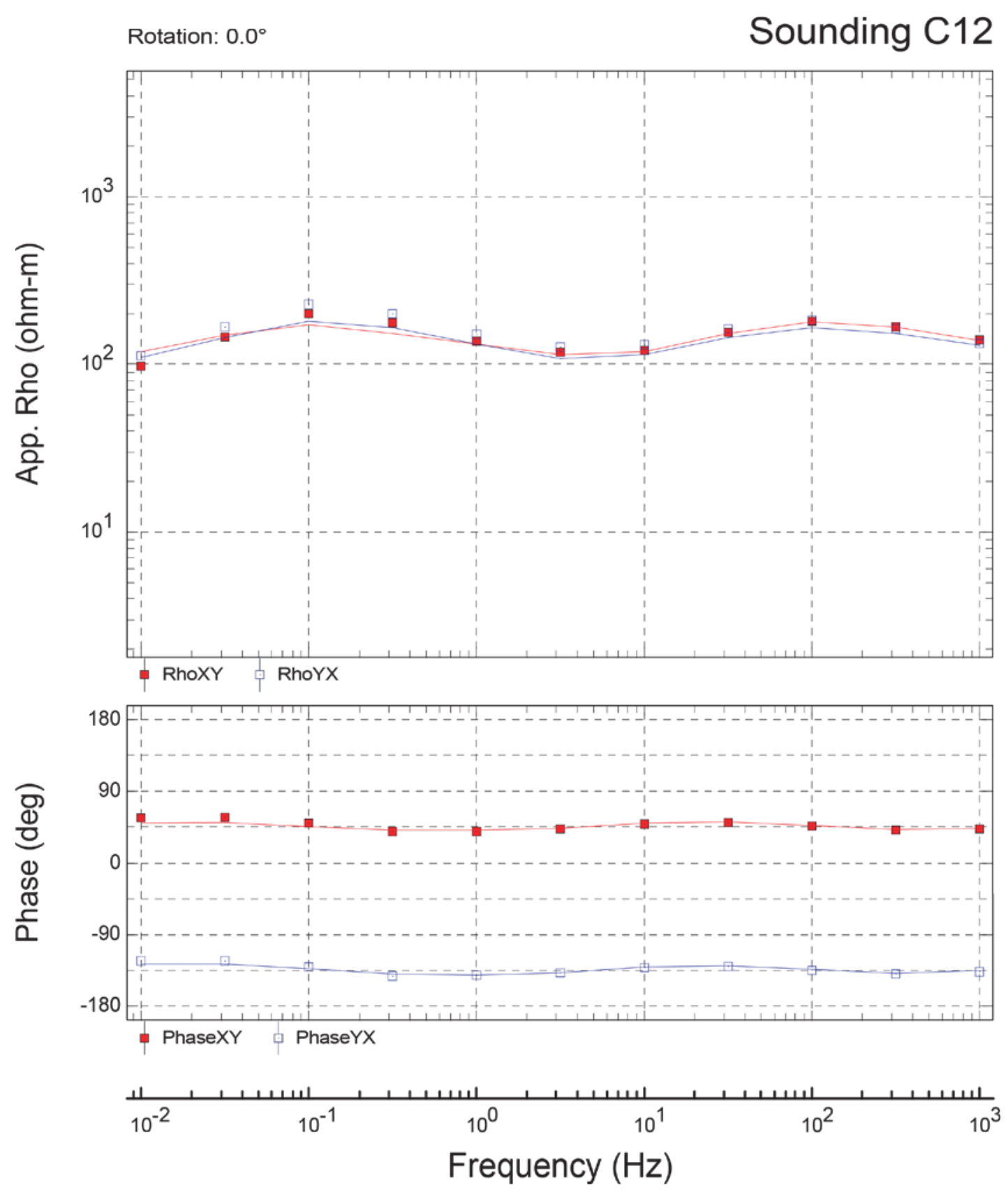

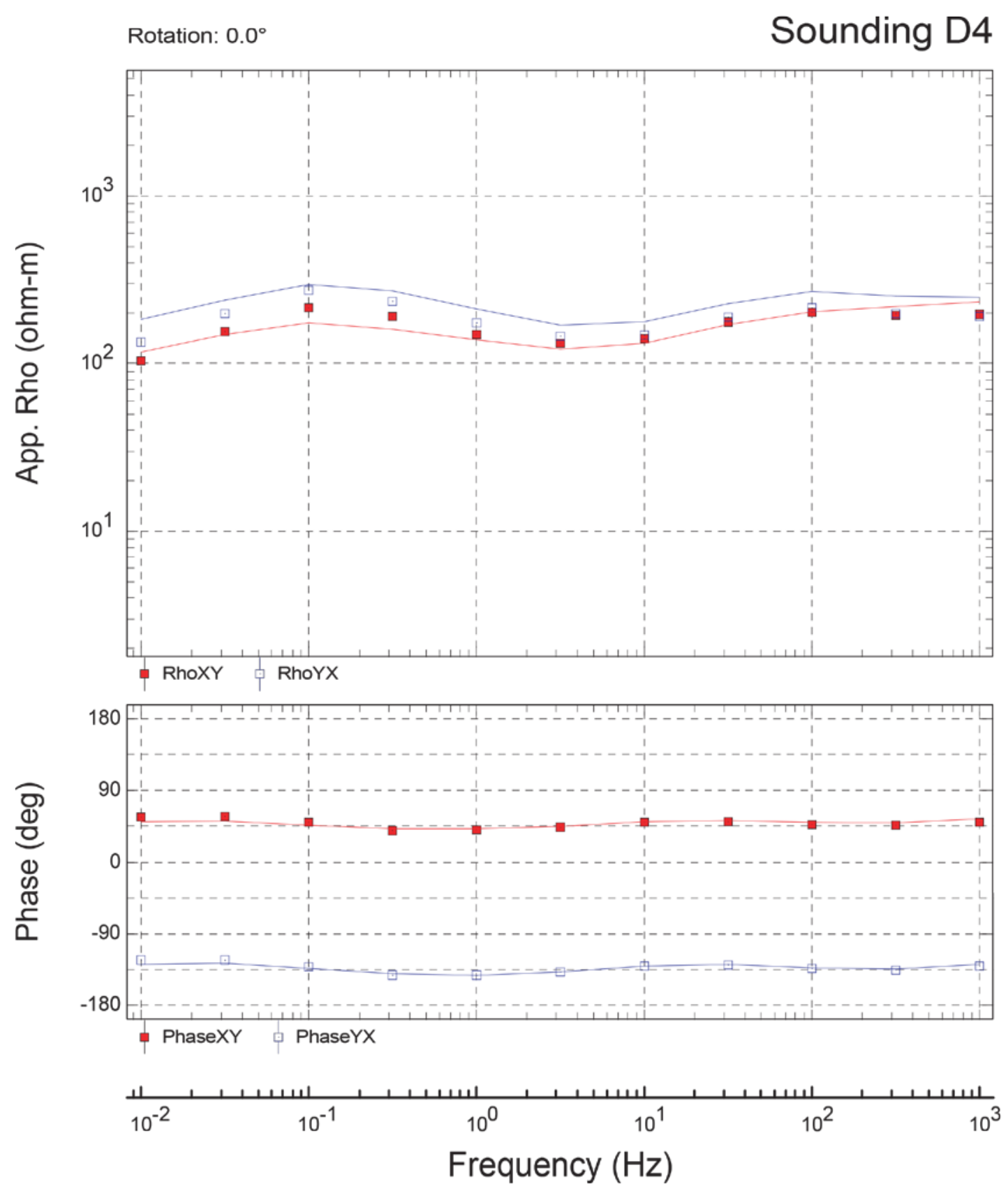

Figure 16. Soundings D4-D12. Pahute Mesa three-dimensional resistivity inversion data along profile D. All other labels, symbols, and lines are as in figure 13 

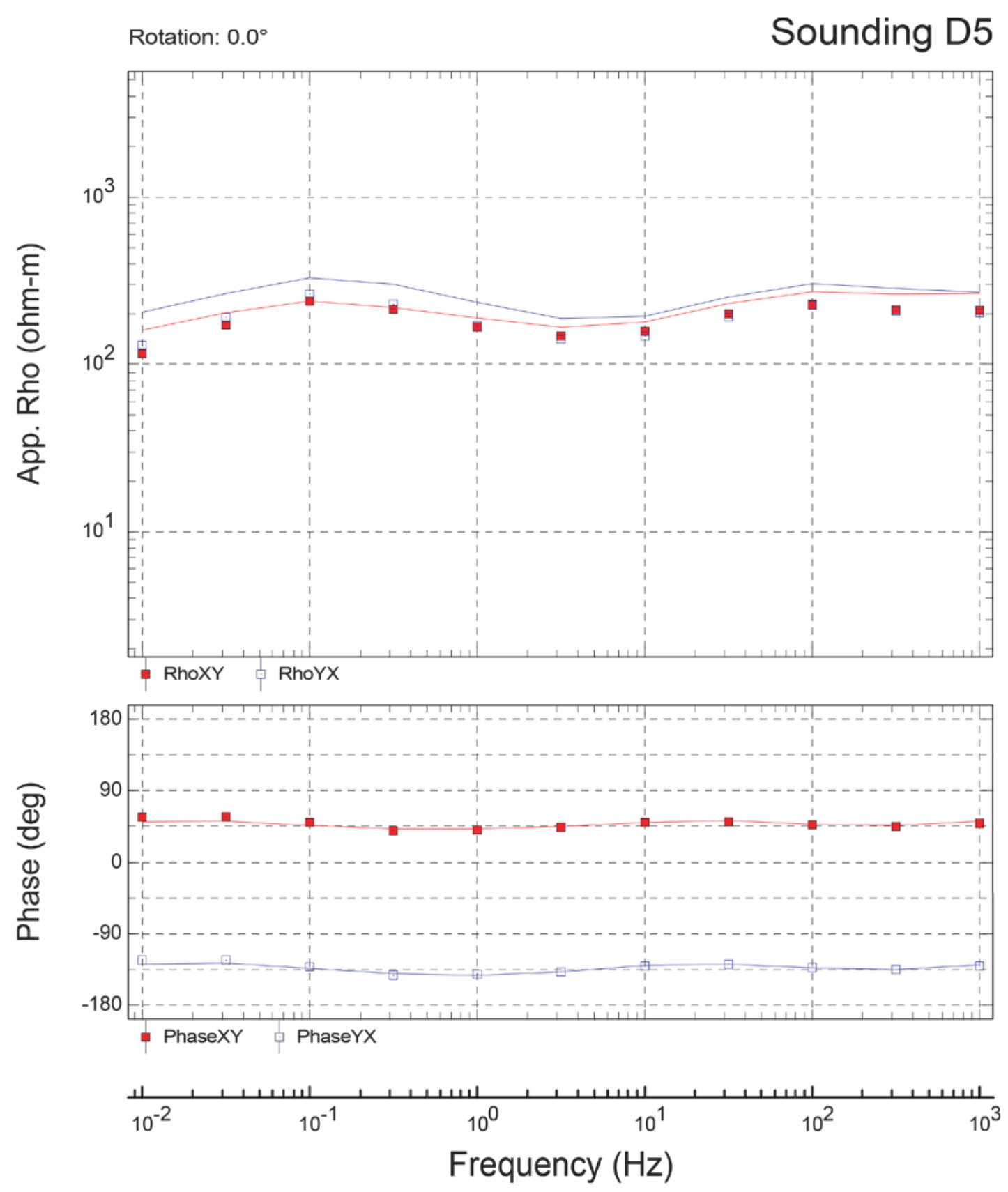

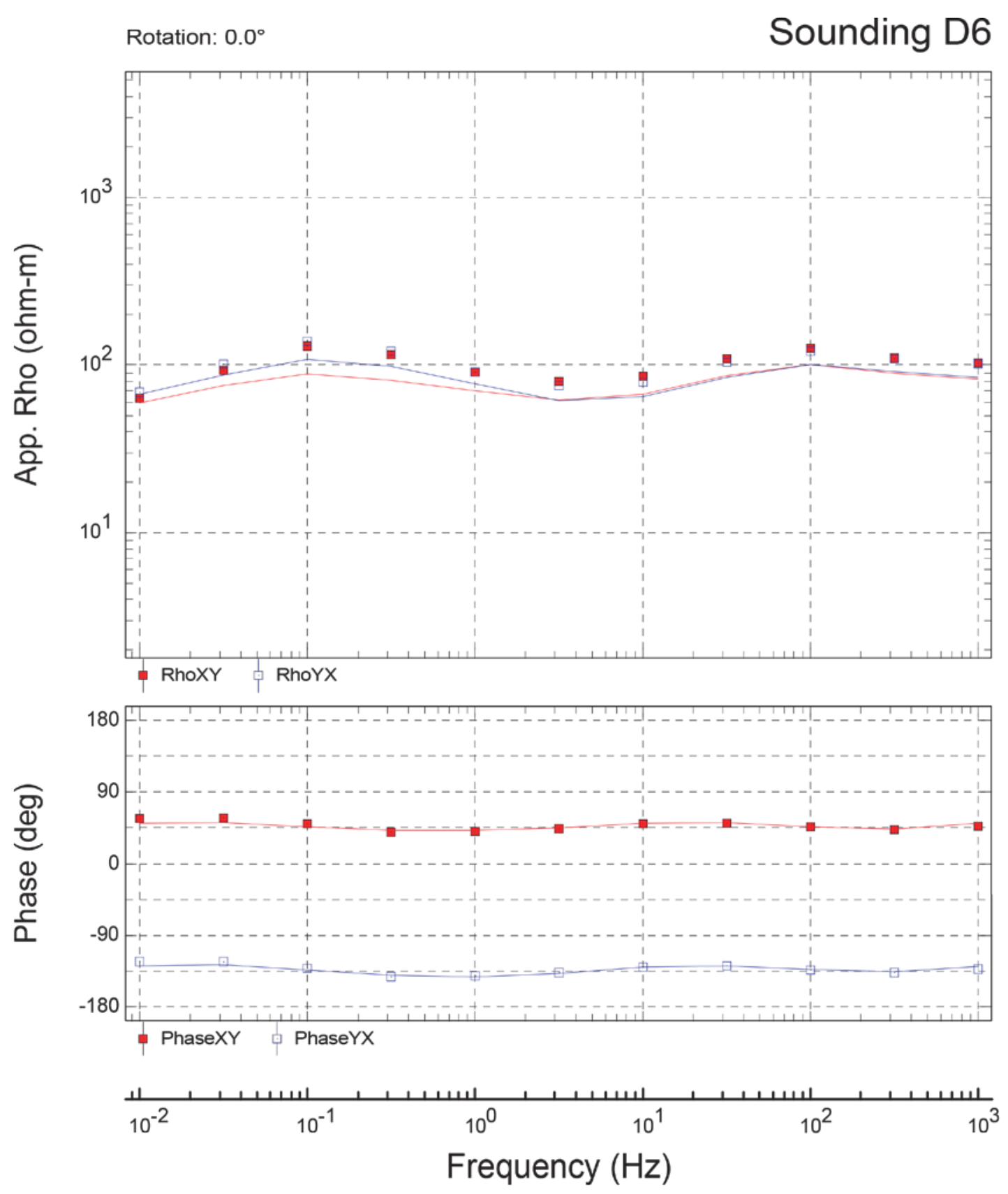

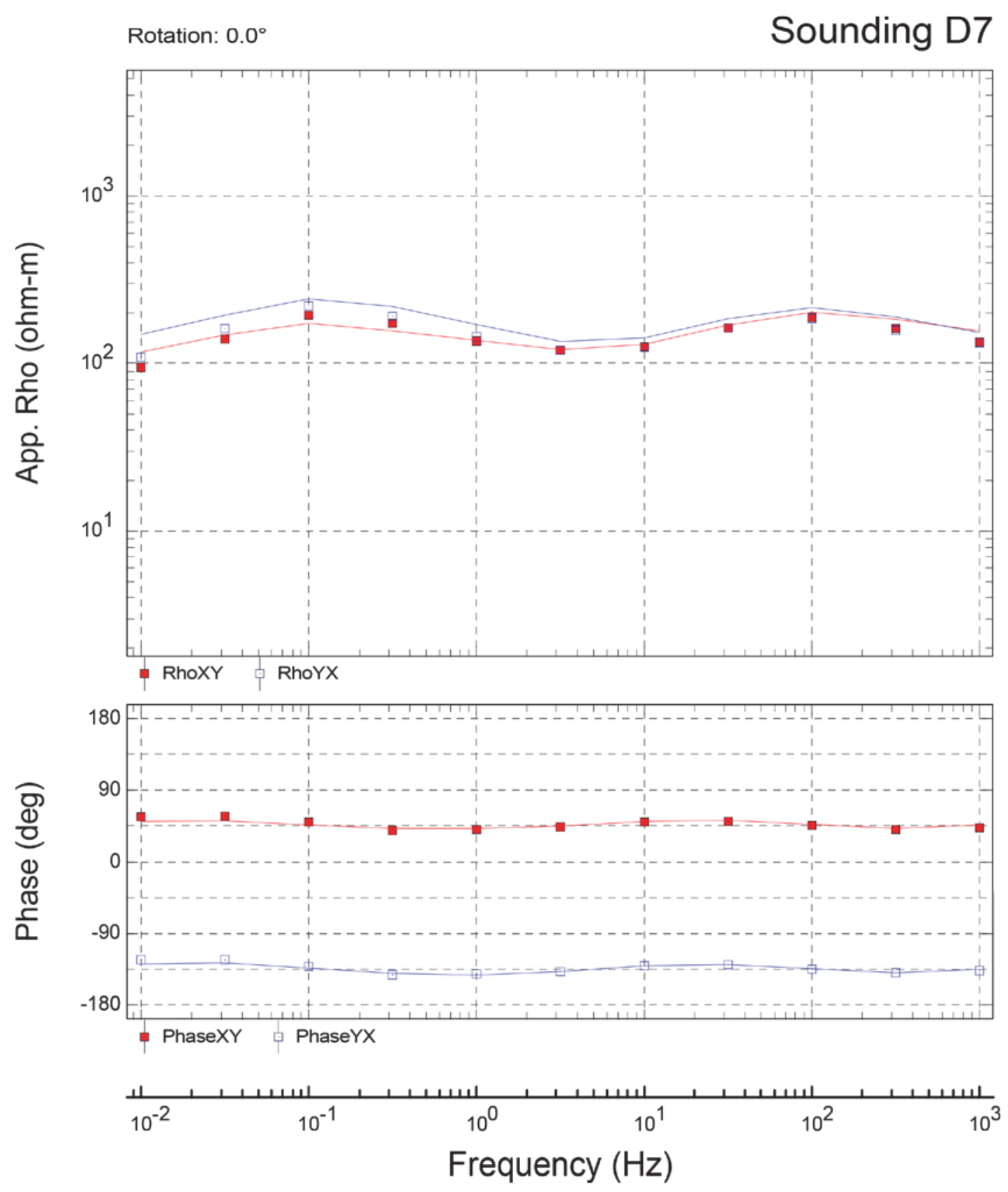

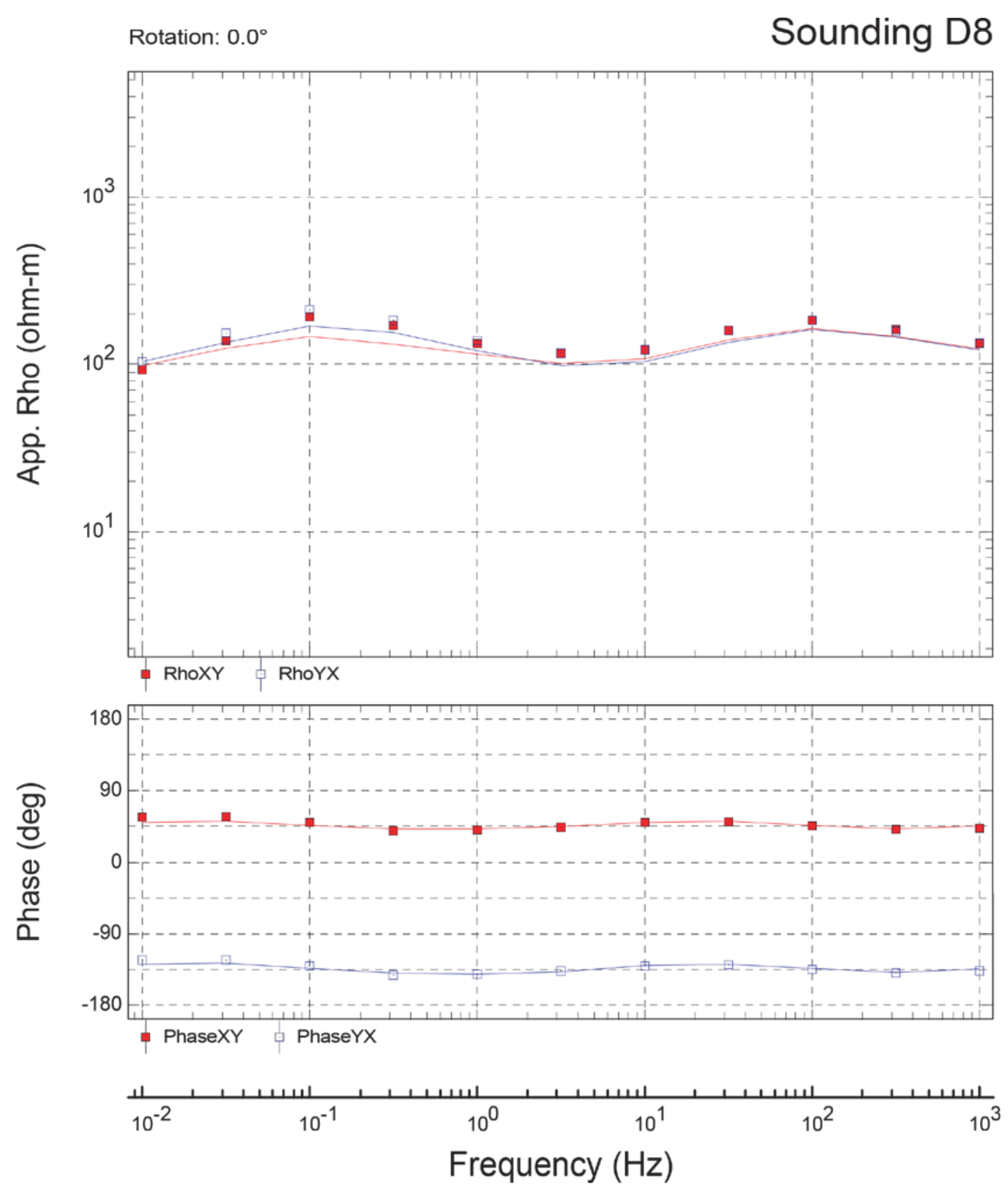

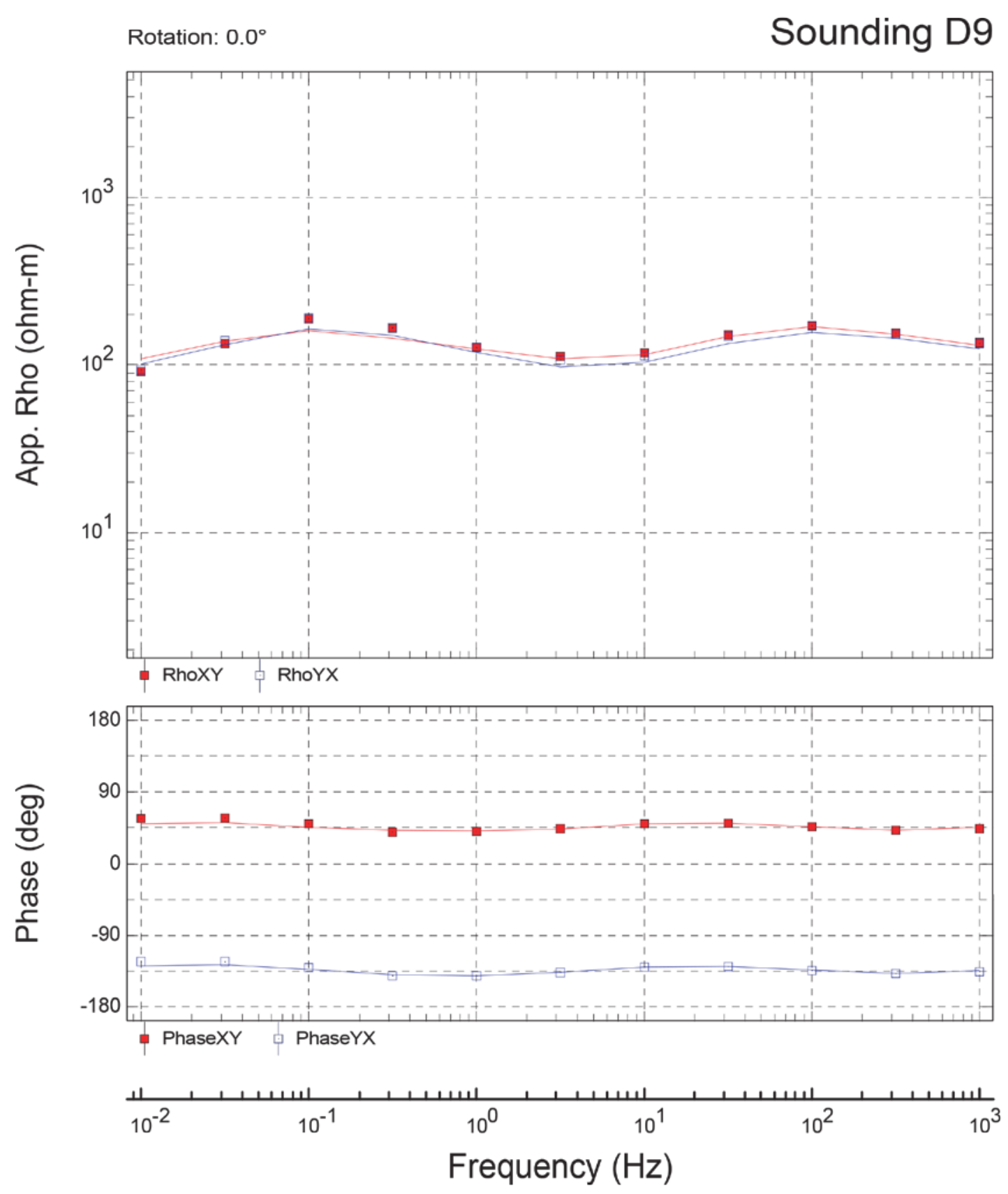

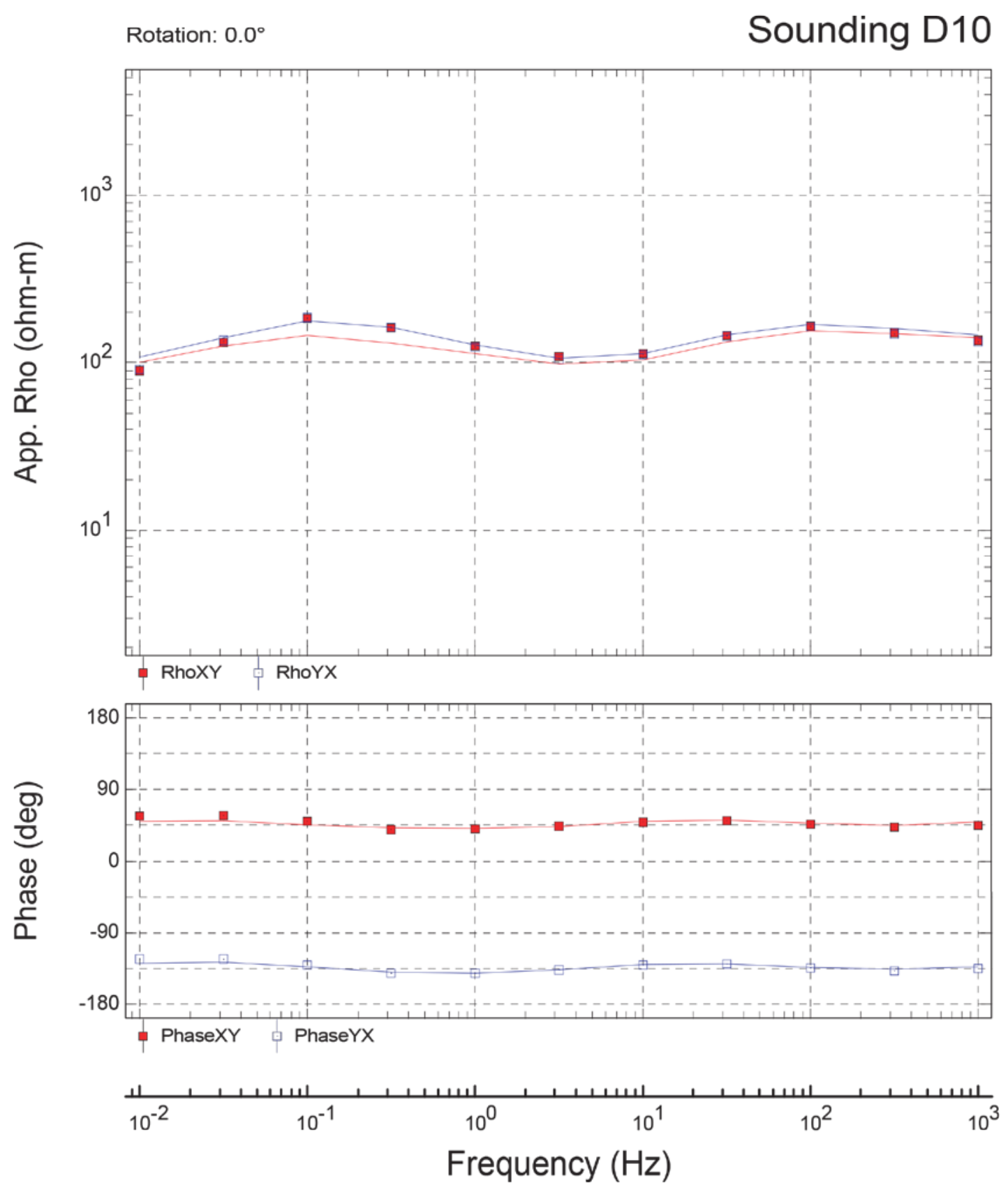

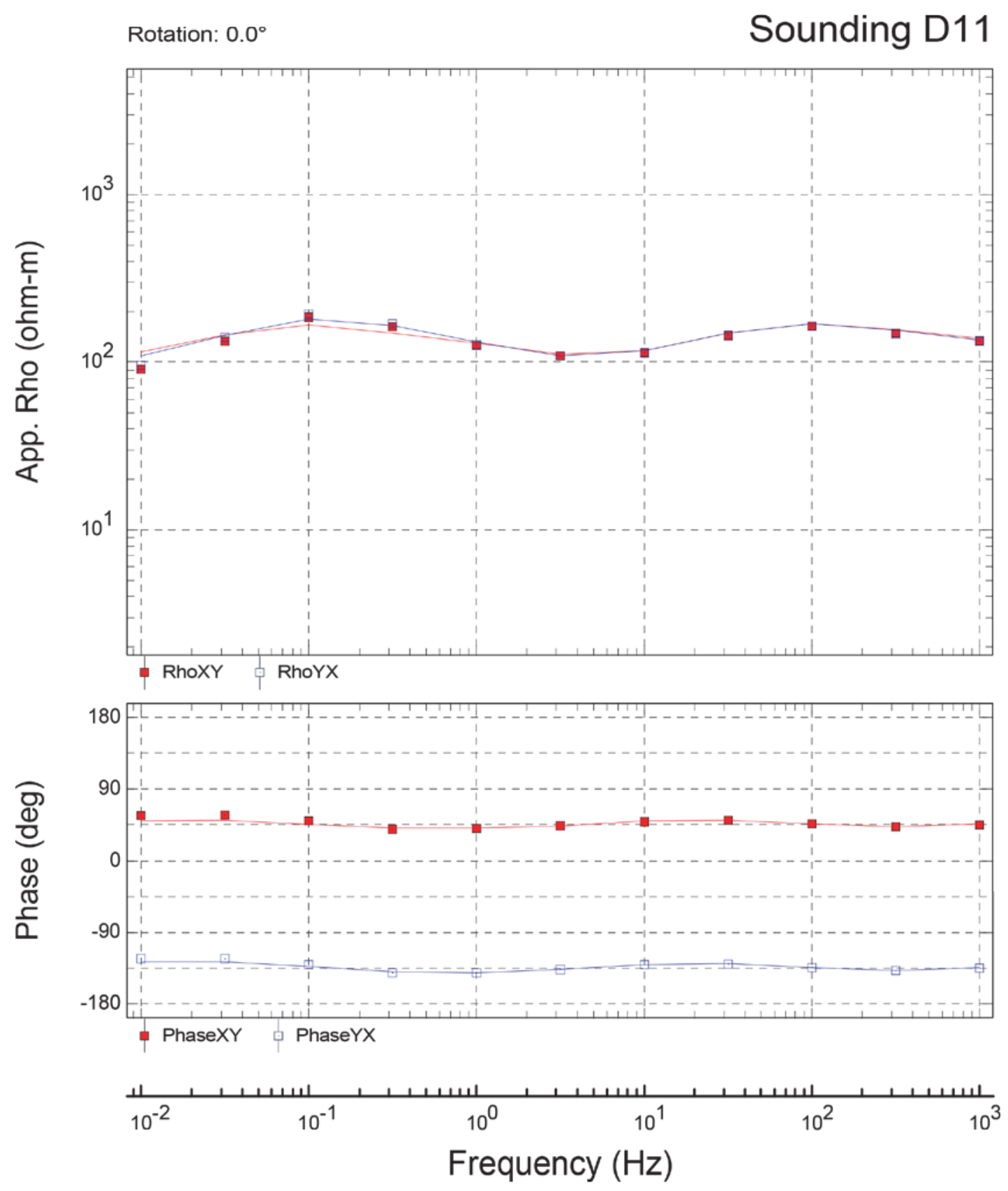

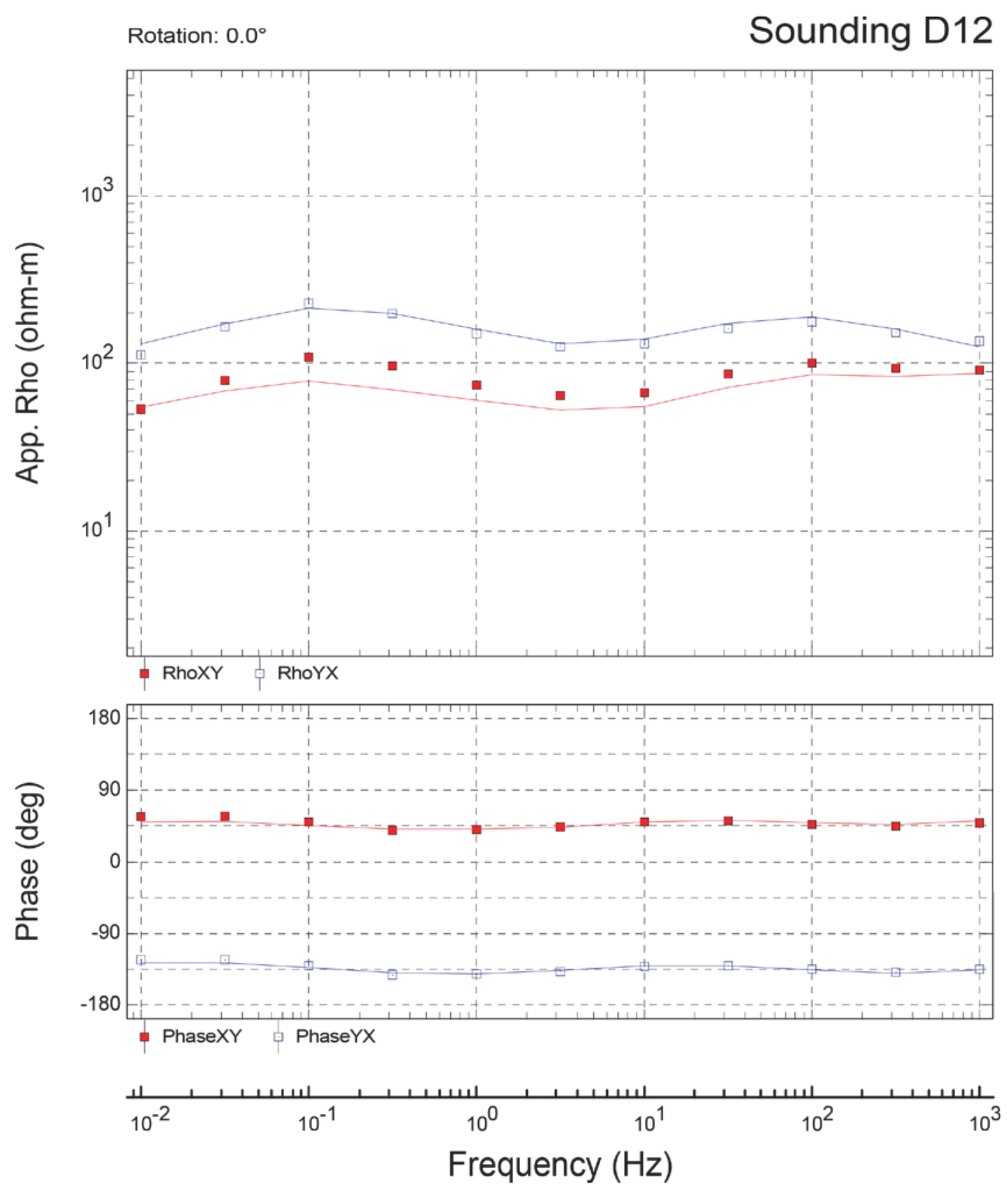

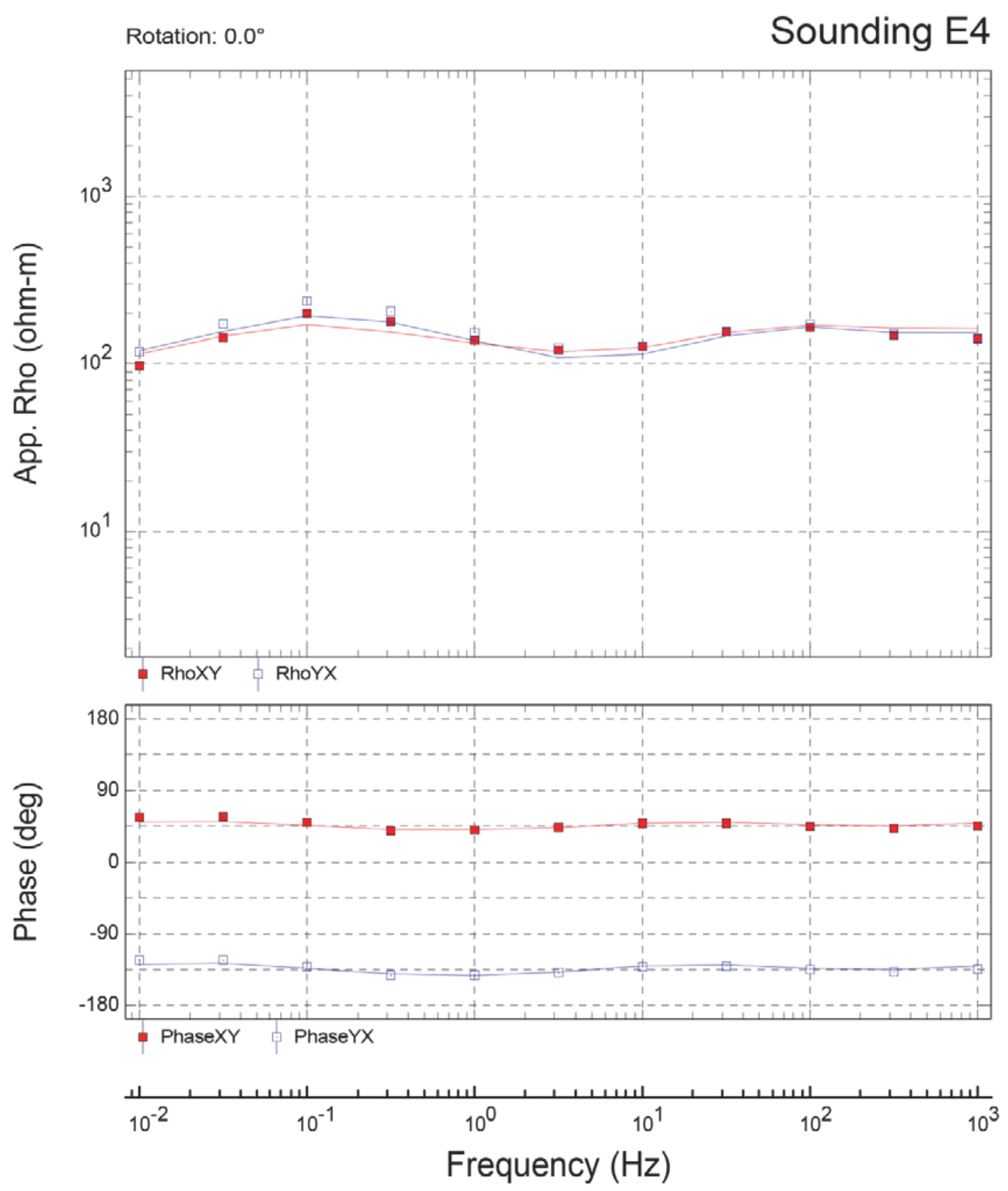

Figure 17. Soundings E4-E12. Pahute Mesa three-dimensional resistivity inversion data along profile E. All other labels, symbols, and lines are as in figure 13. 

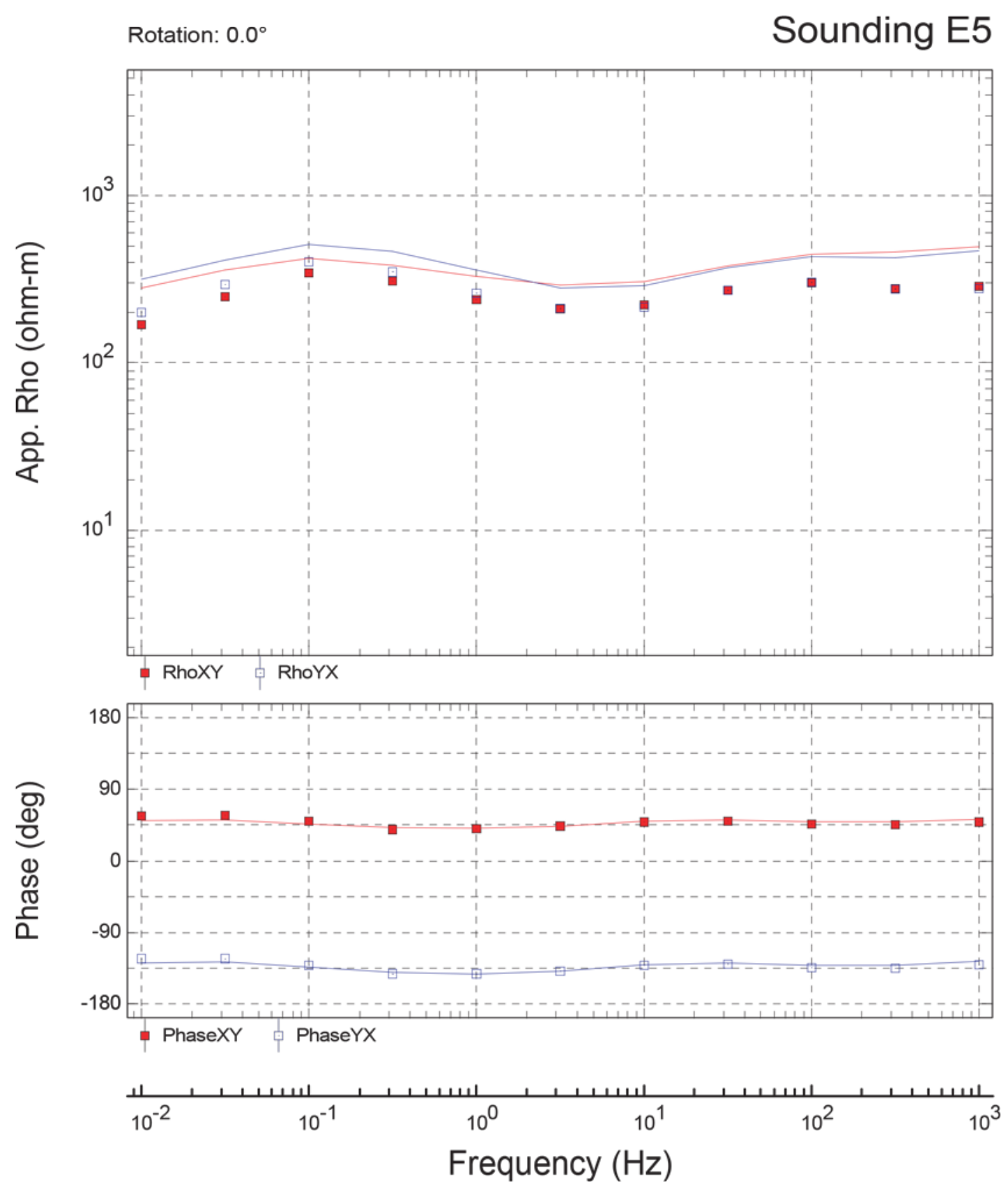


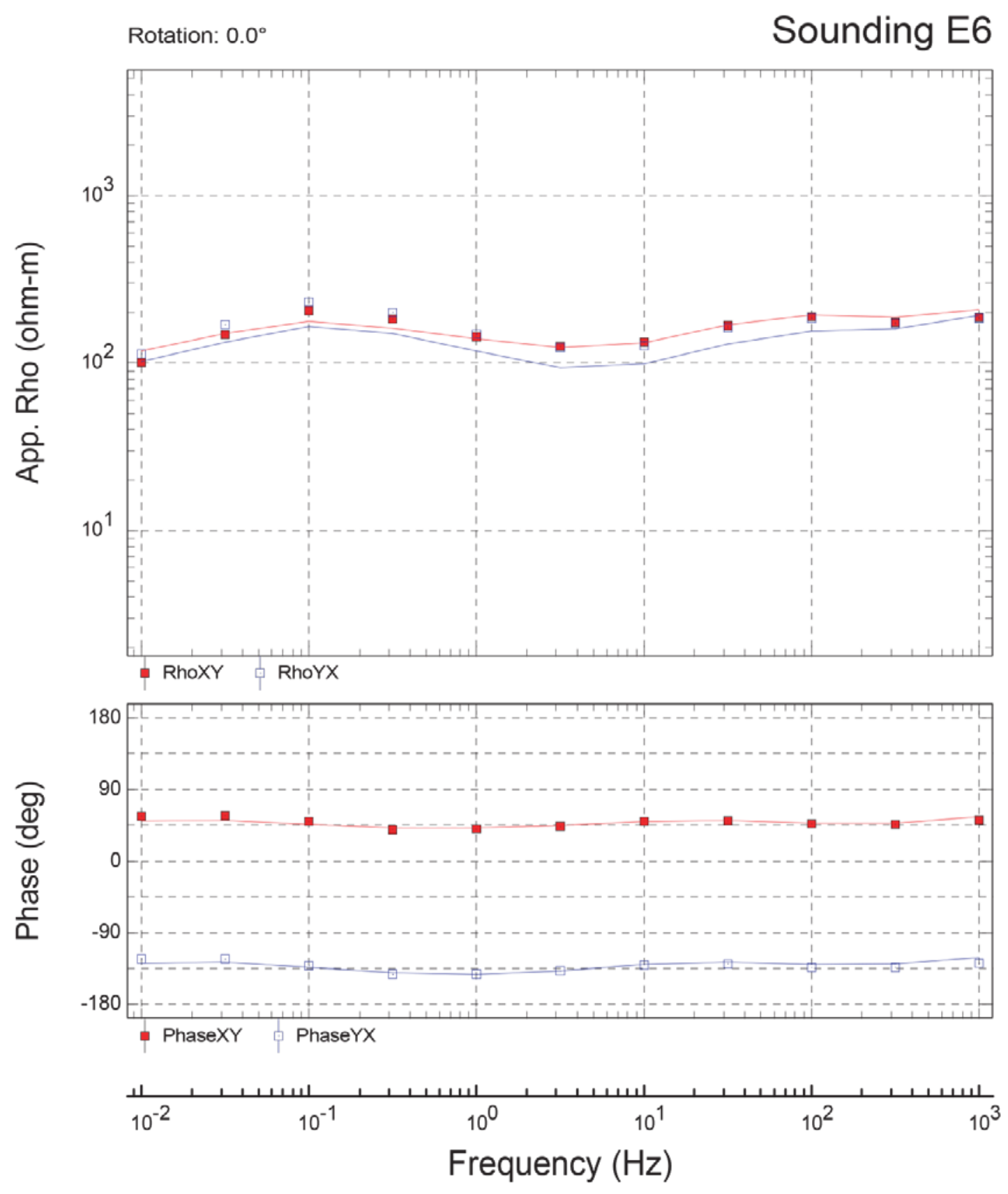



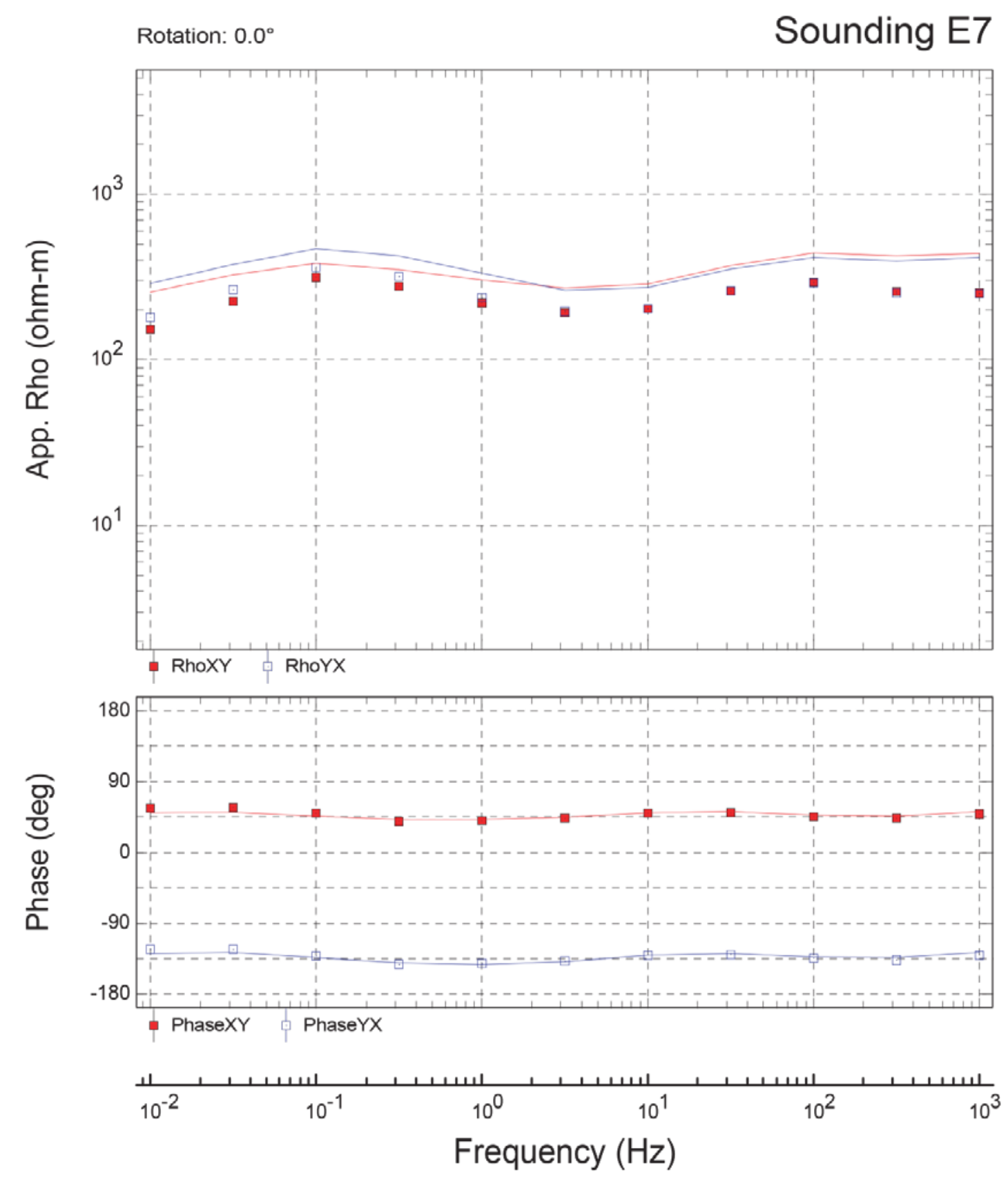


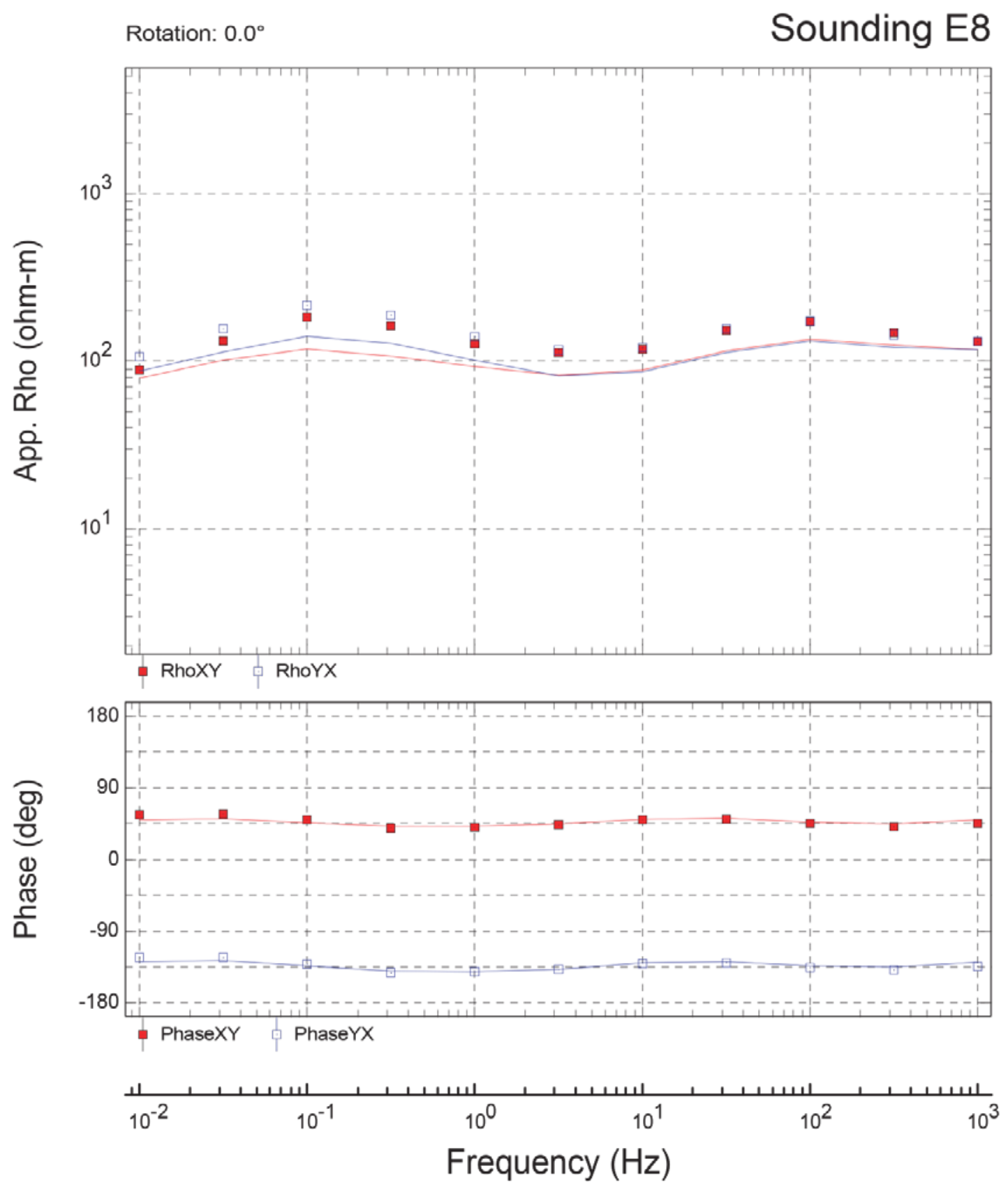




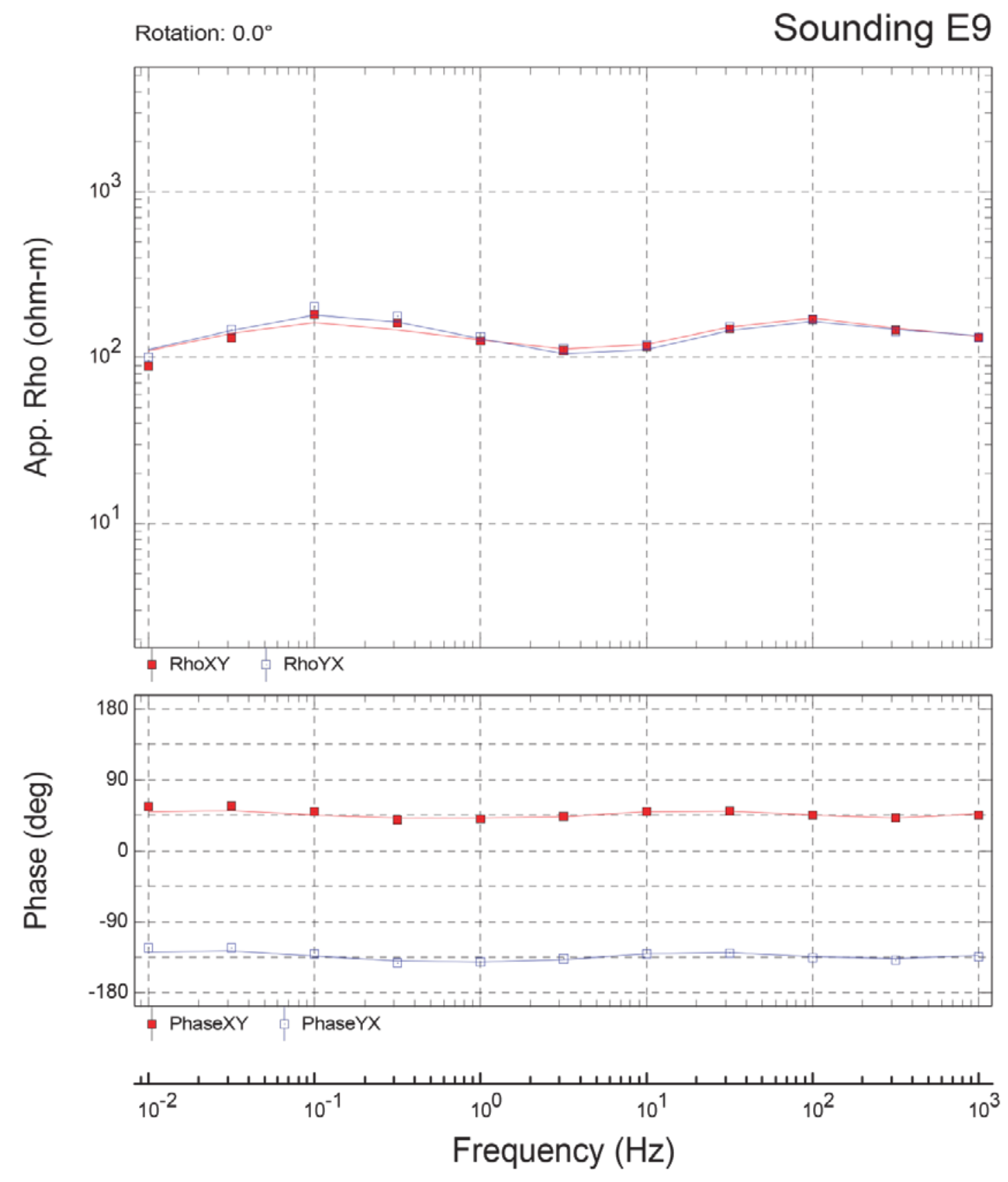




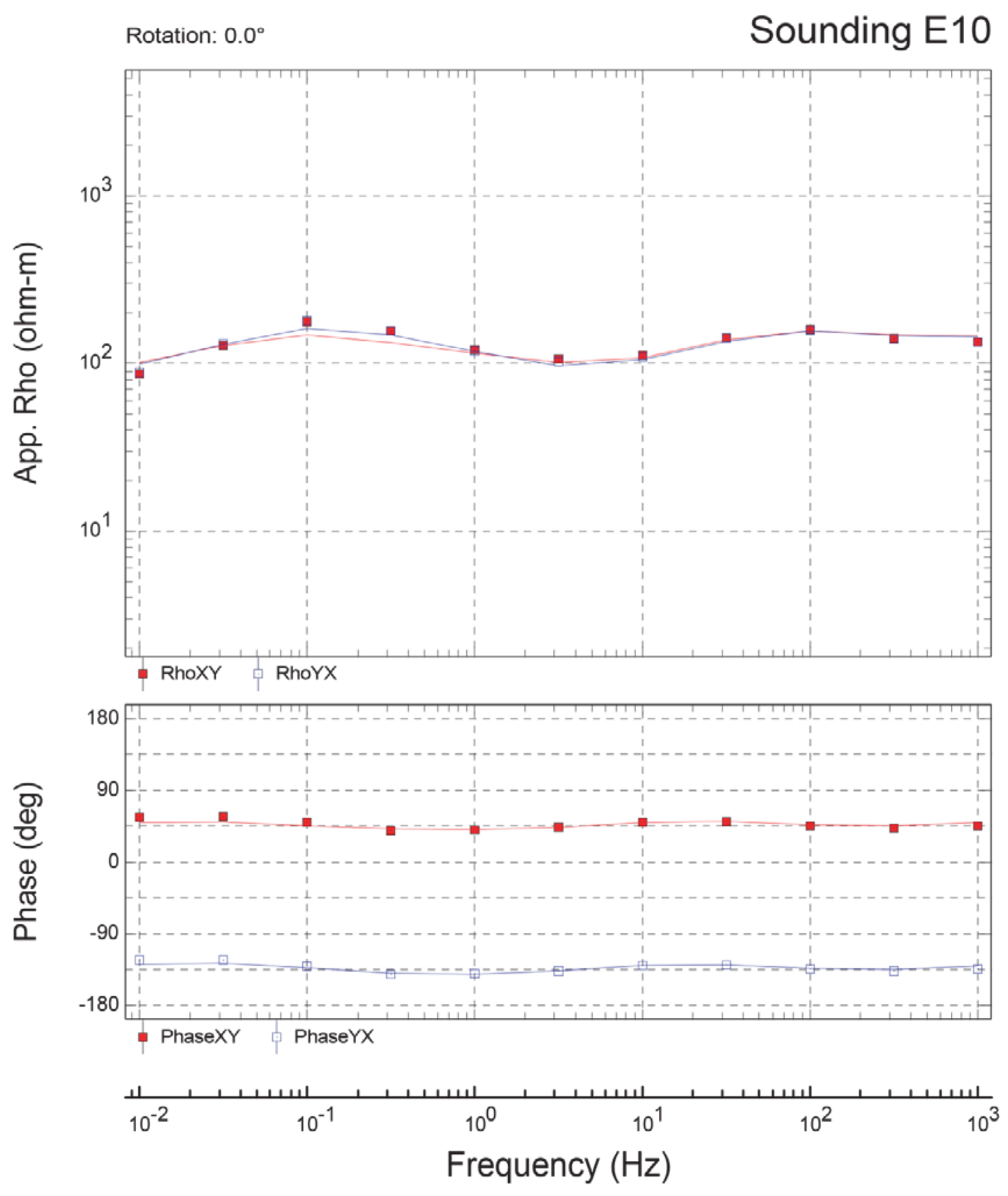



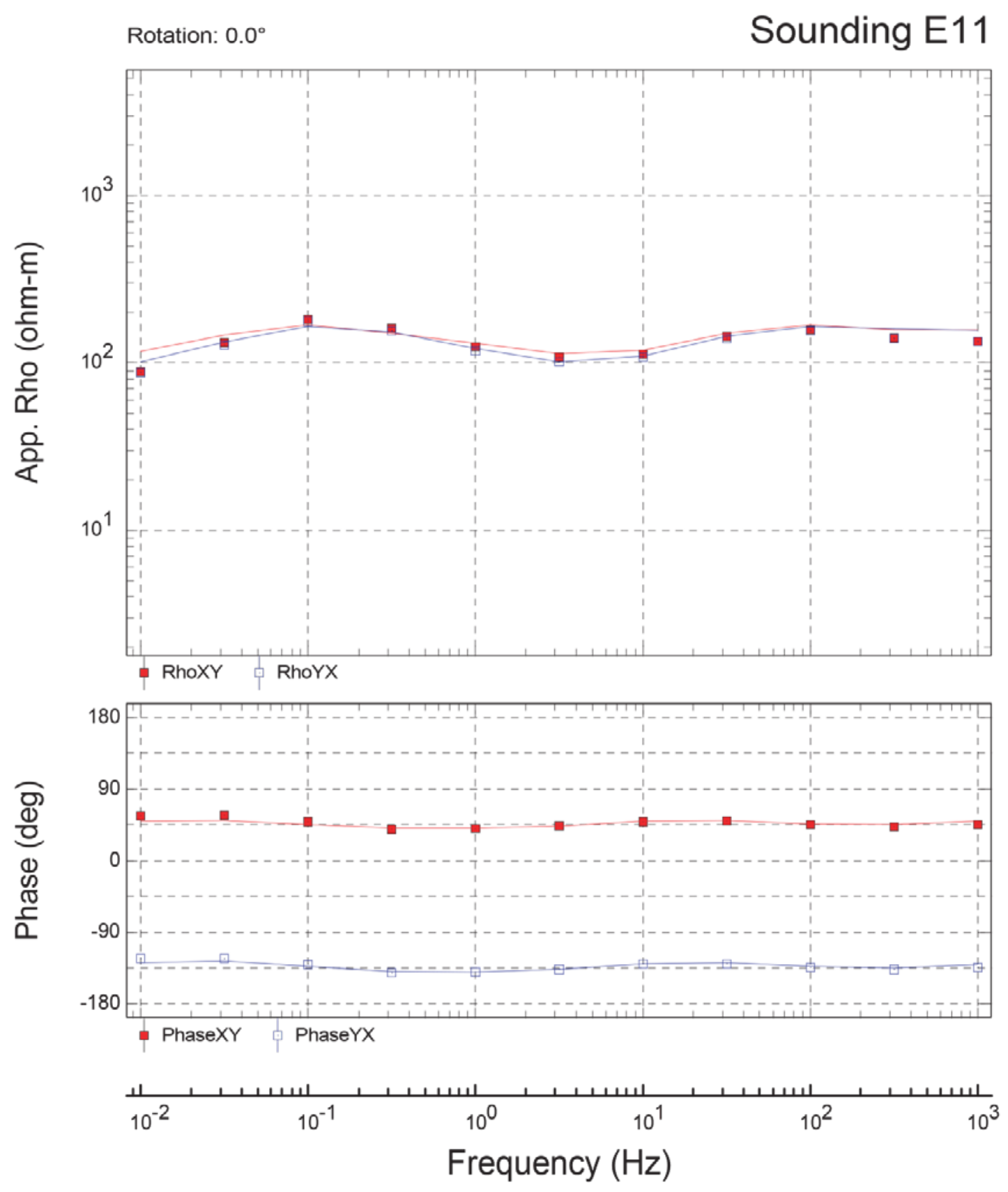

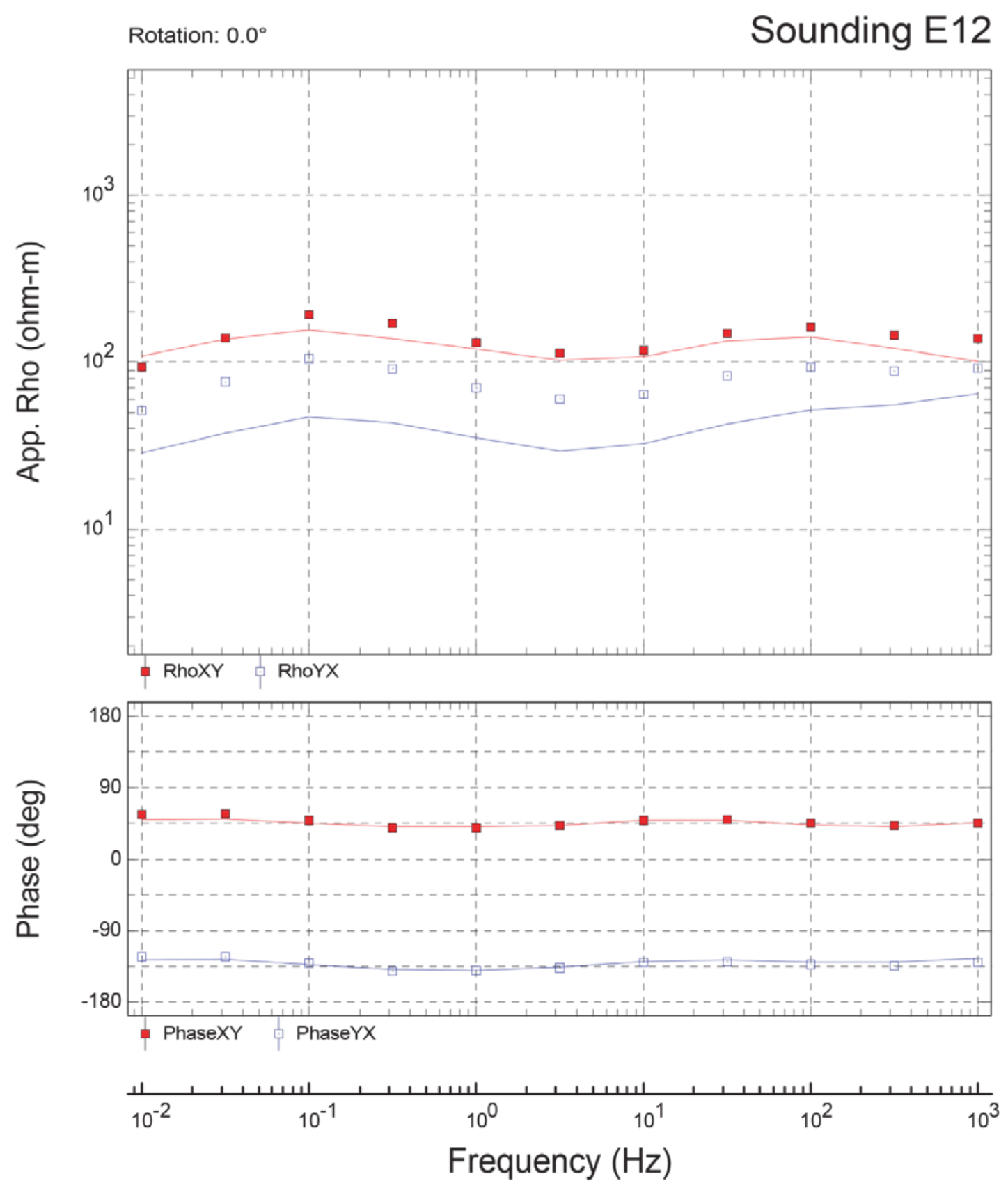

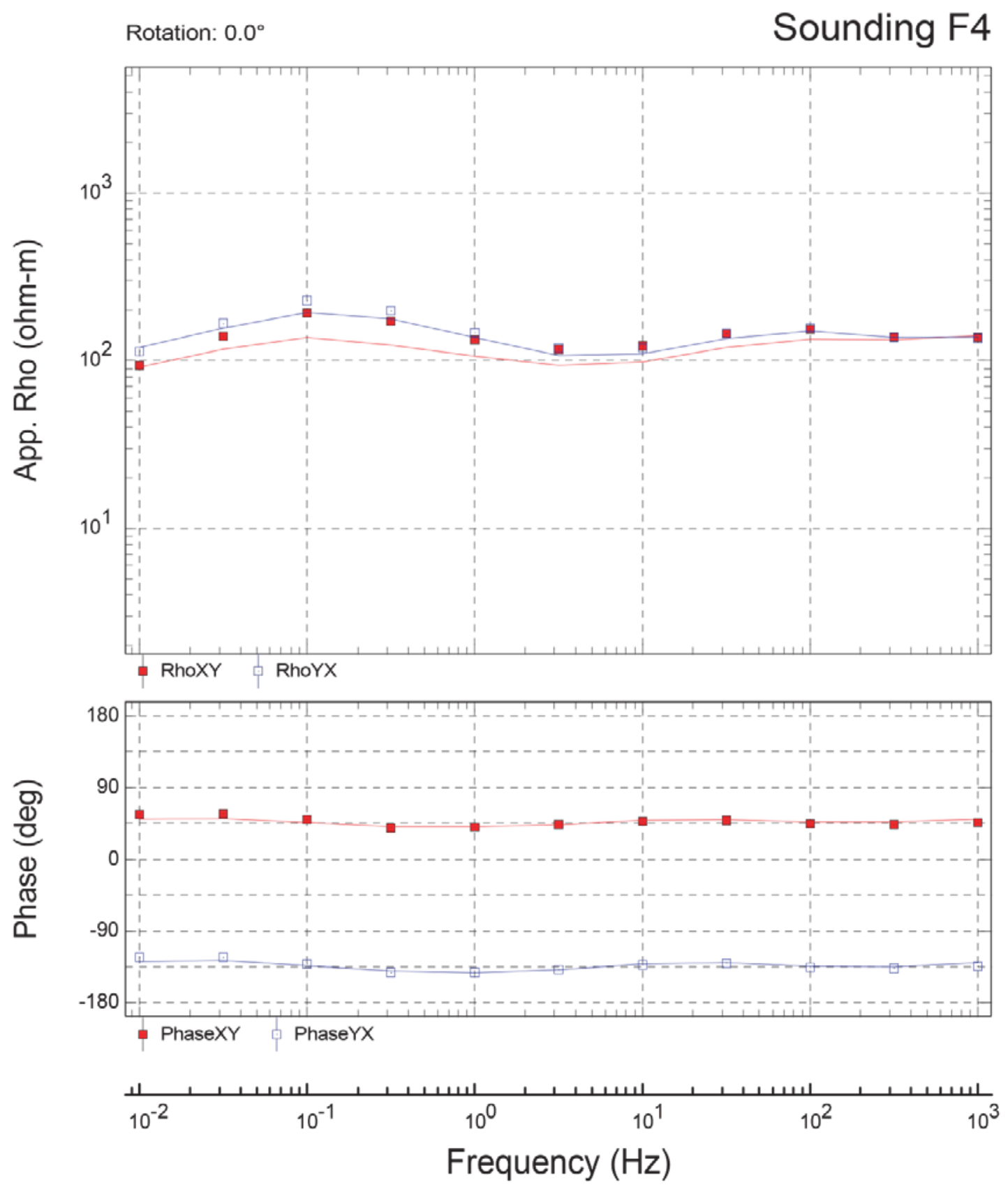

Figure 18. Soundings F4-F12. Pahute Mesa three-dimensional resistivity inversion data along profile F. All other labels, symbols, and lines are as in figure 13. 

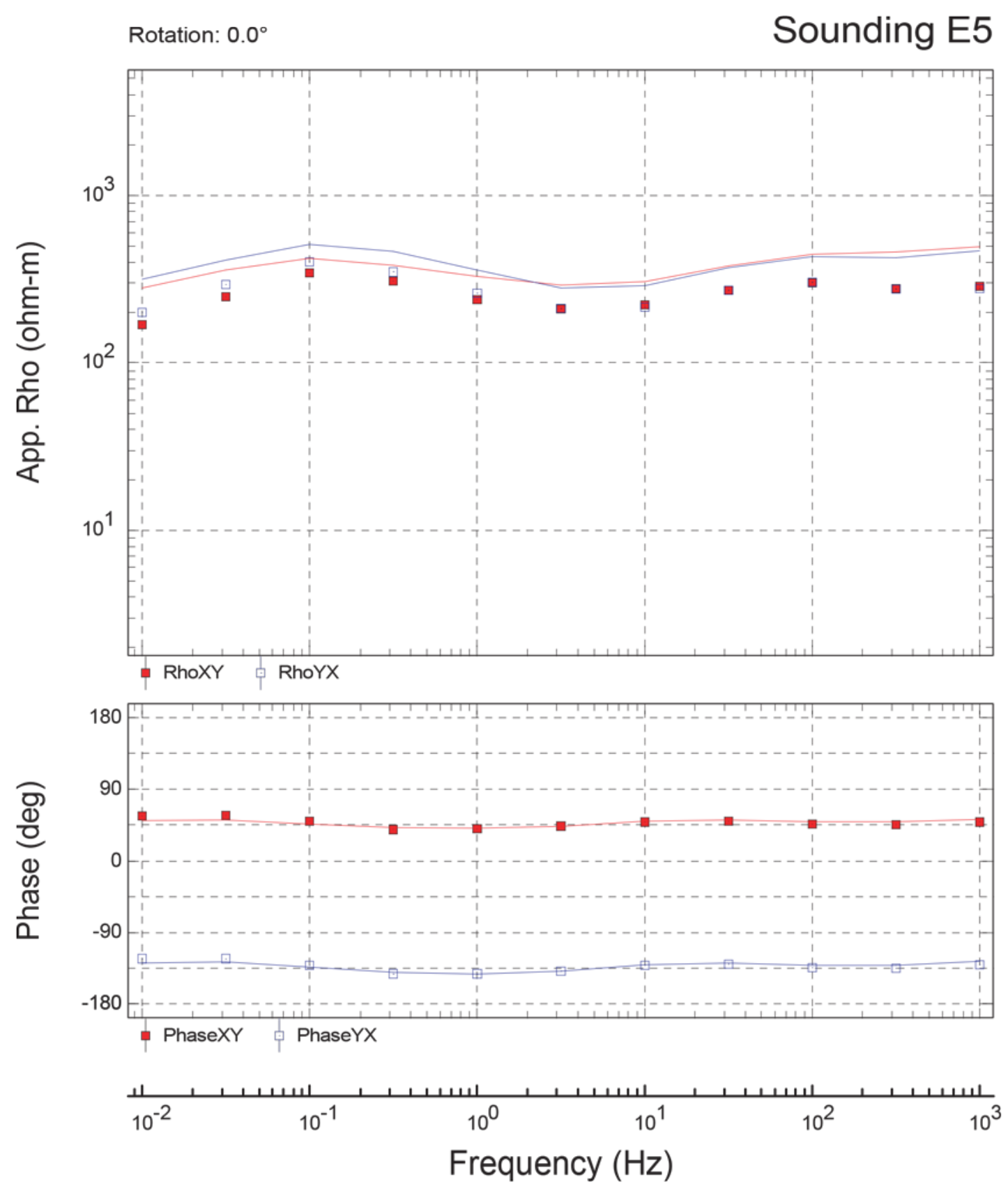


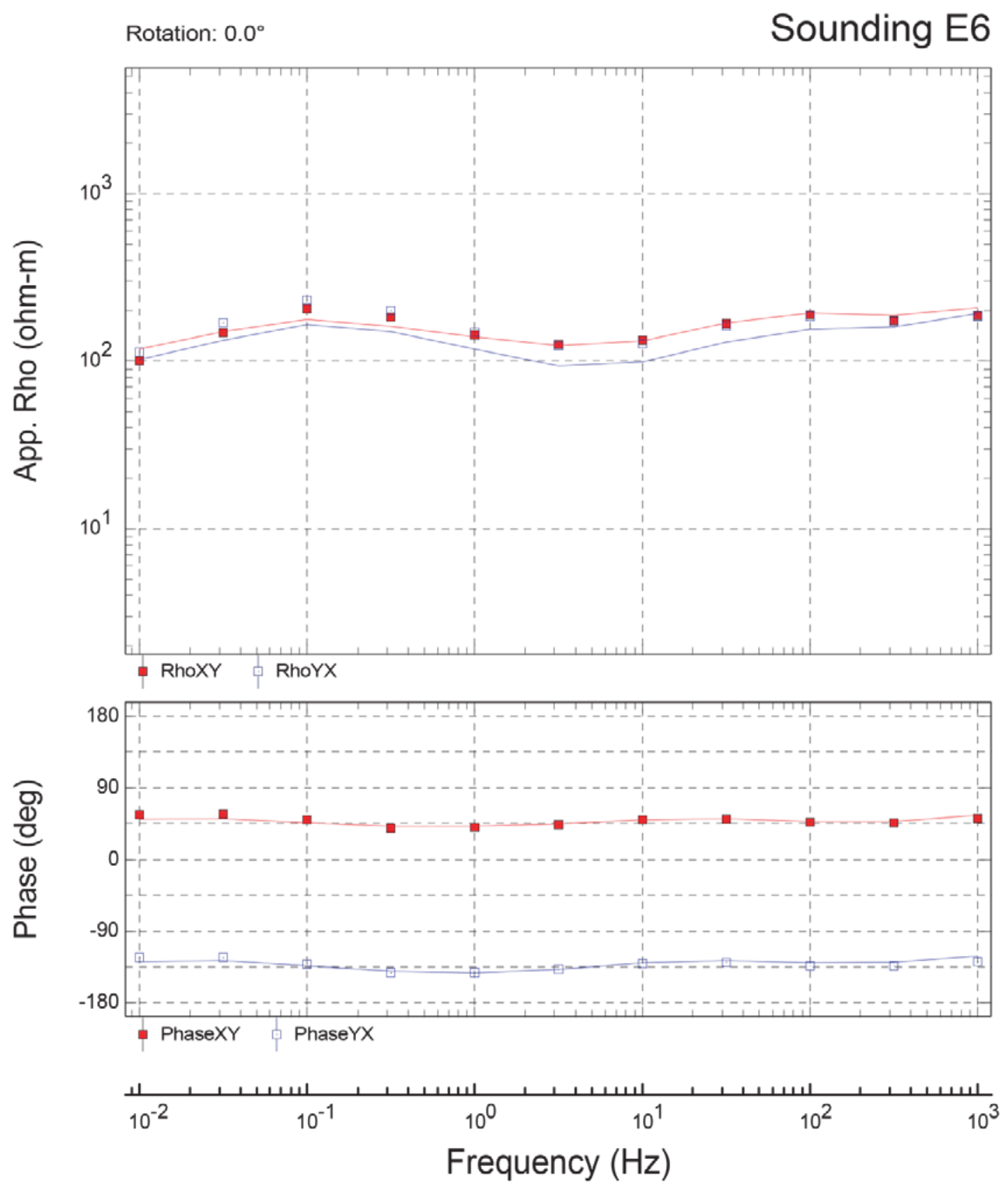



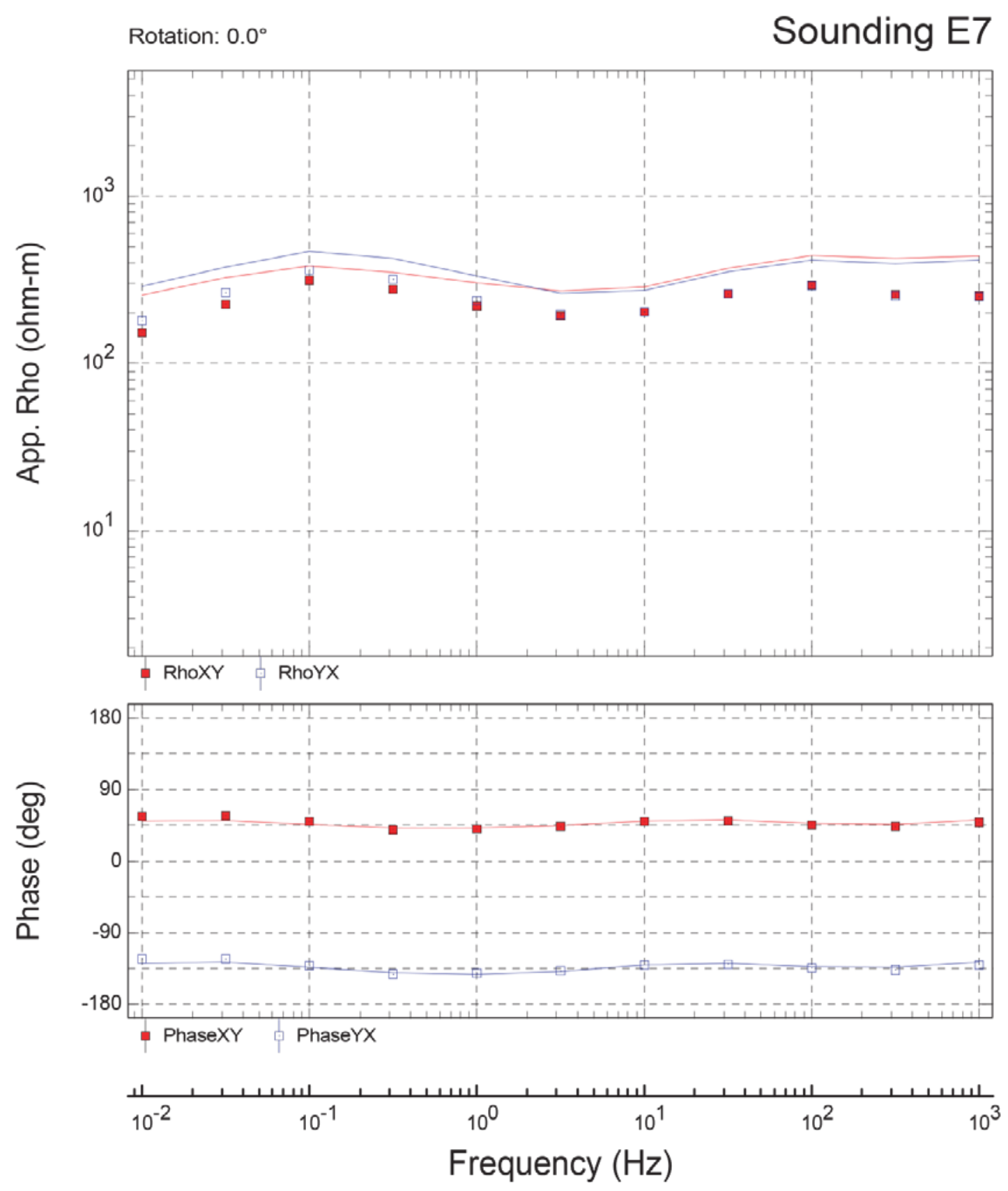


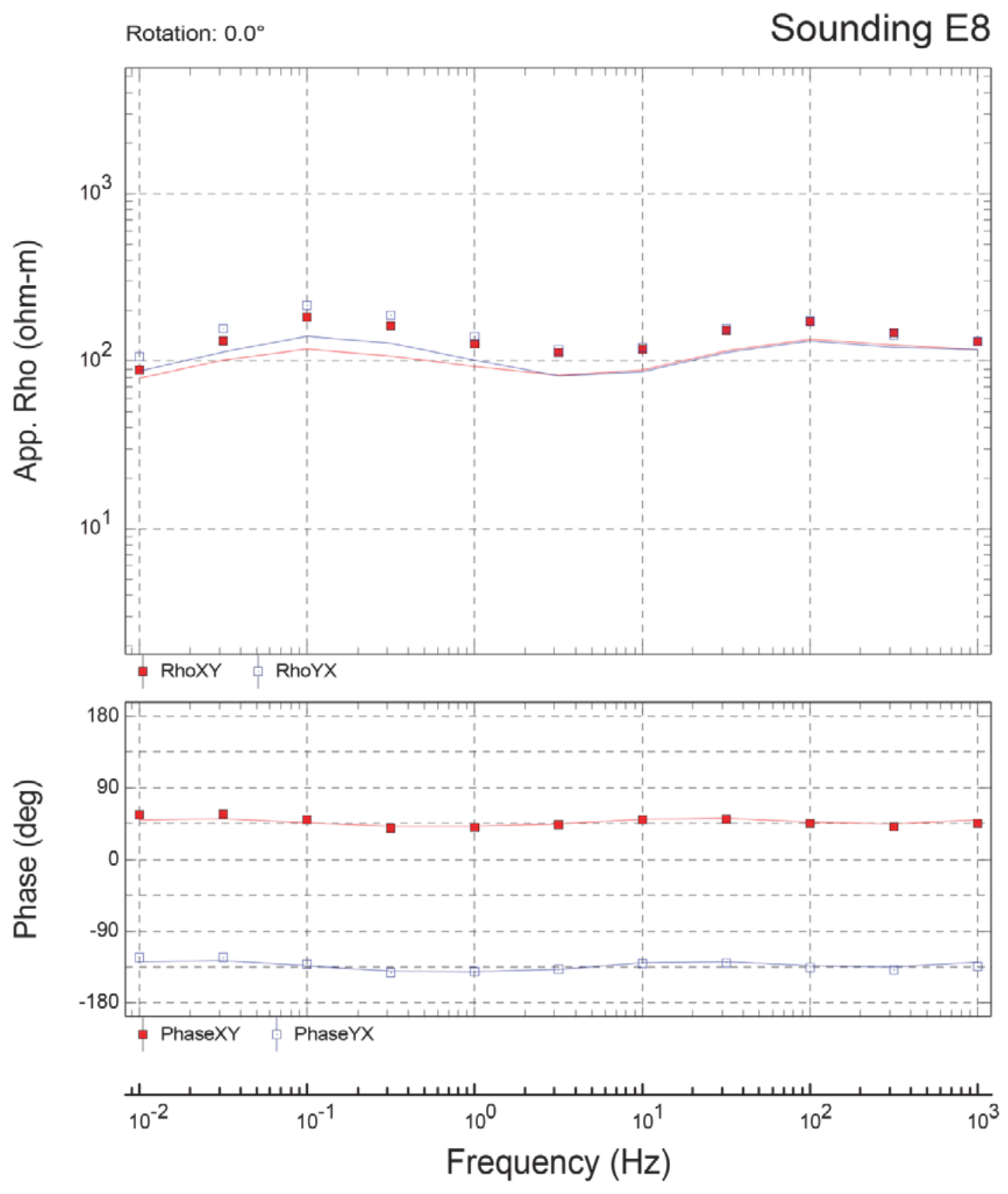




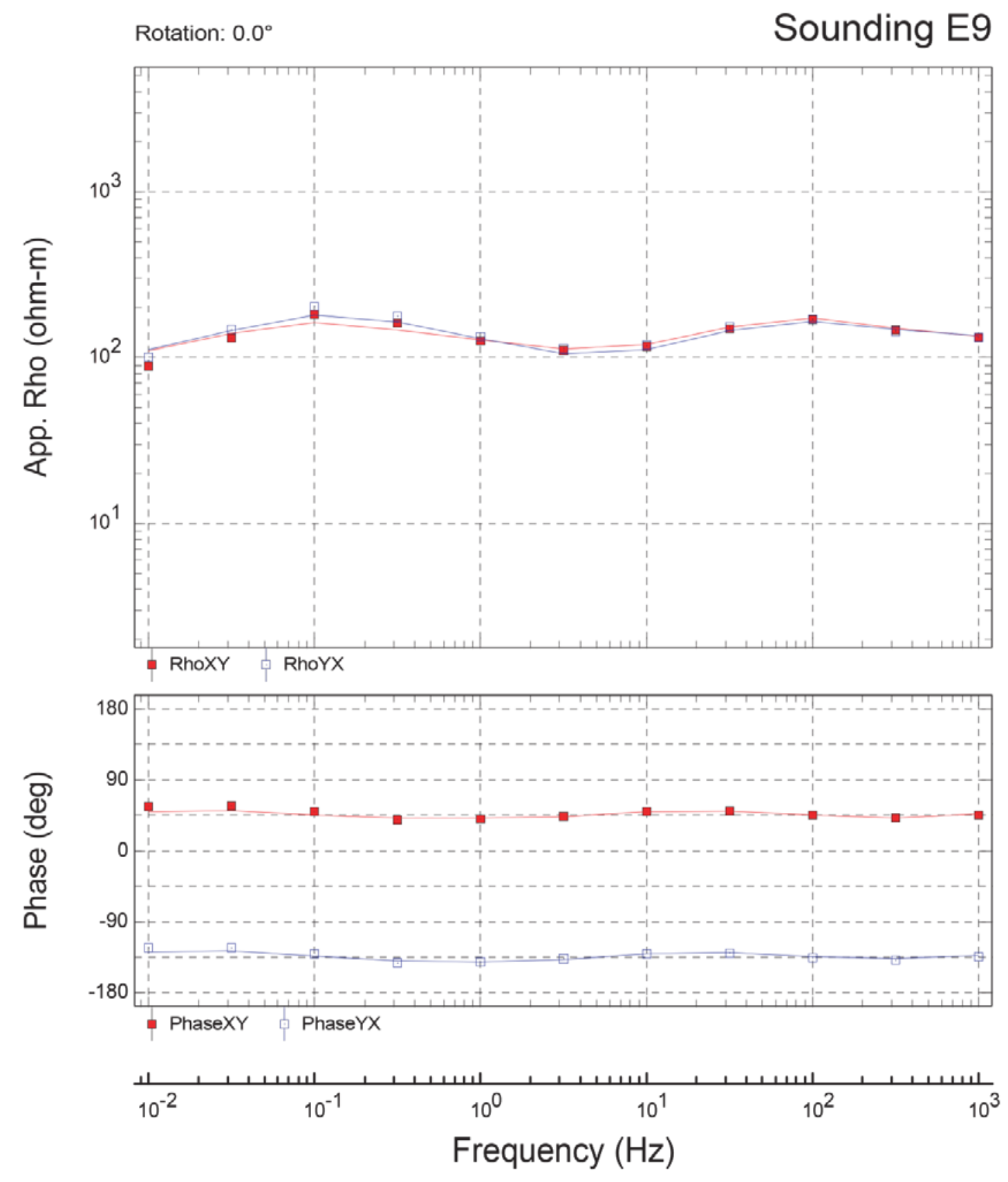




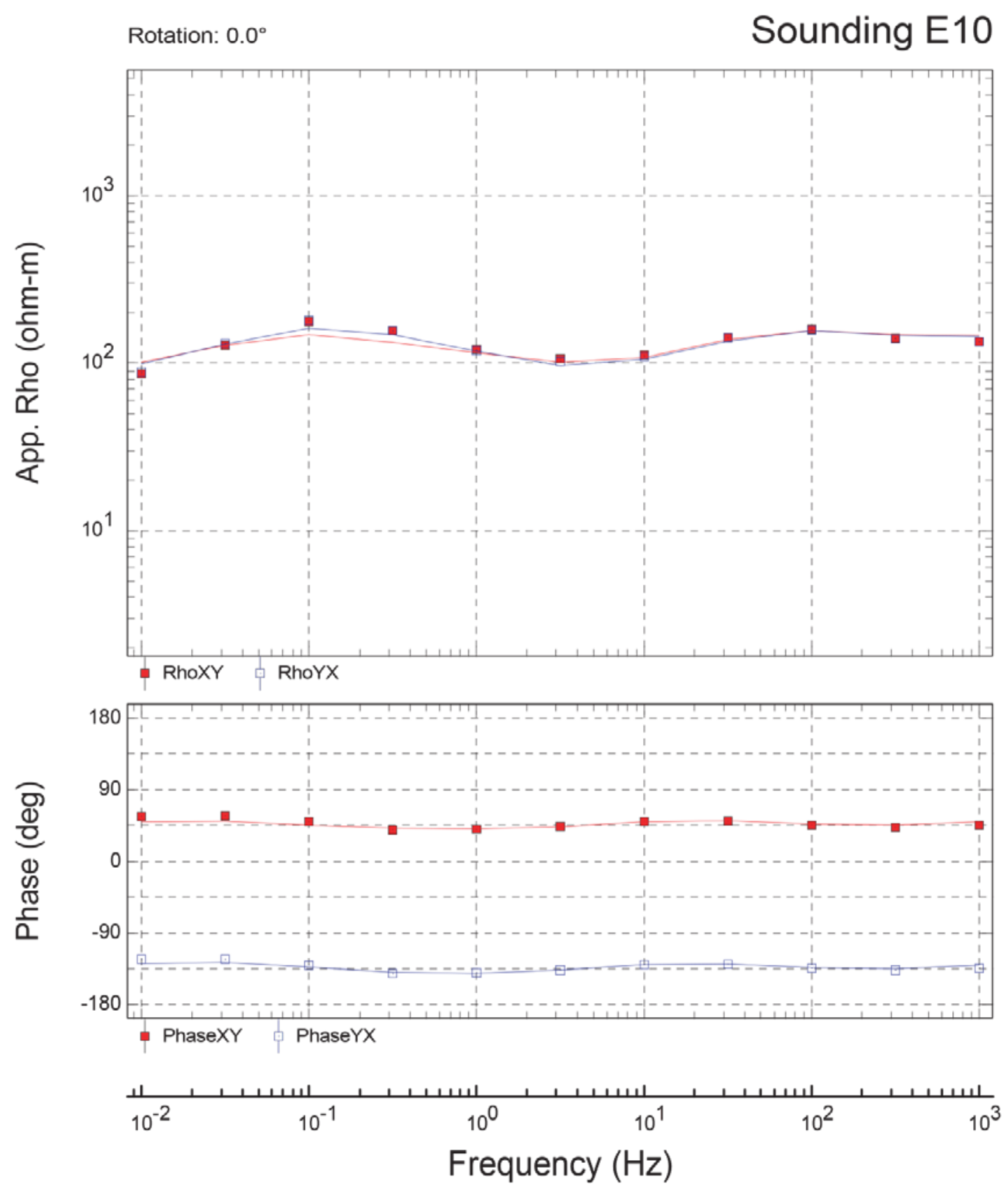



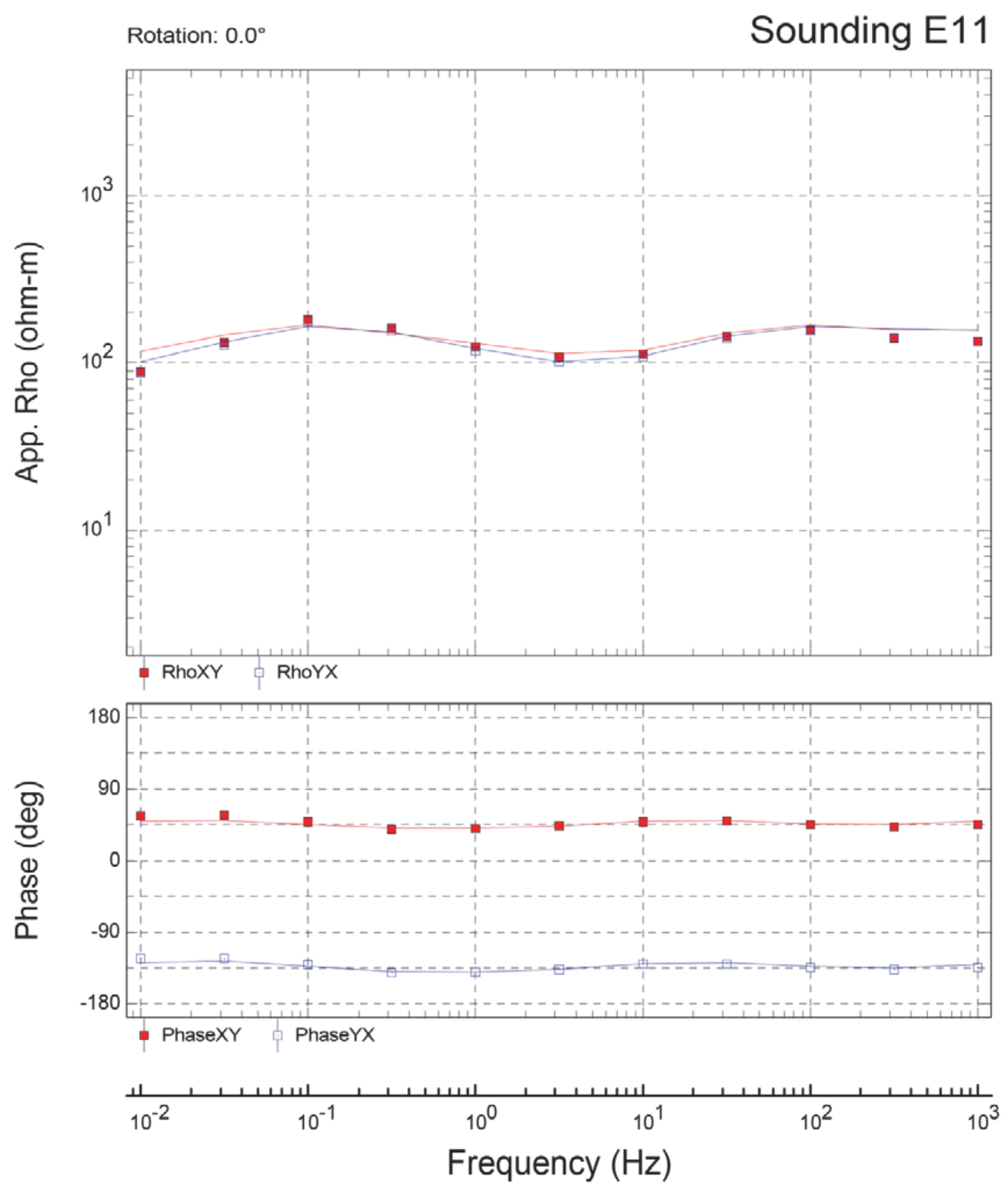

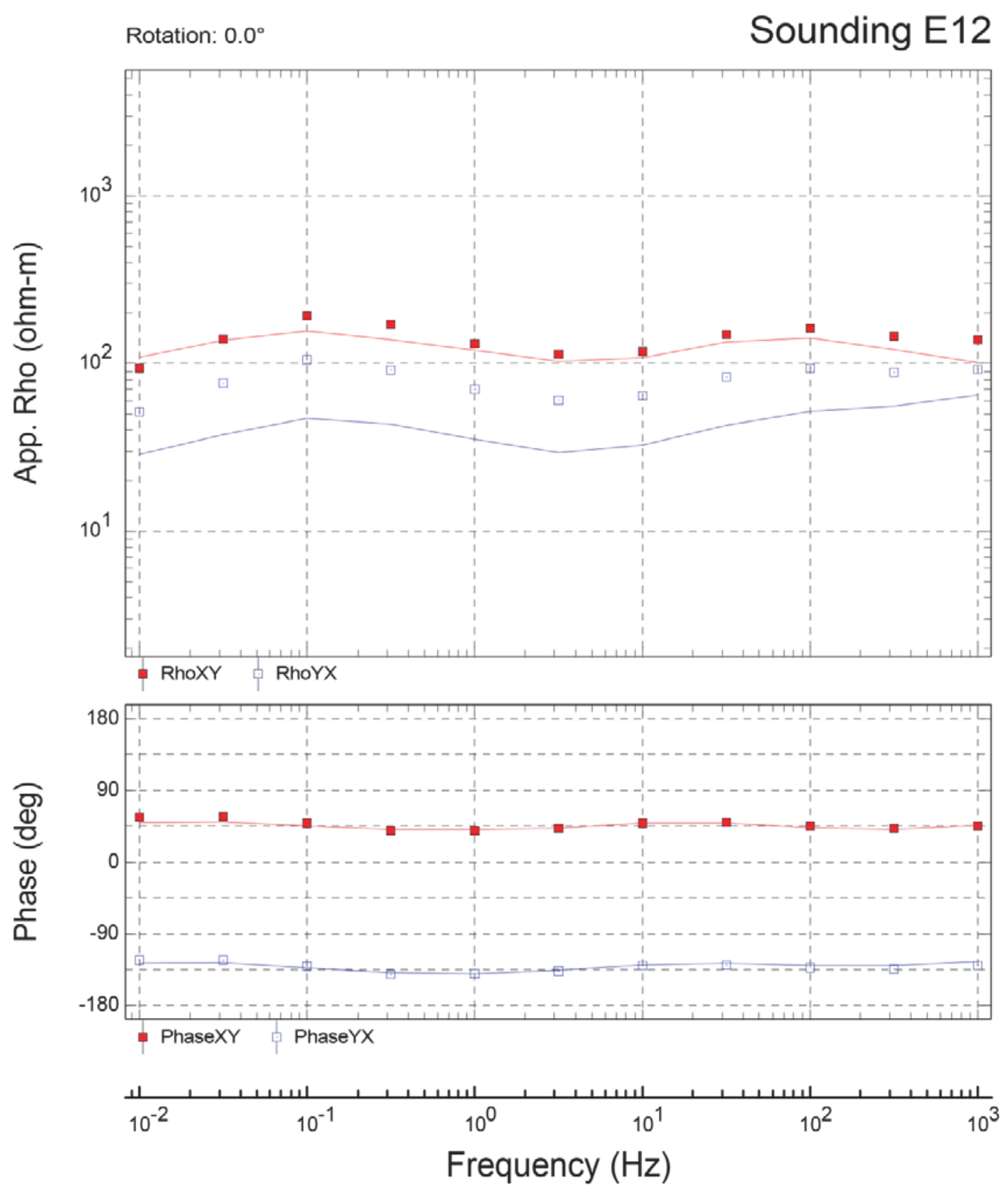

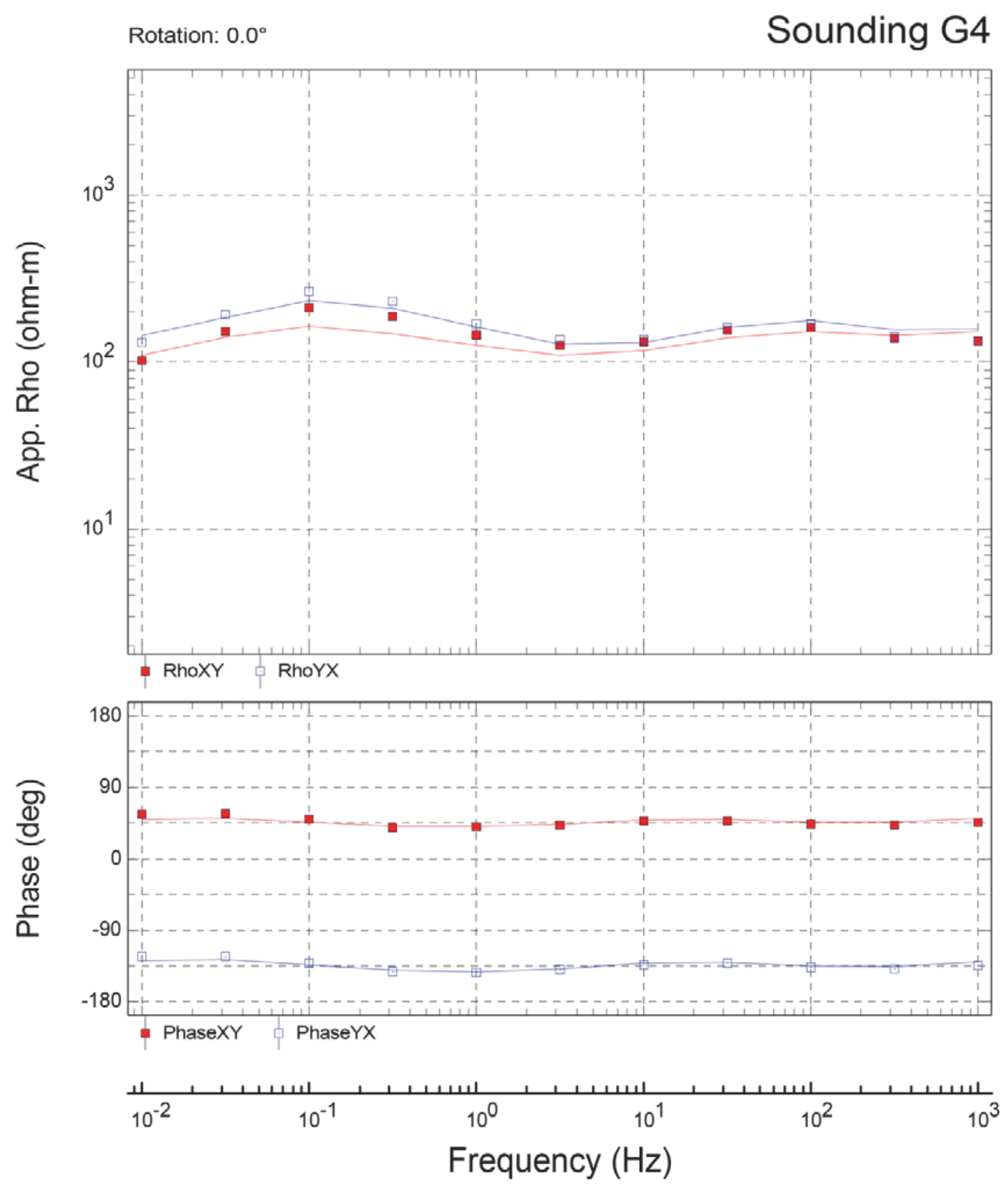

Figure 19. Soundings G4-G12. Pahute Mesa three-dimensional resistivity inversion data along profile G. All other labels, symbols, and lines are as in figure 13. 


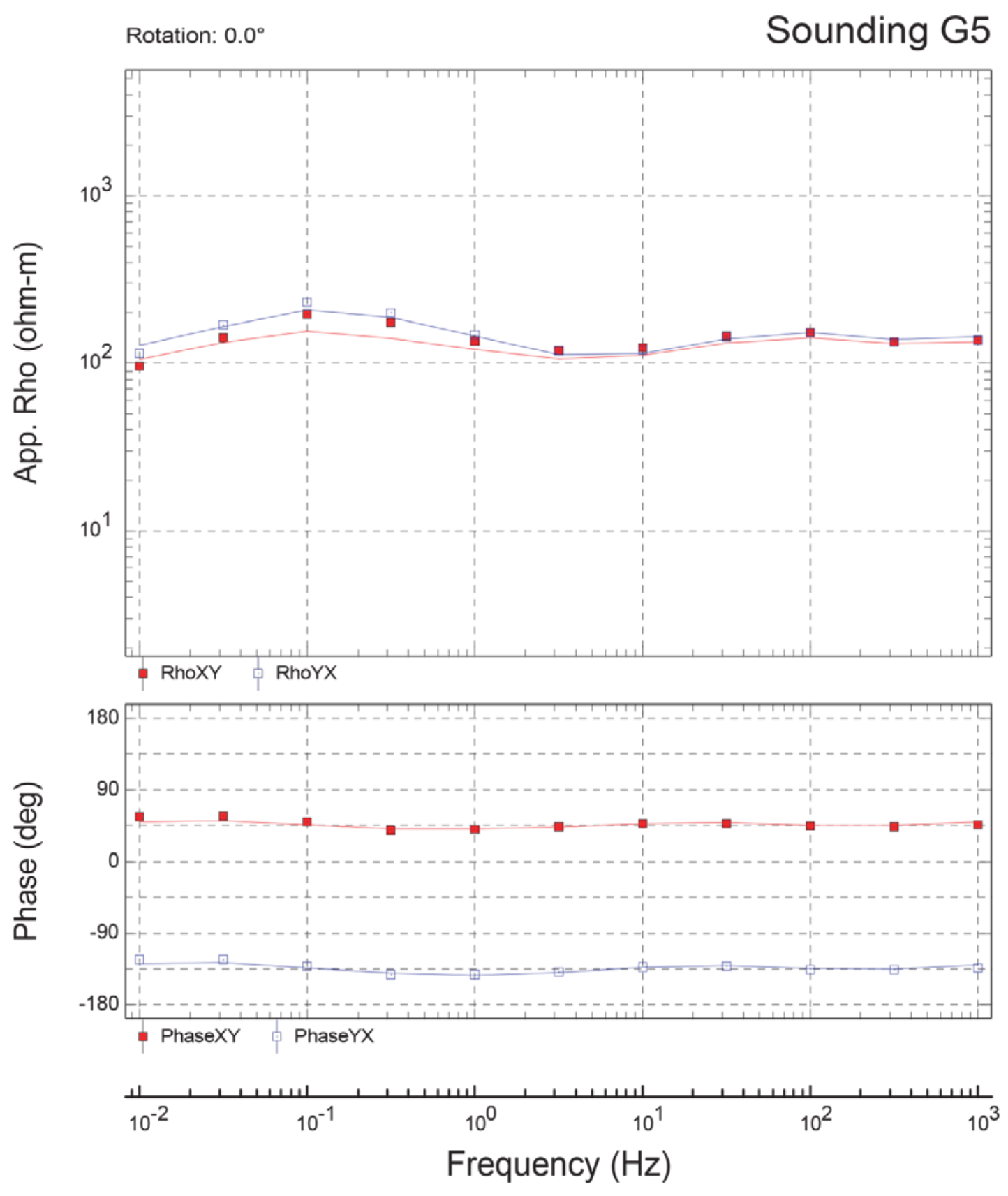




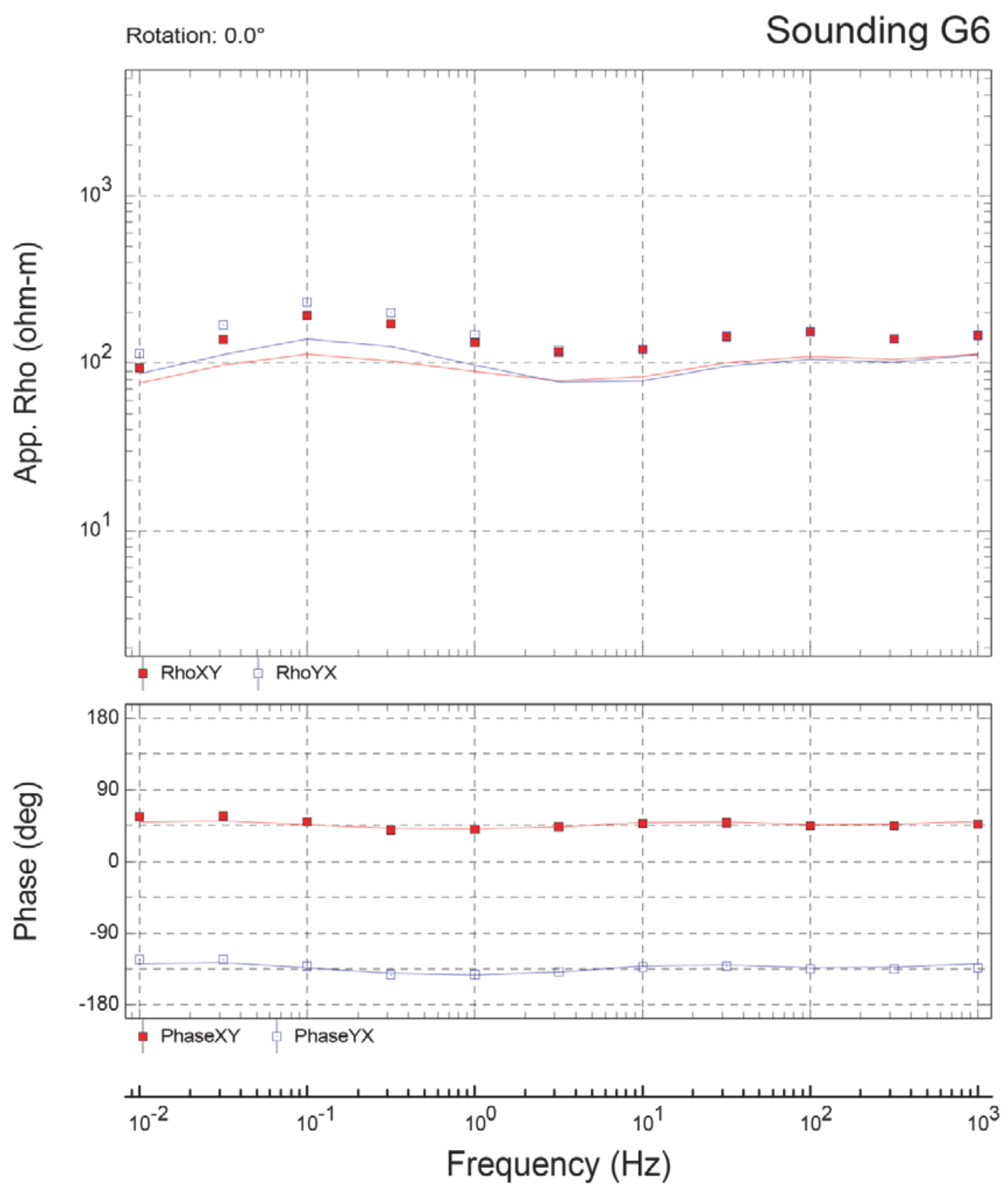



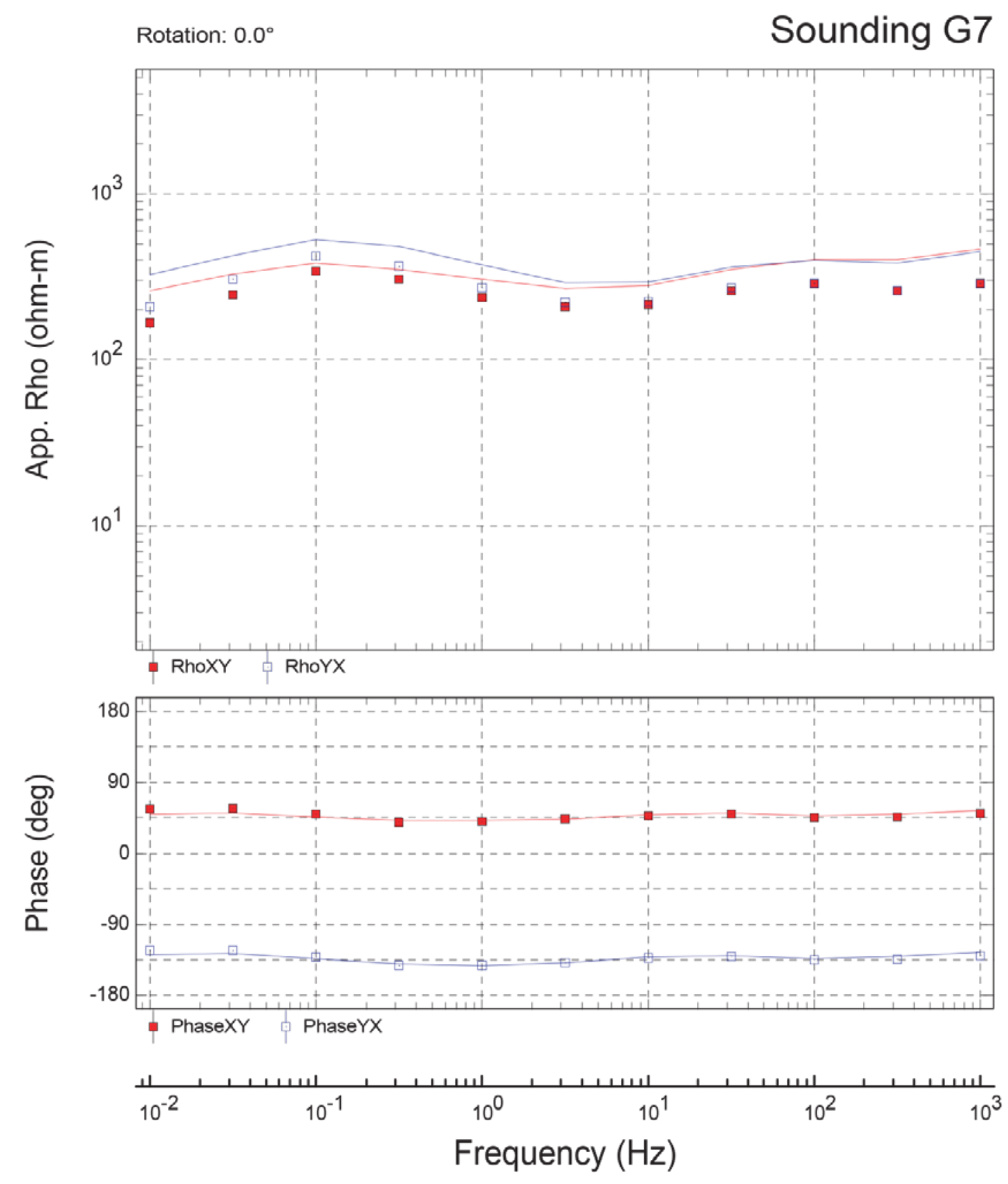


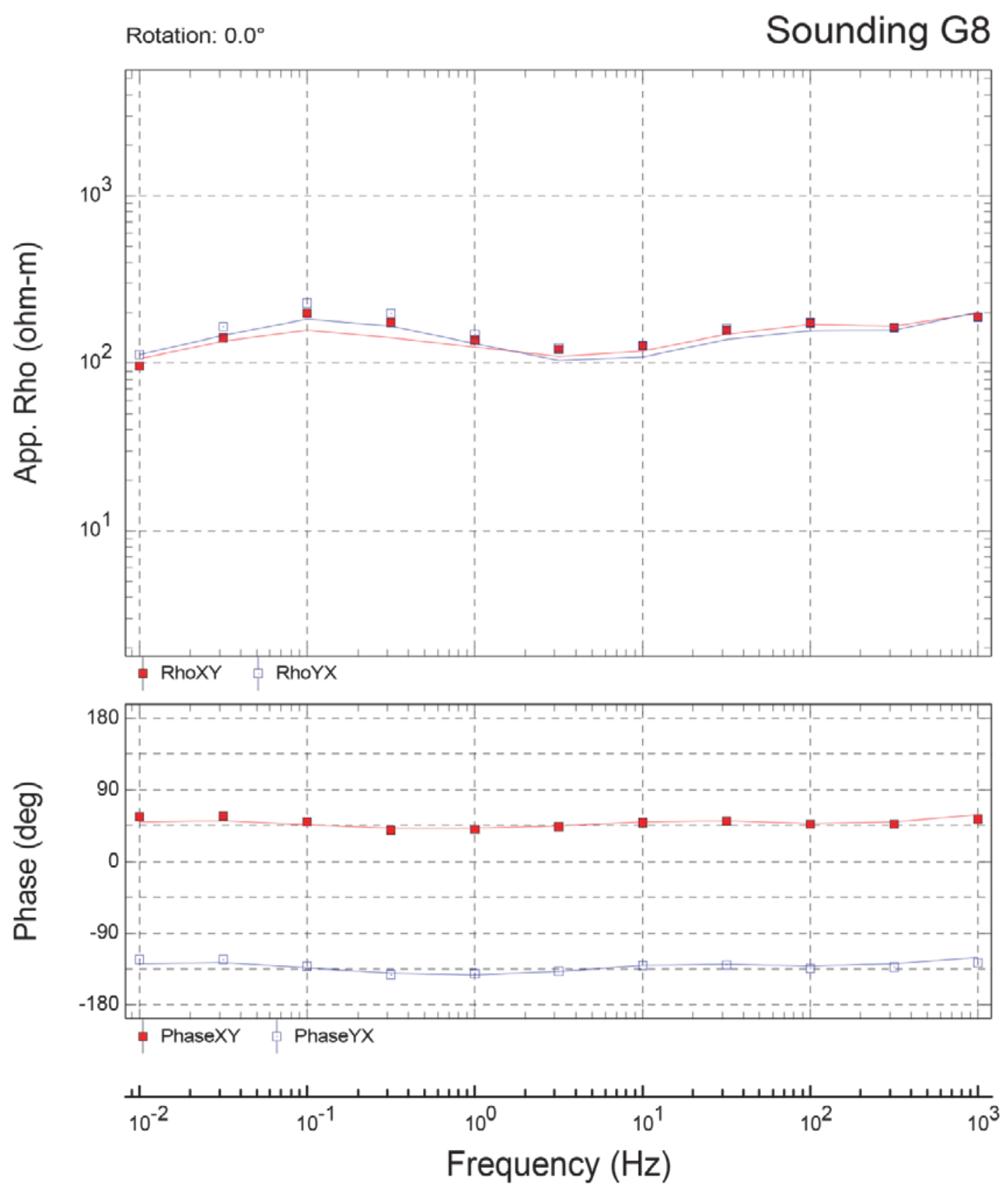




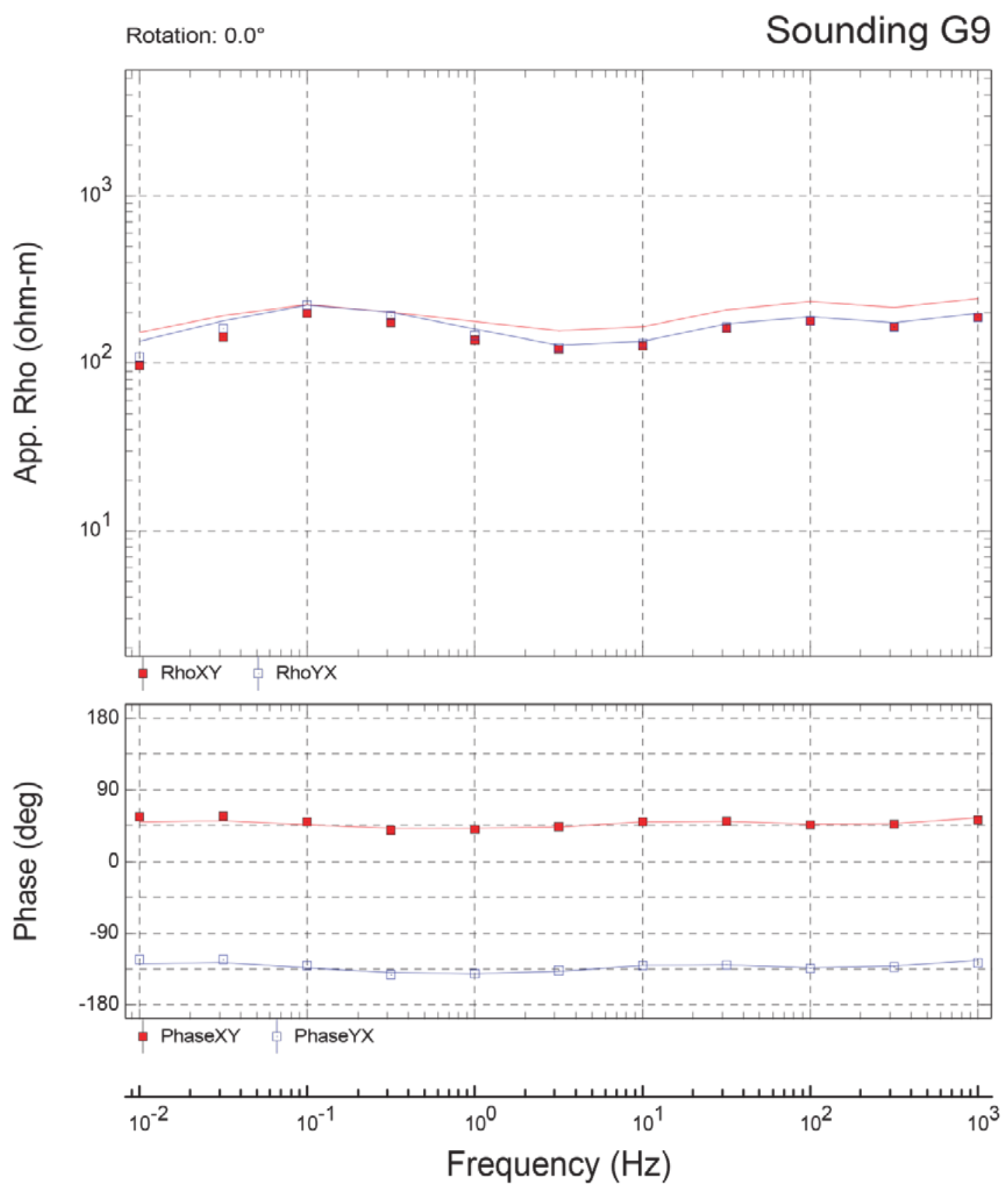




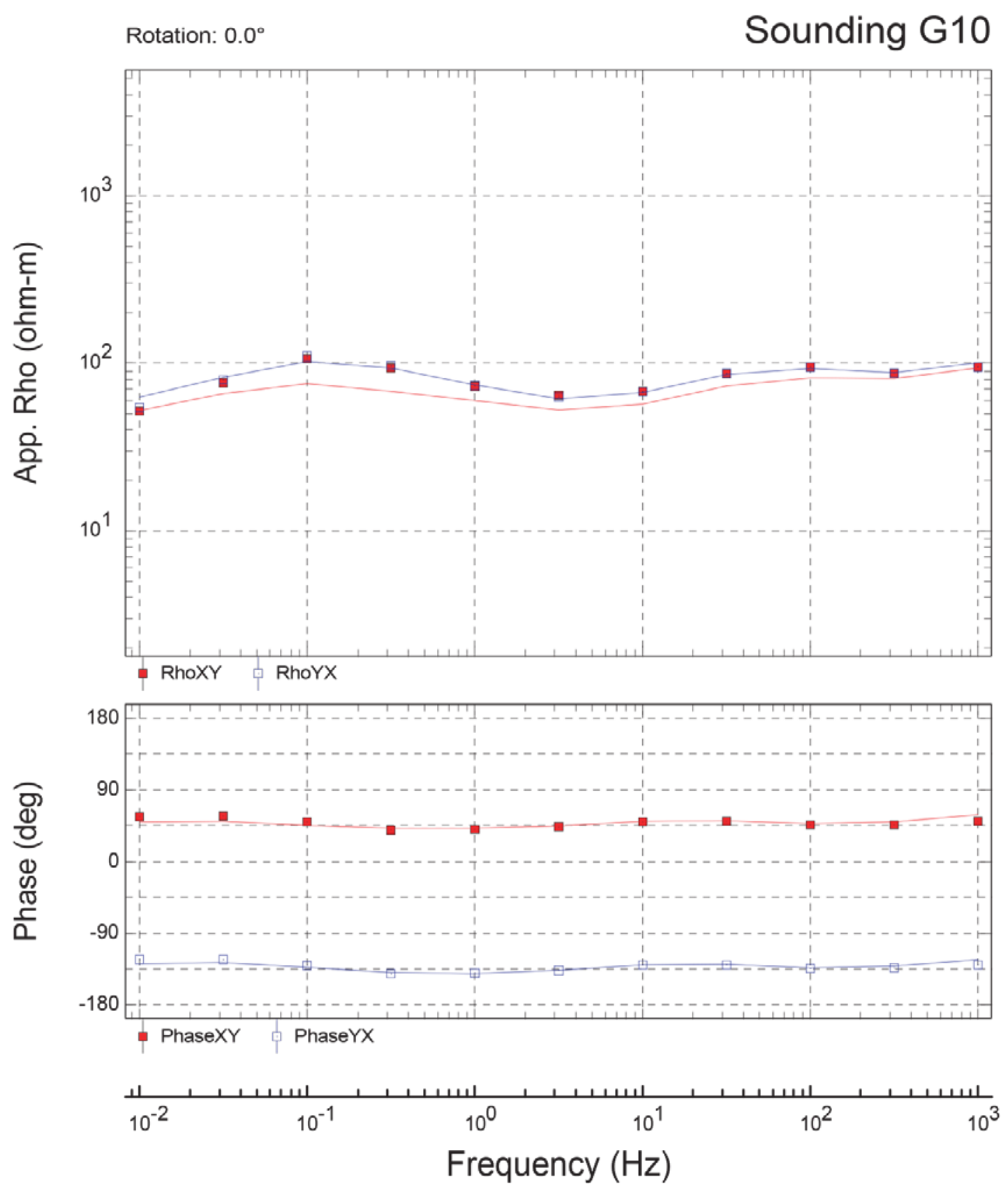




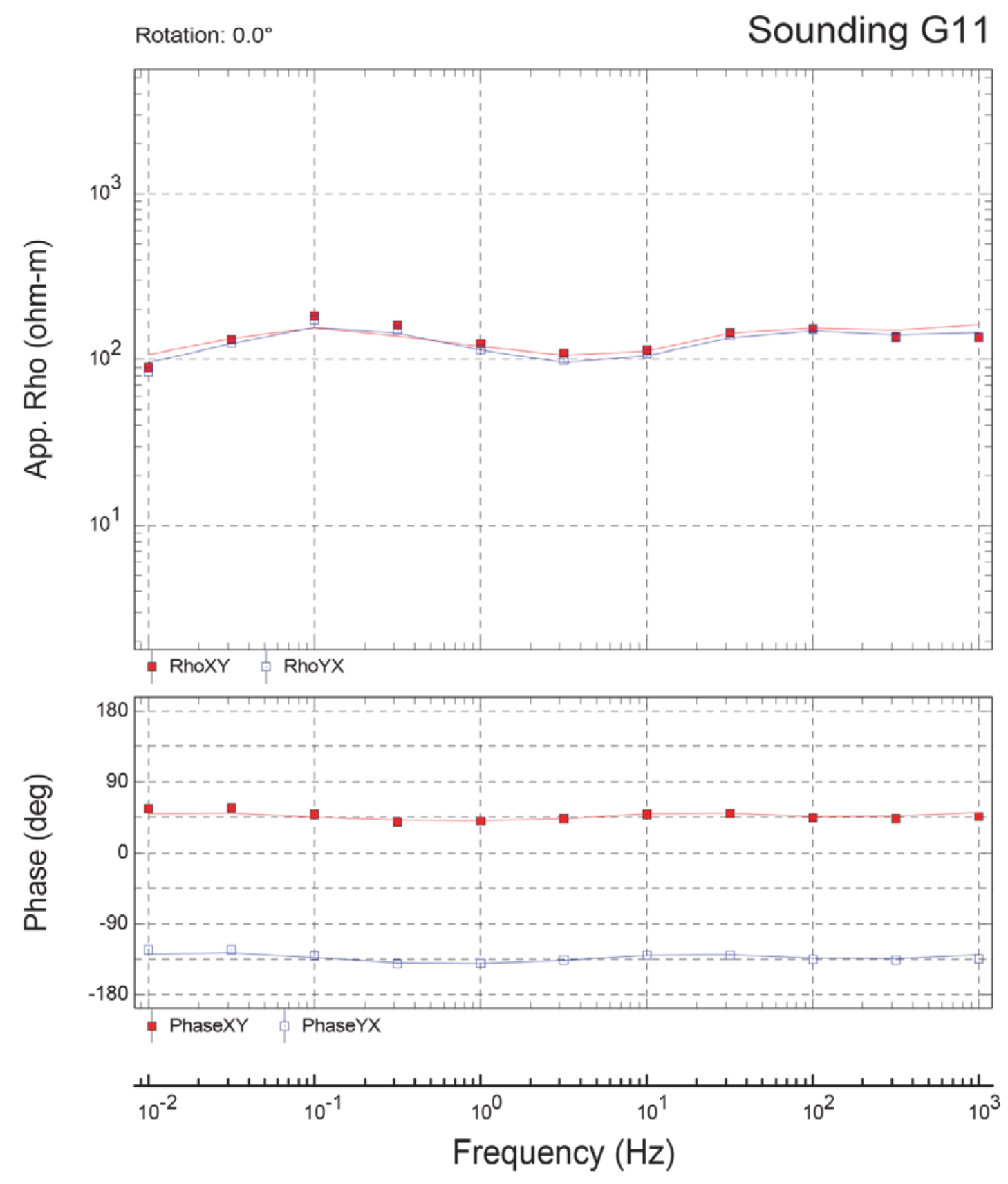




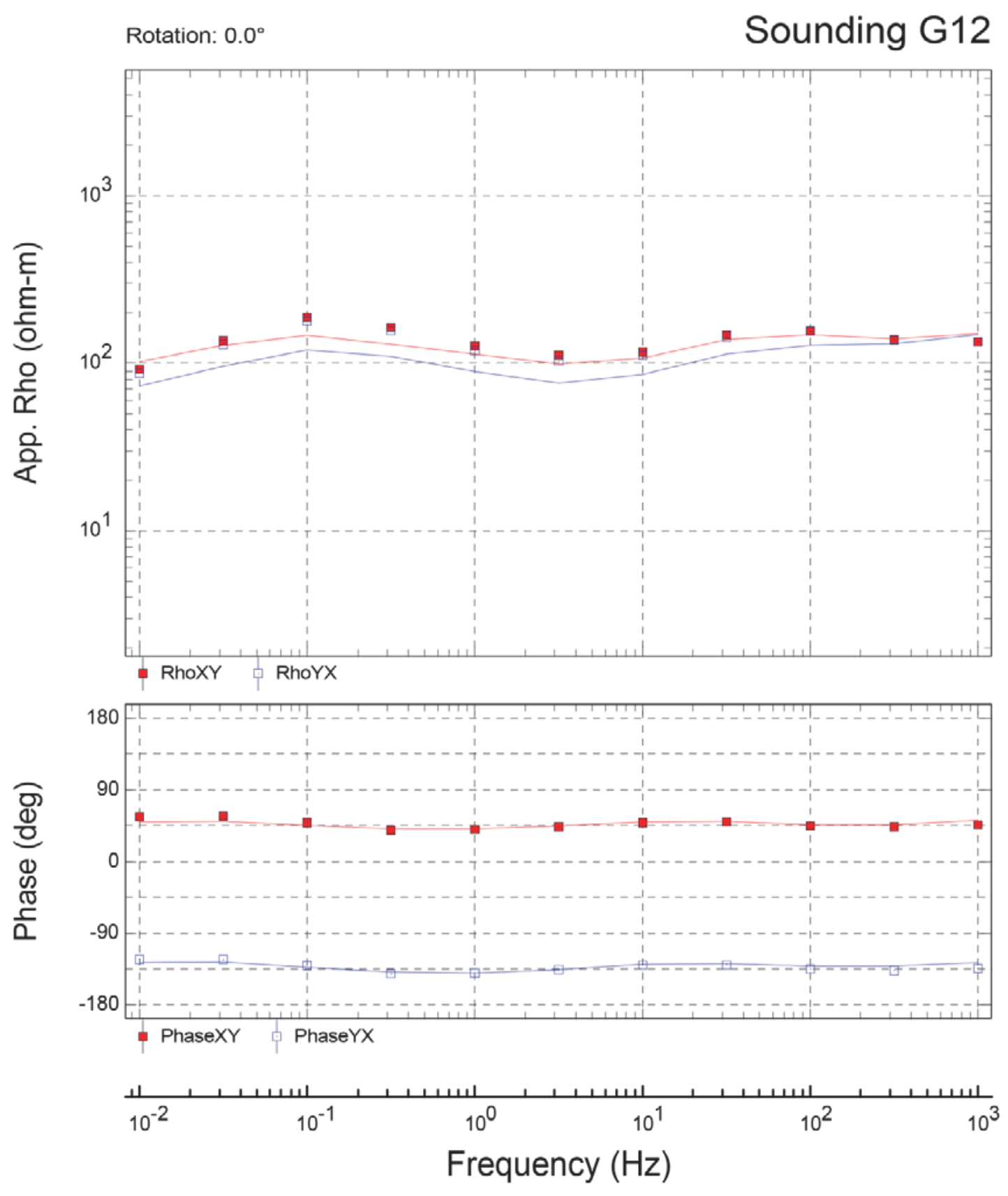



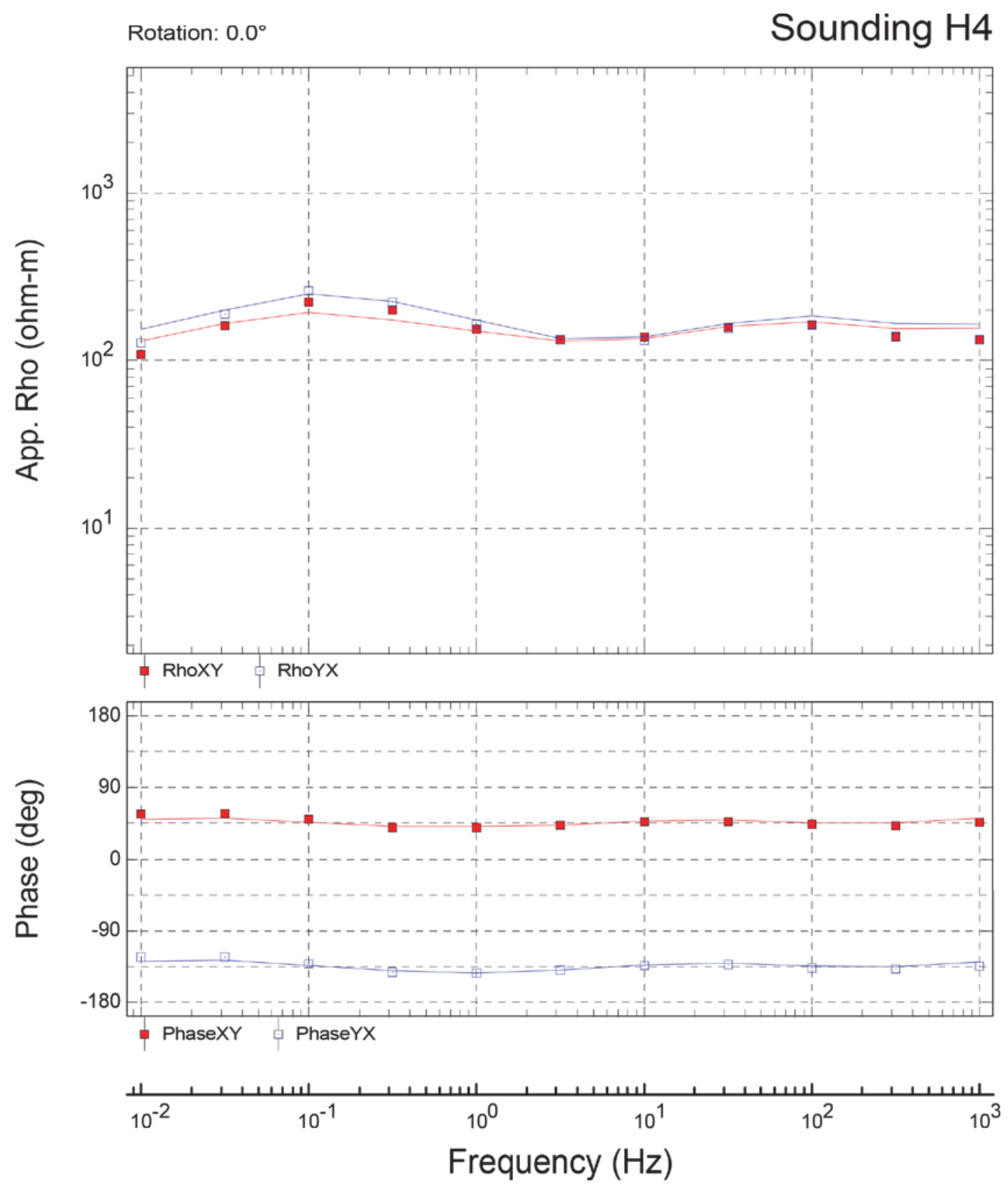

Figure 20. Soundings $\mathrm{H} 4-\mathrm{H} 12$. Pahute Mesa three-dimensional resistivity inversion data along profile $\mathrm{H}$. All other labels, symbols, and lines are as in figure 13. 

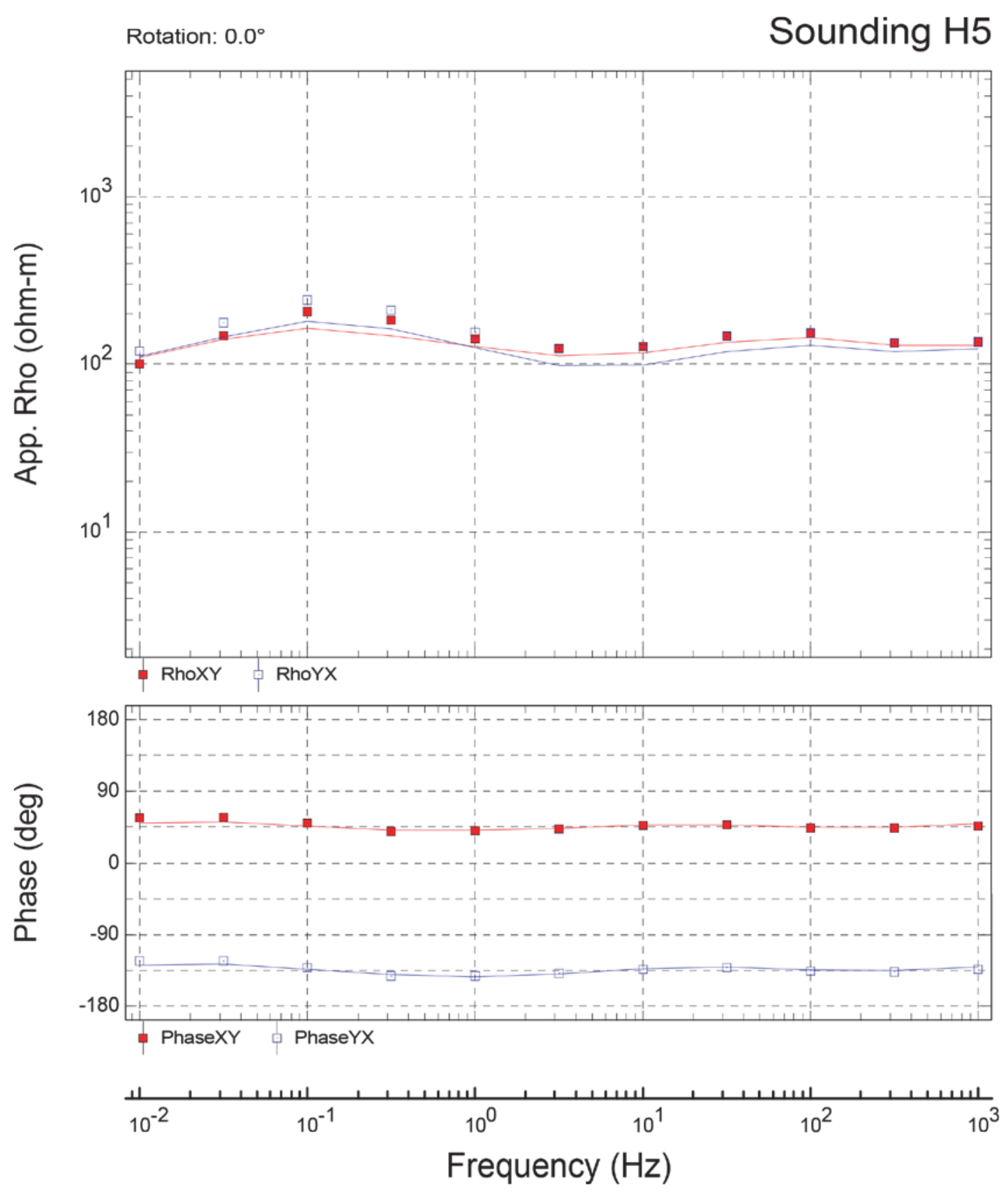

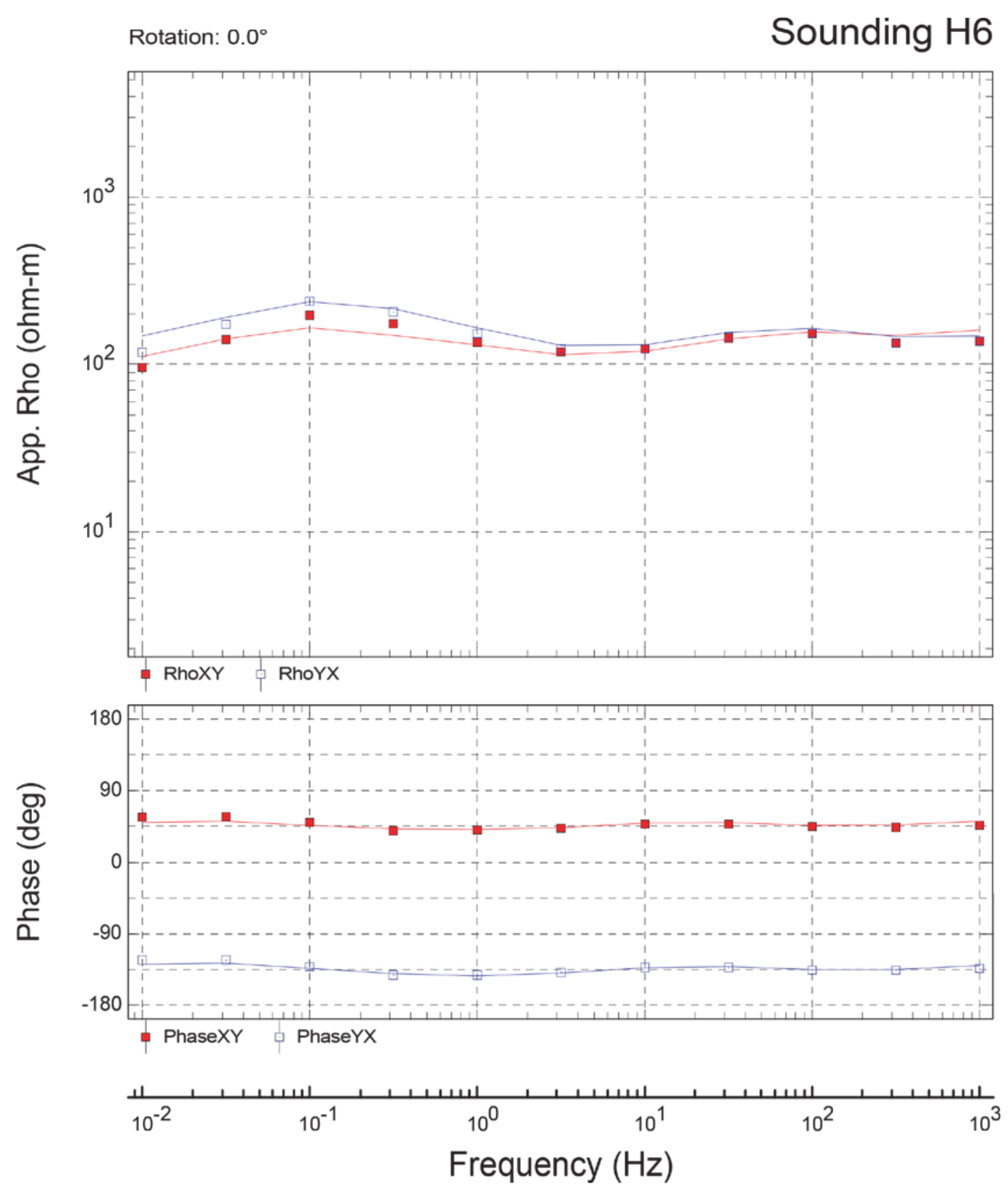

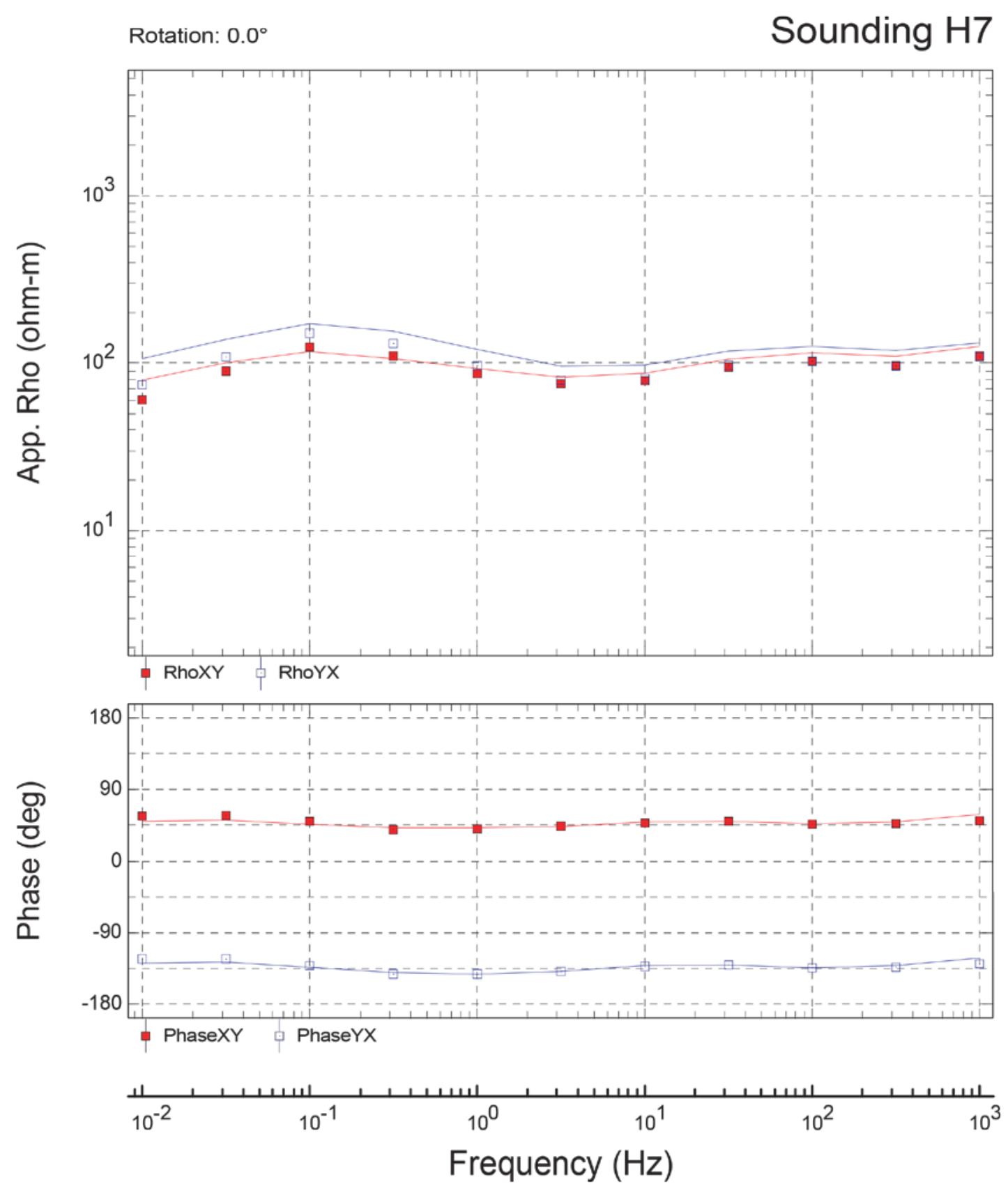

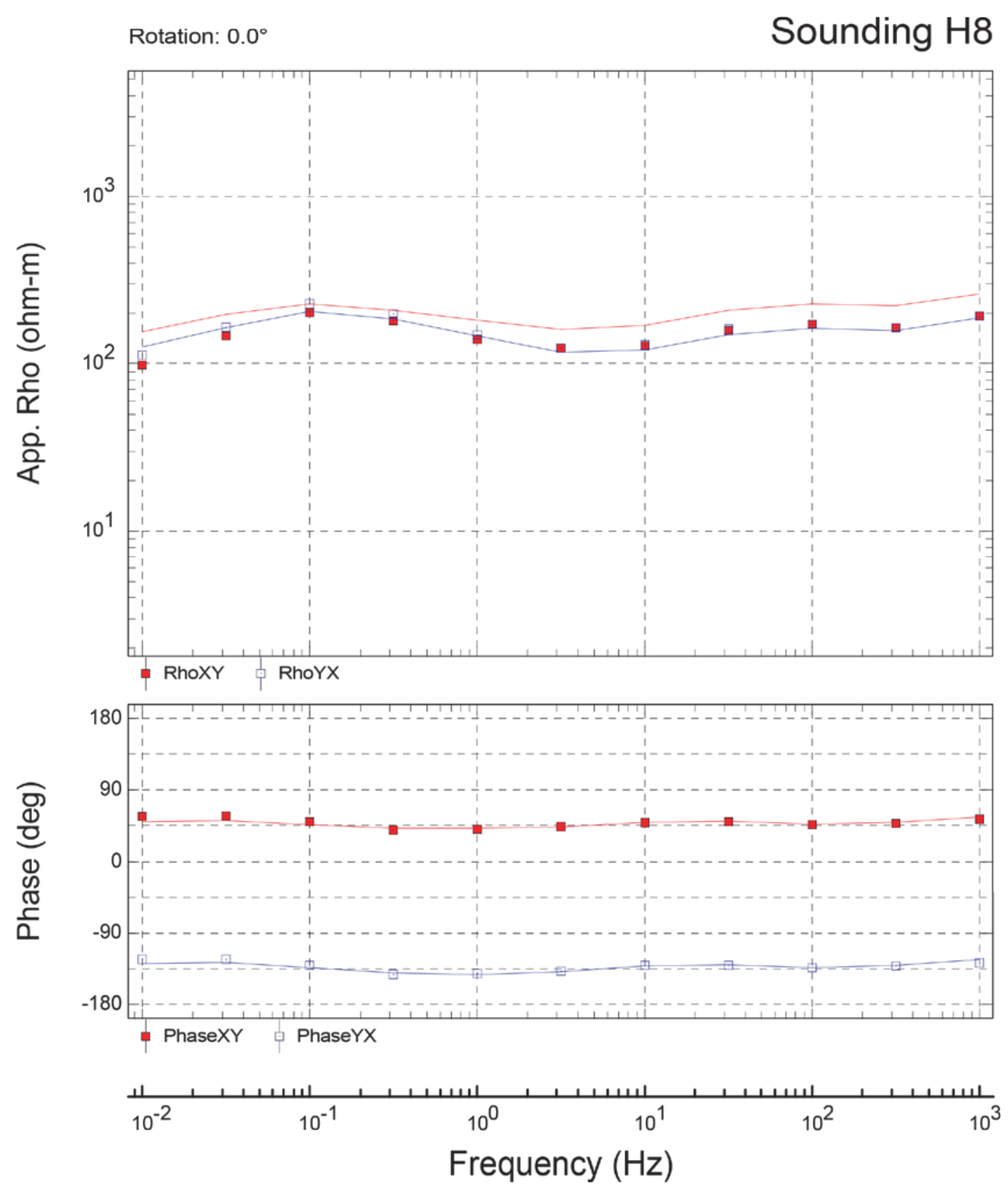

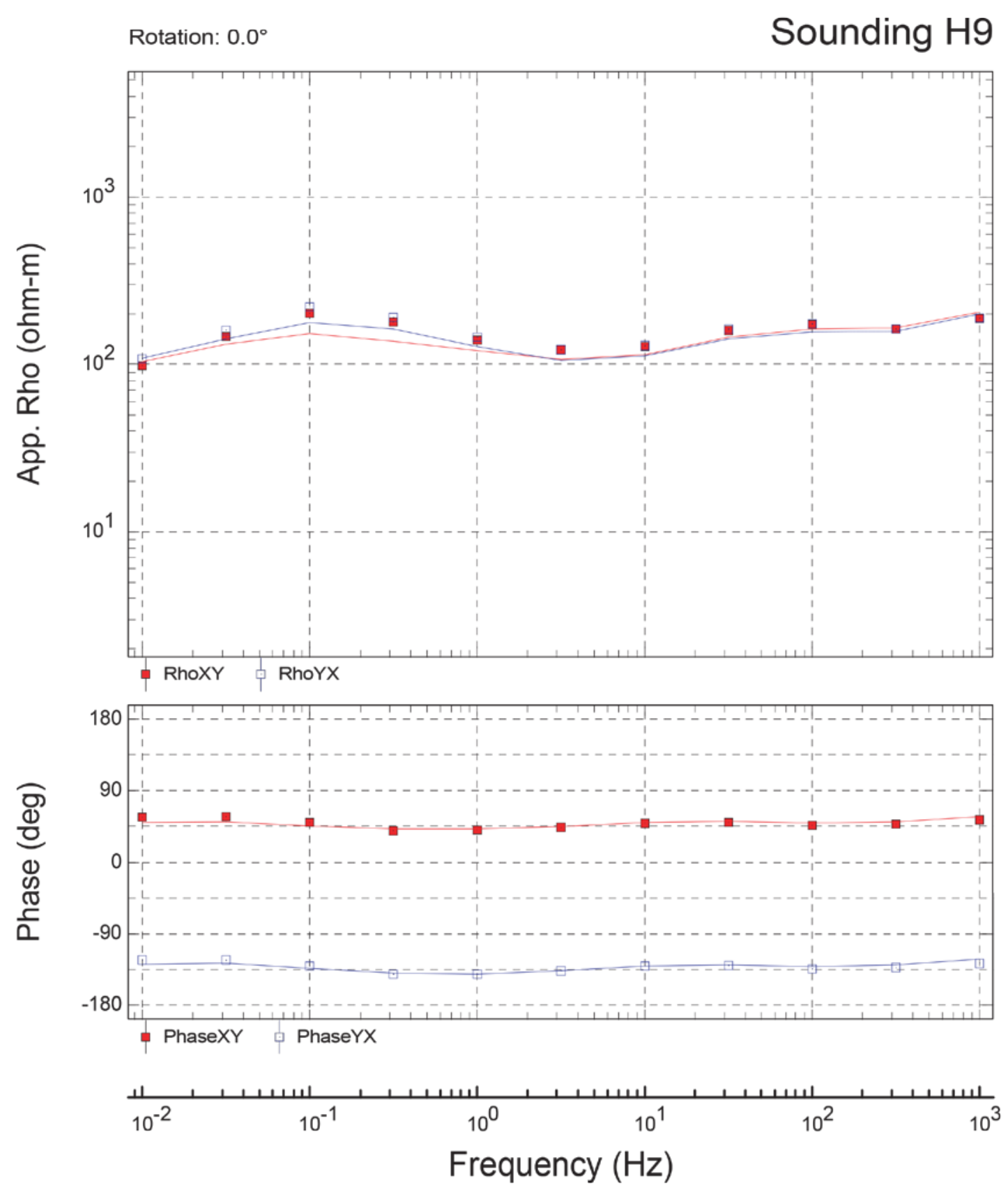

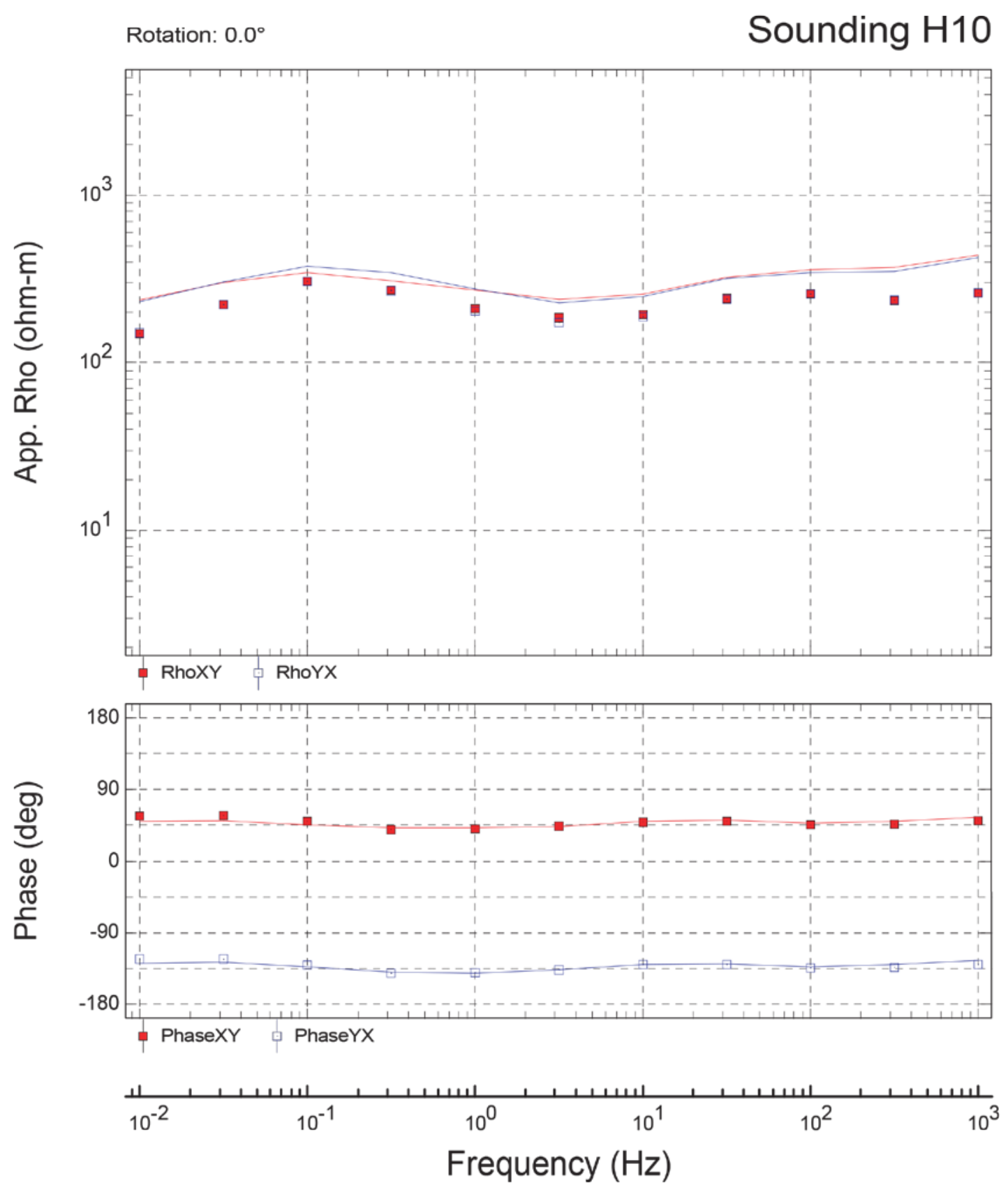

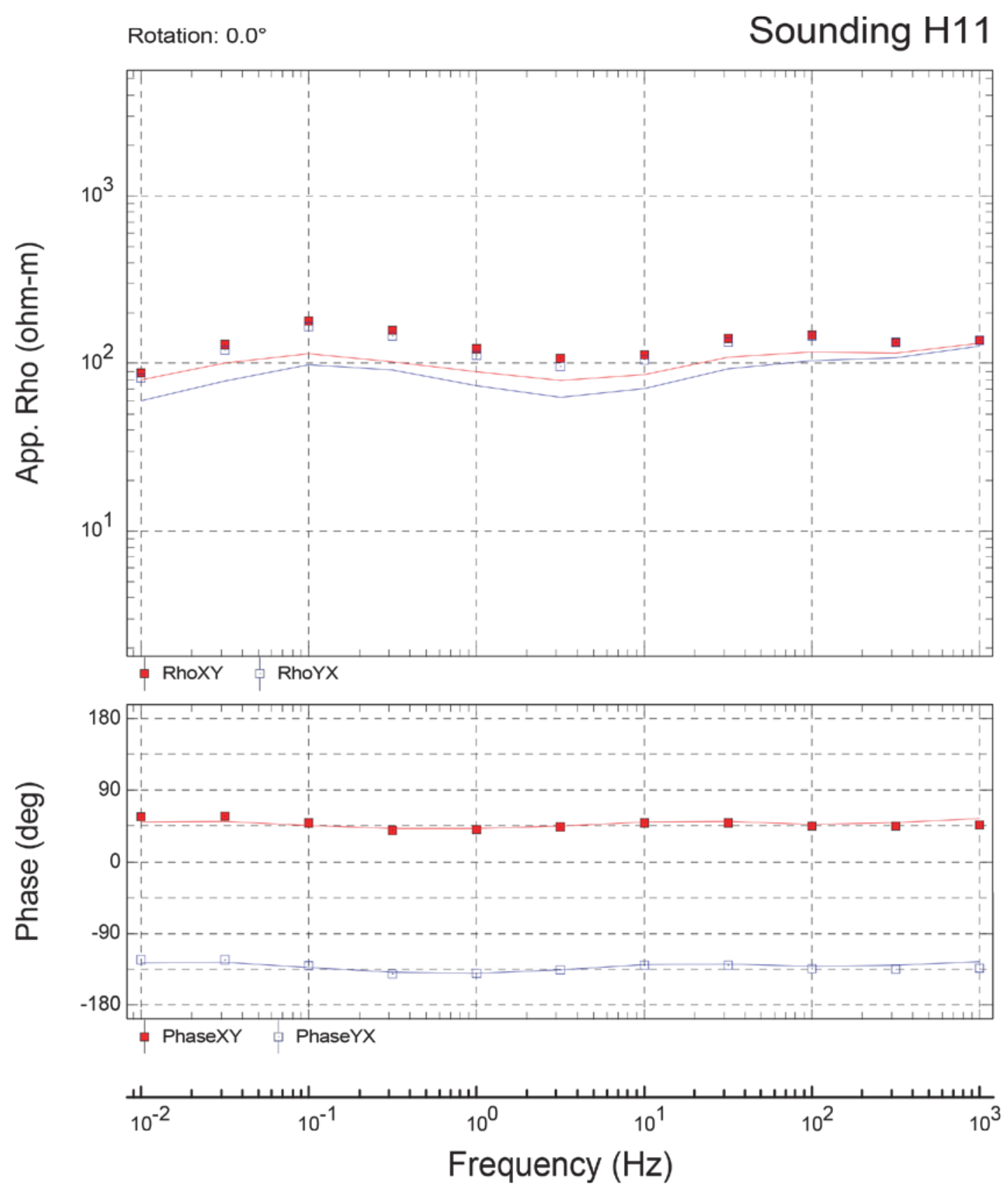

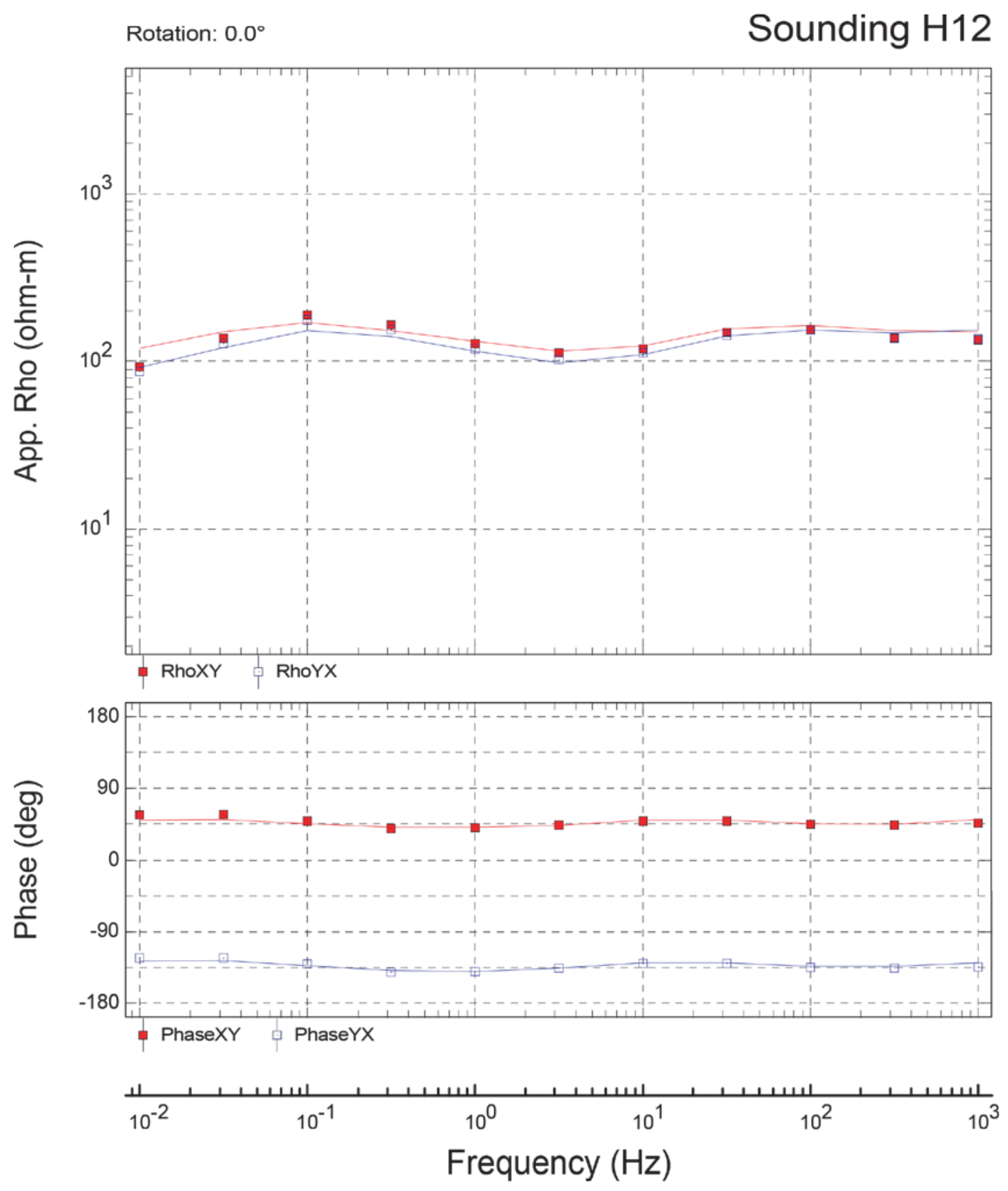

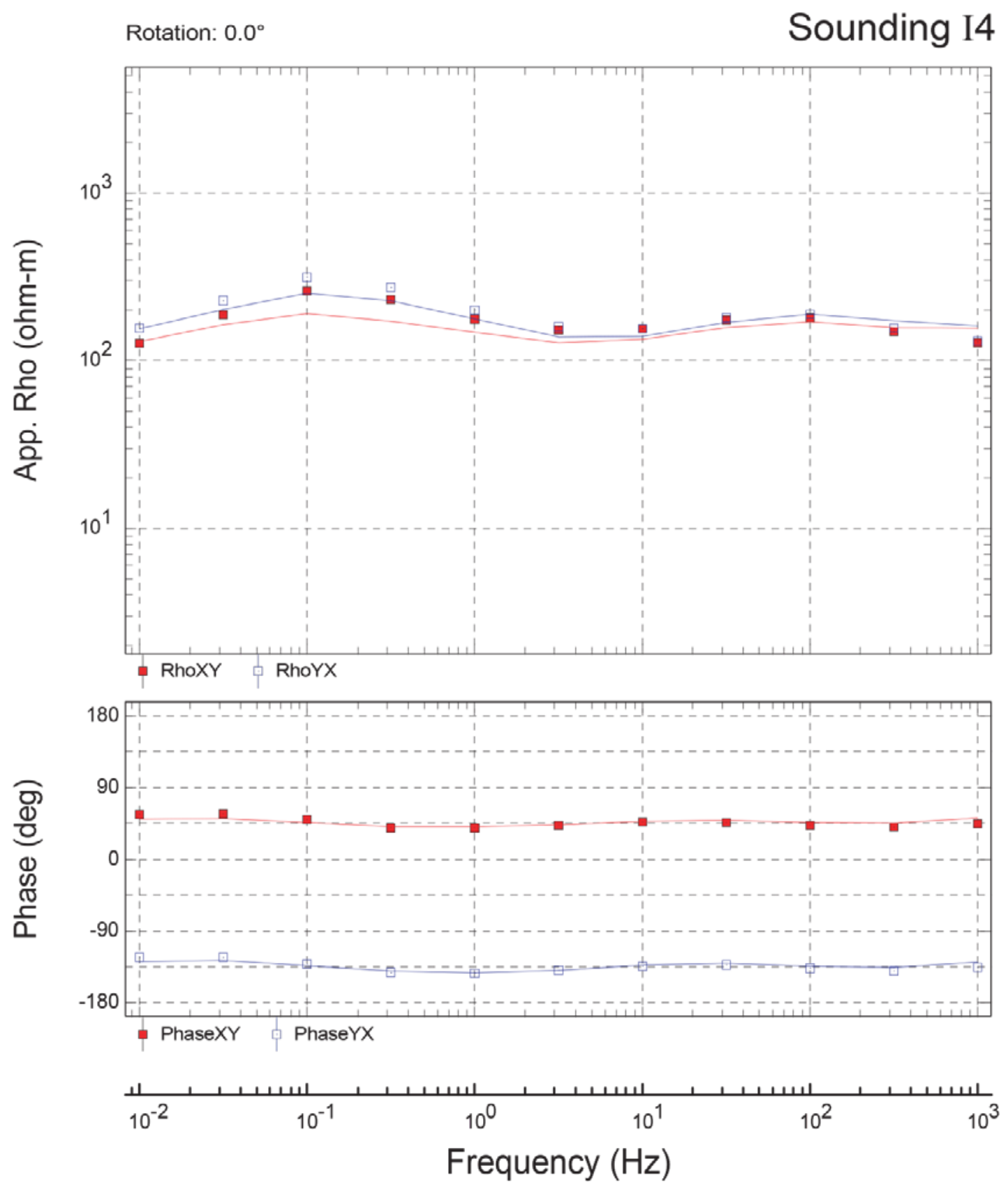

Figure 21. Soundings I4-I12. Pahute Mesa three-dimensional resistivity inversion data along profile I. All other labels, symbols, and lines are as in figure 13. 


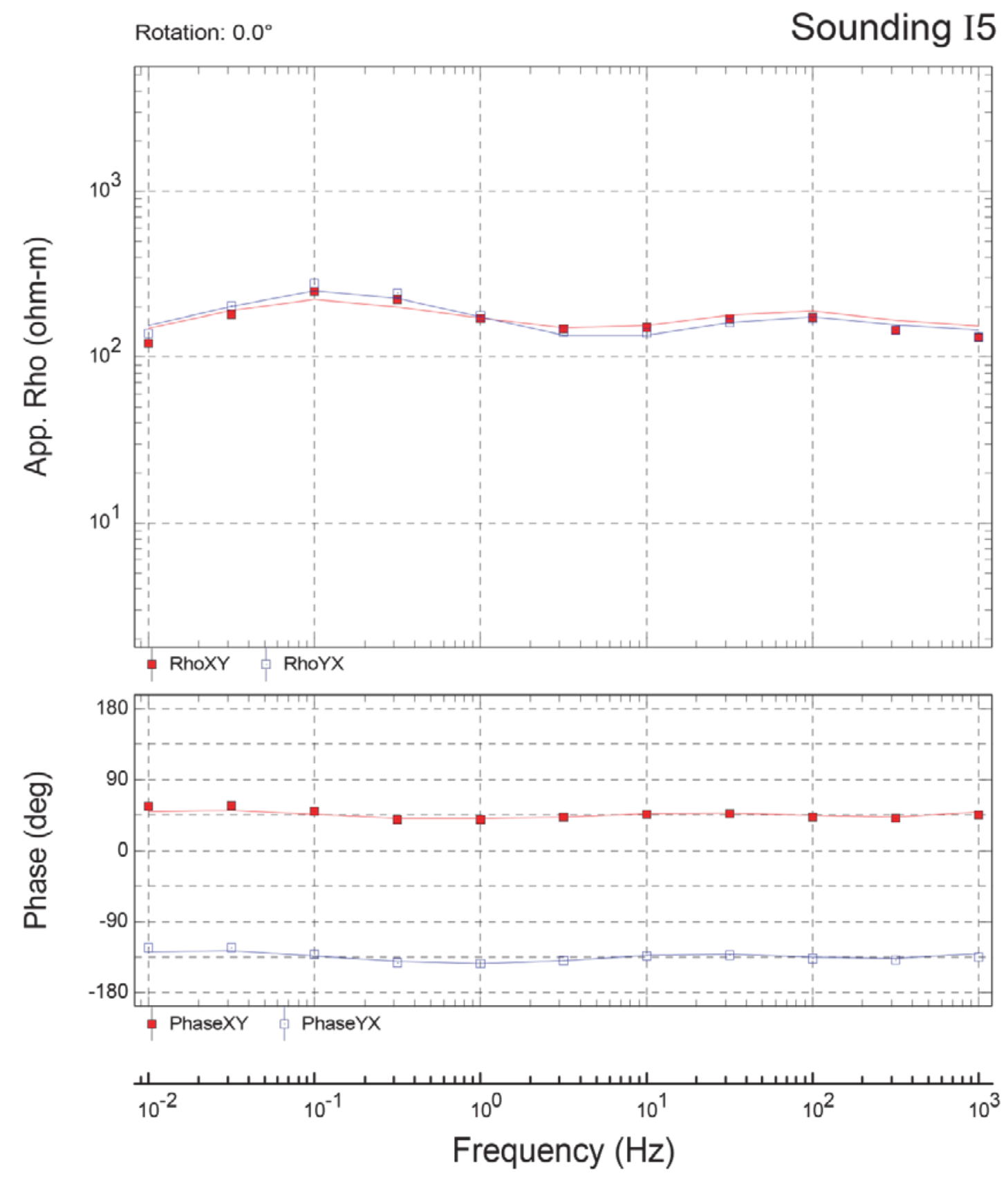




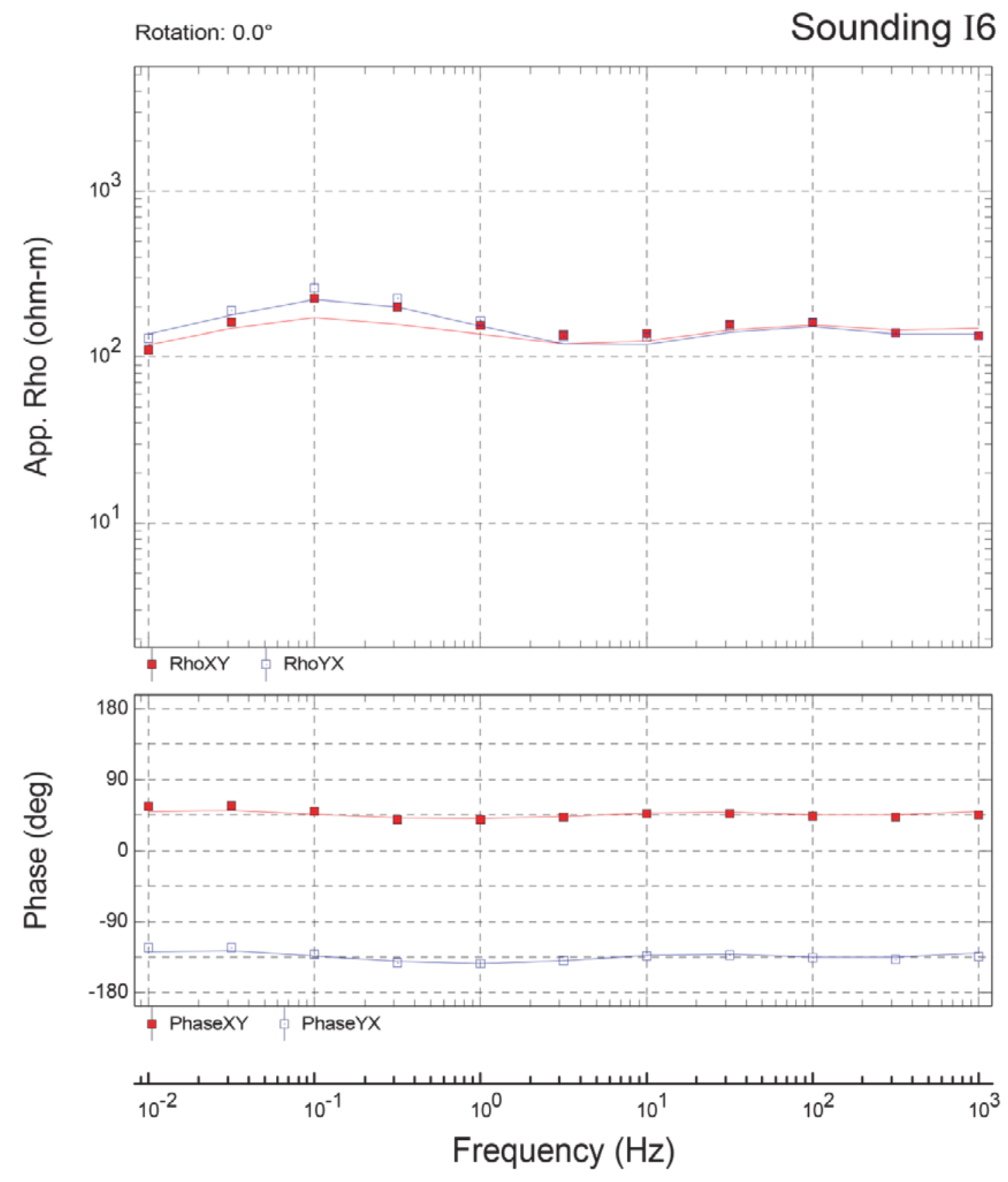




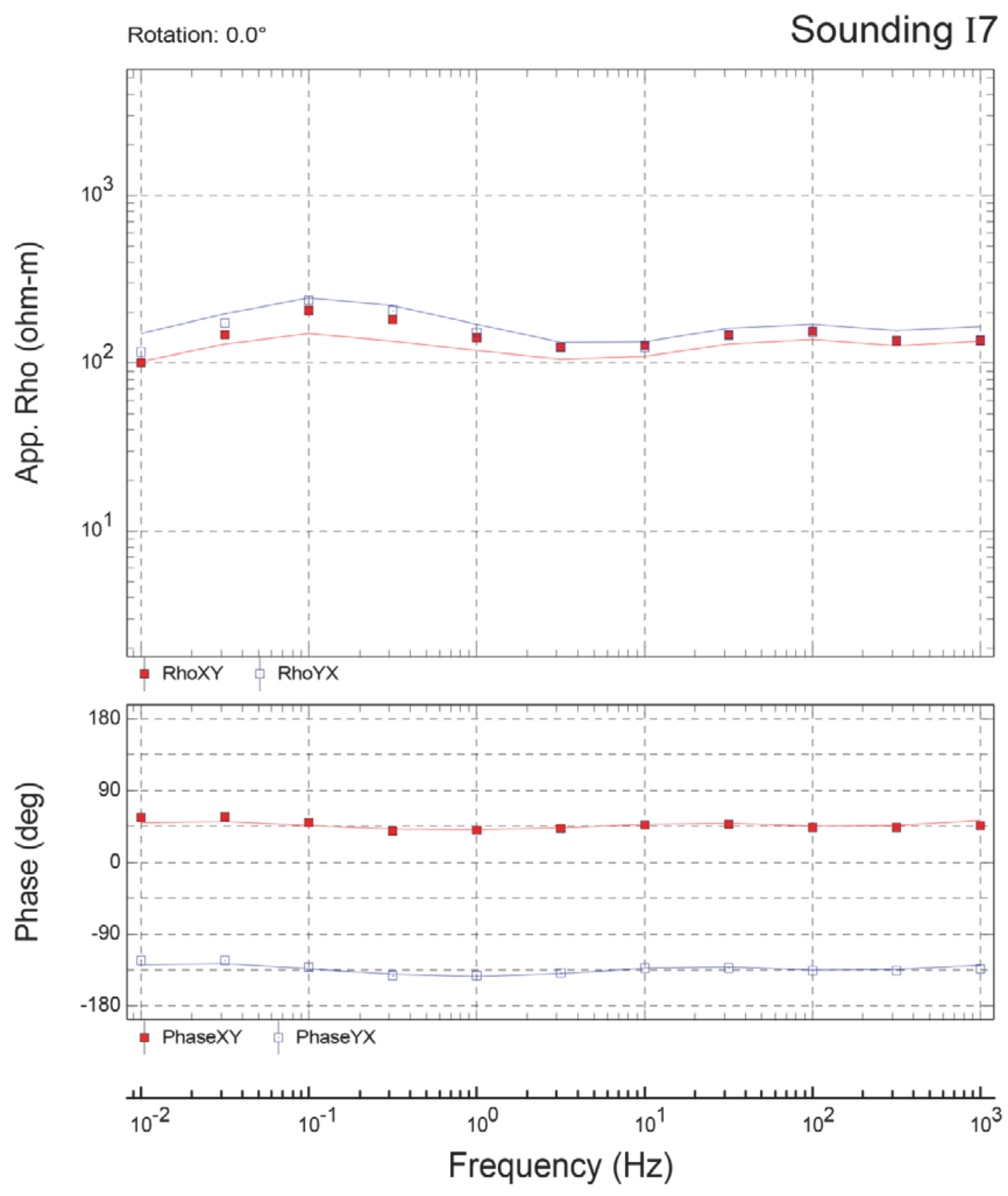




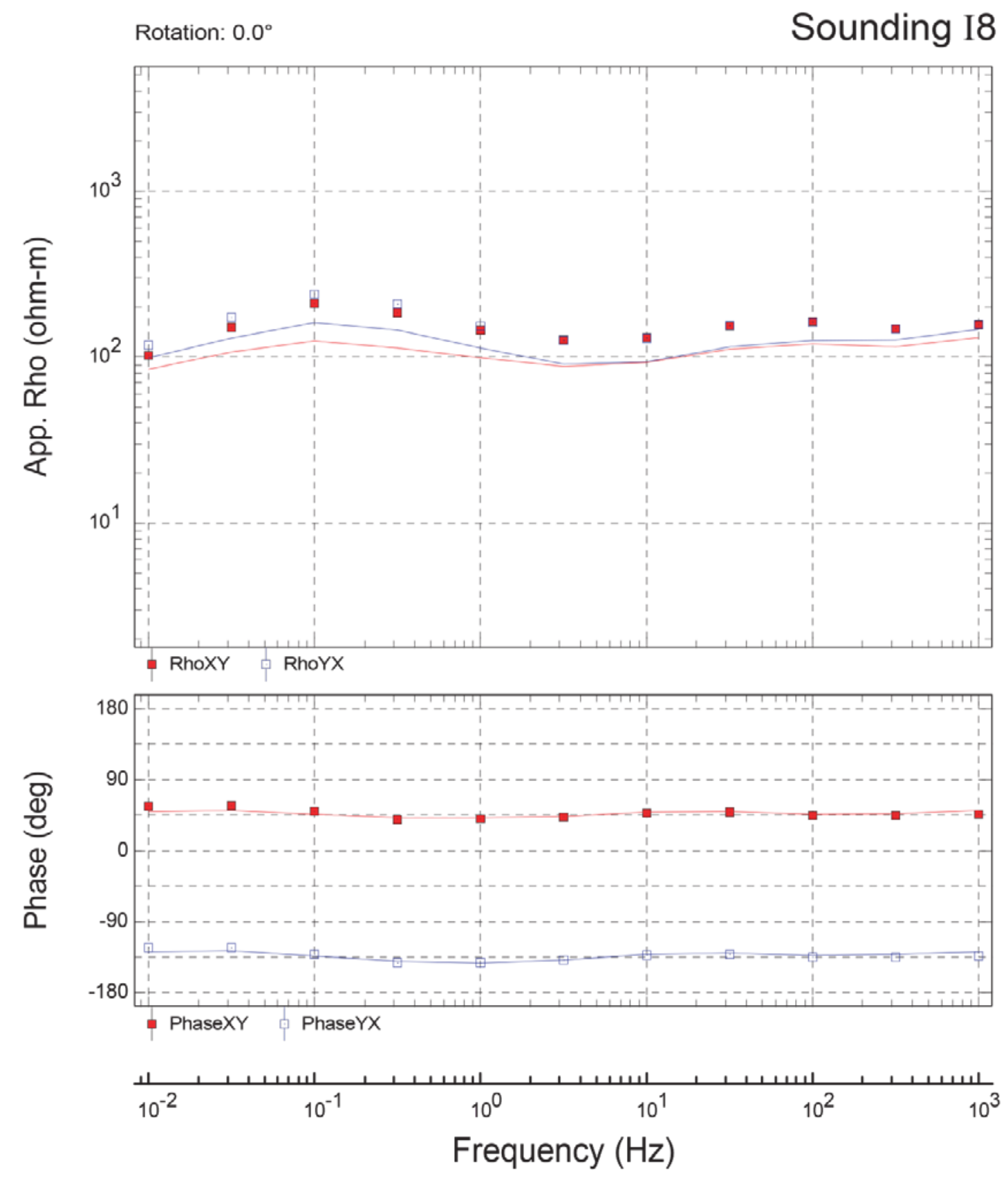




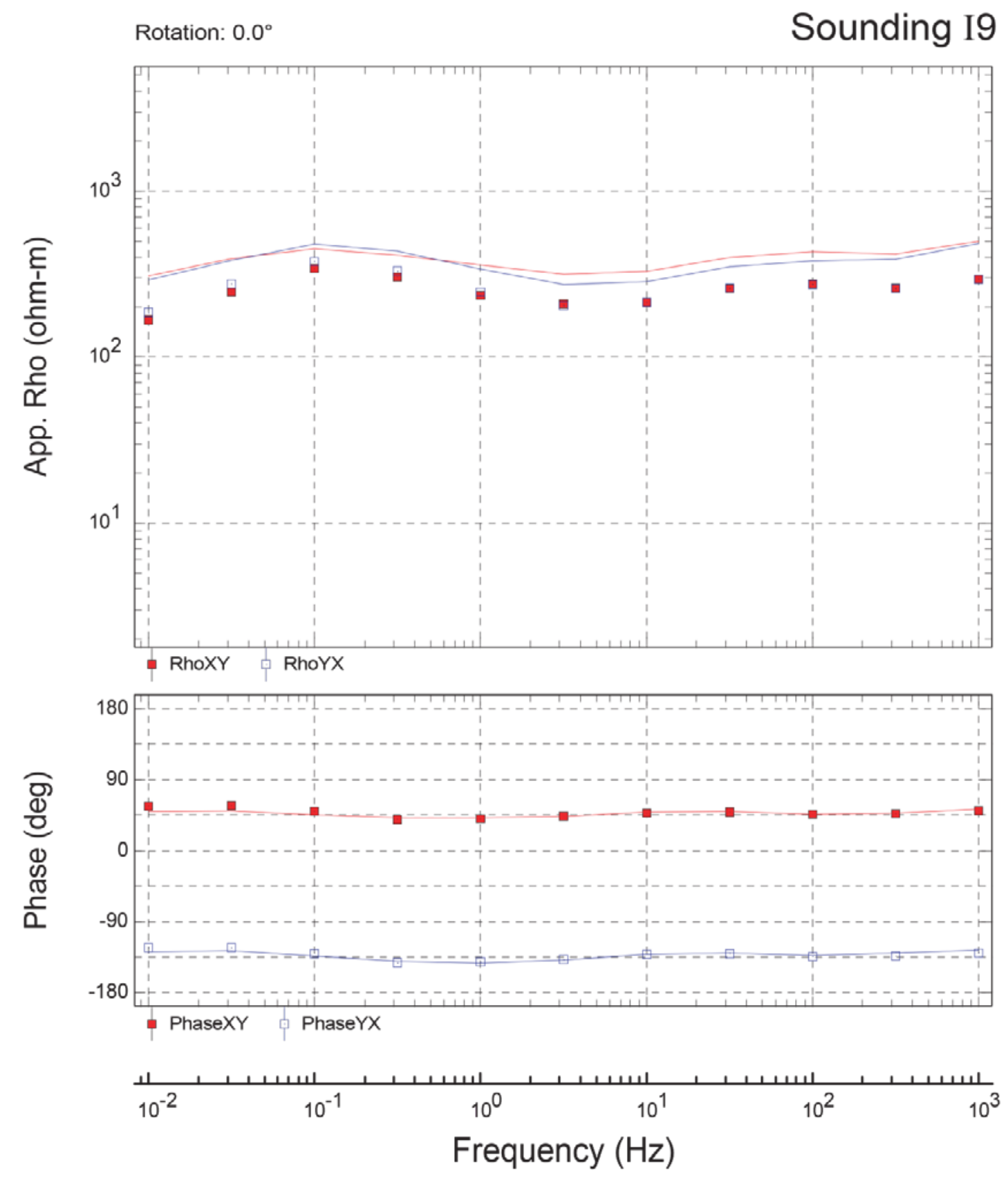




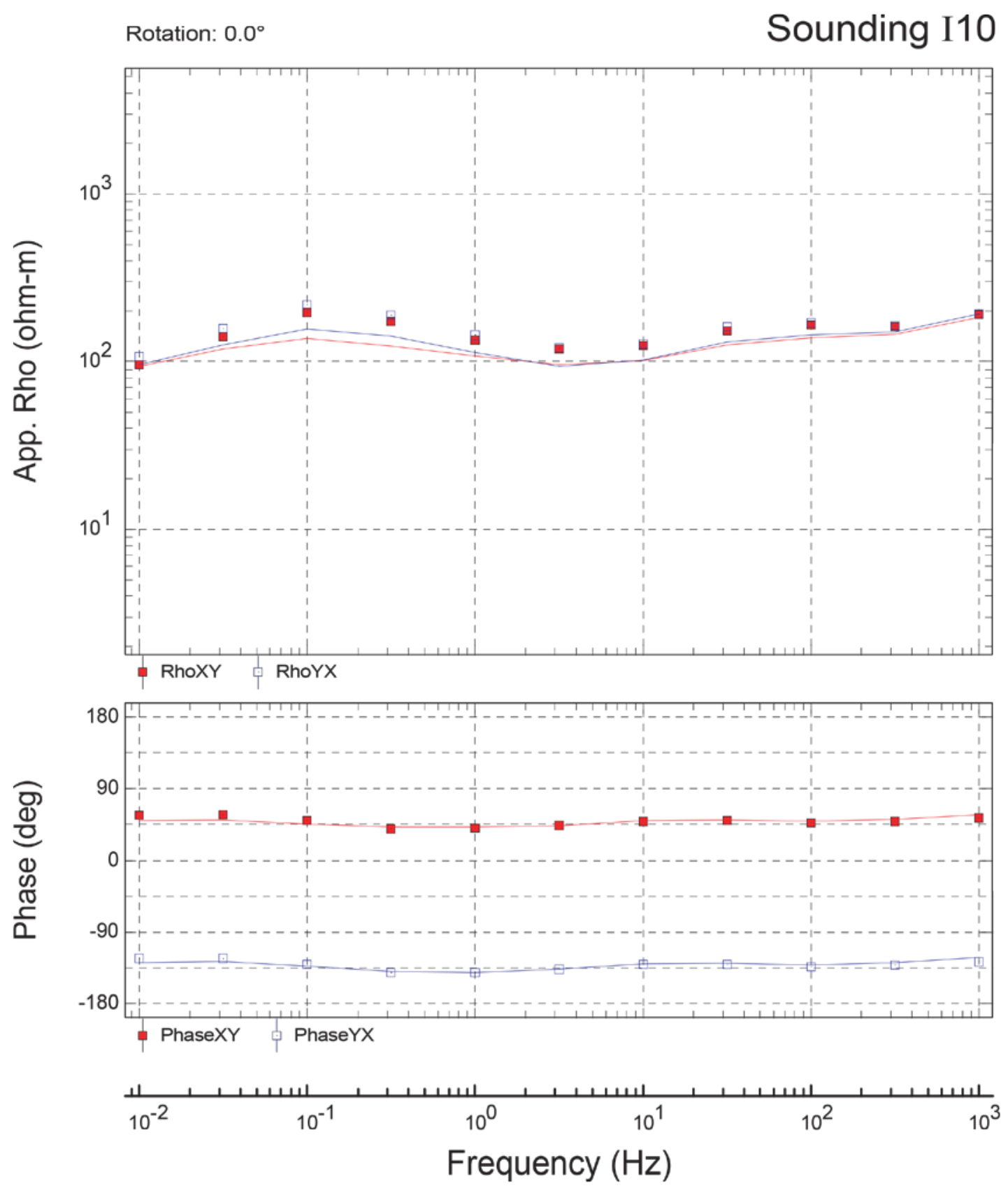



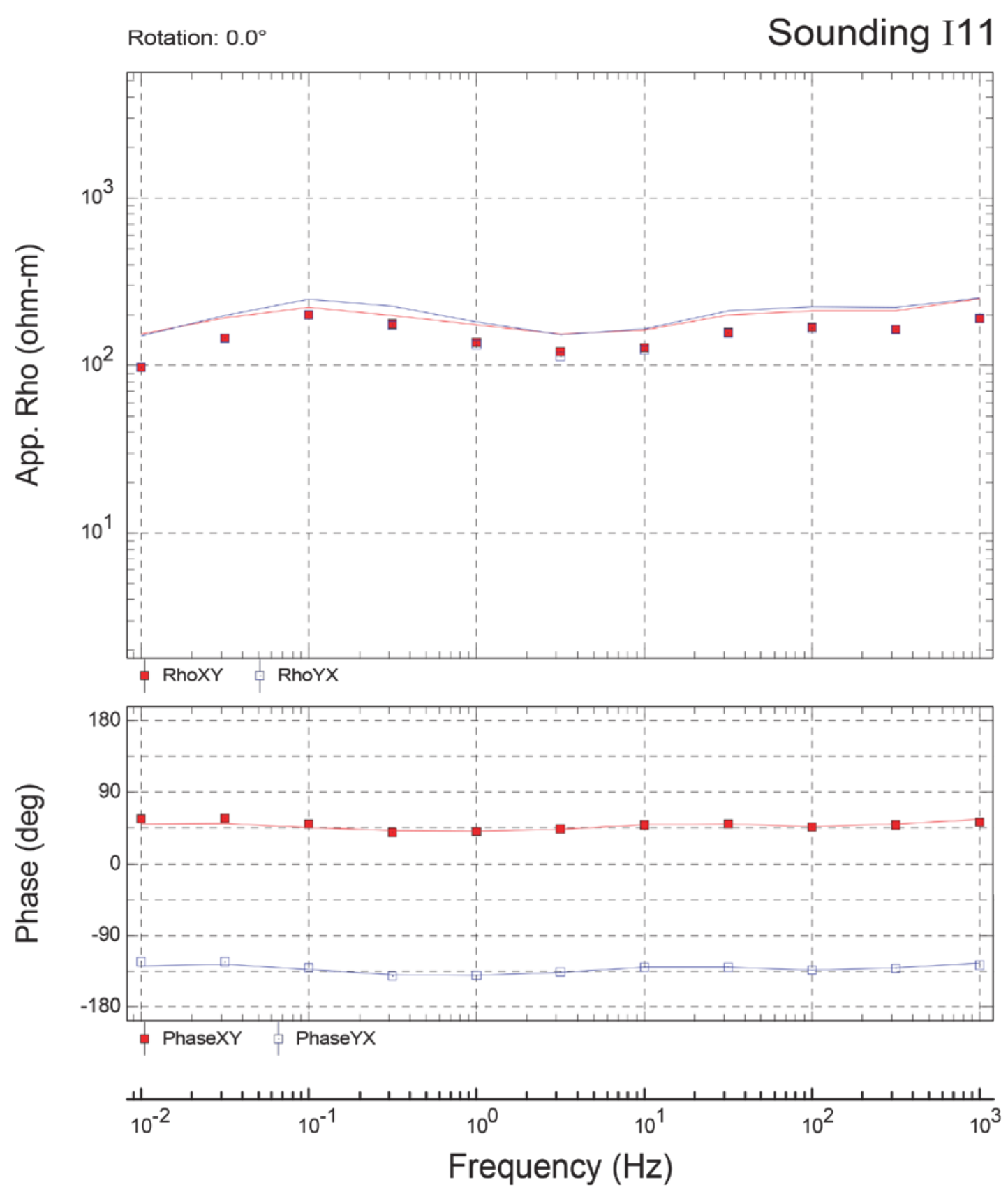


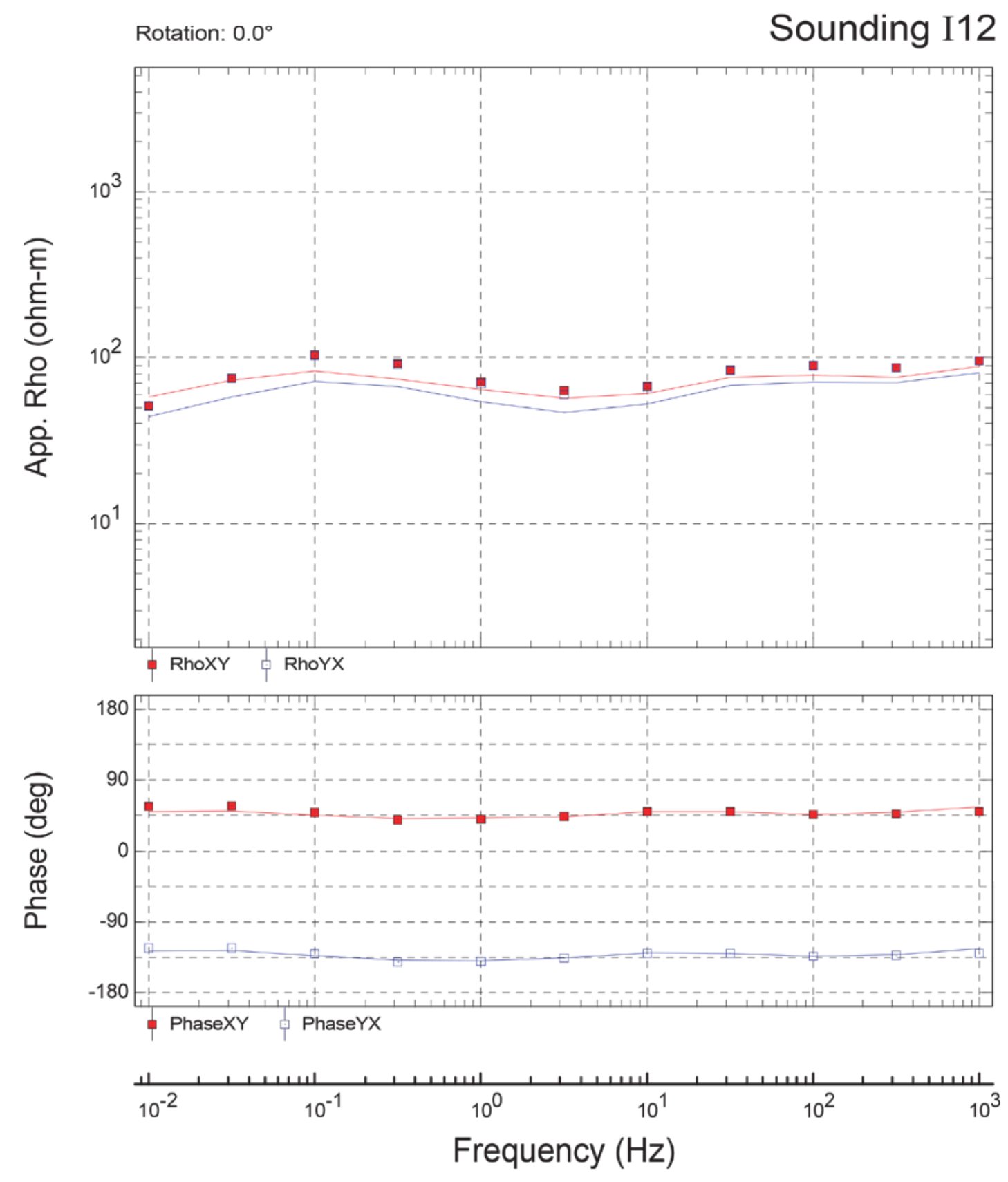

